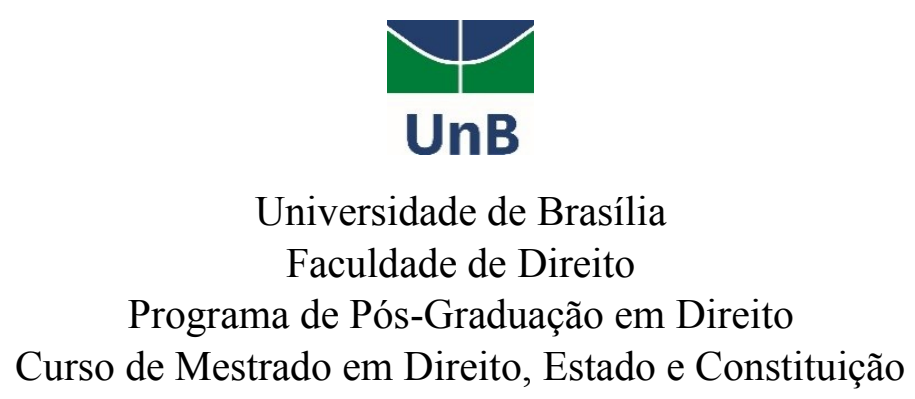

Universidade de Brasilia

Faculdade de Direito

Curso de Mestrado em Direito, Estado e Constituição

\title{
DIREITO, SOBERANIA E VASSALAGEM: As políticas do endividamento nas cortes constitucionais
}

\author{
João Gabriel Pimentel Lopes
}

Brasília

2015 
Universidade de Brasília

Faculdade de Direito

Programa de Pós-Graduação em Direito

Curso de Mestrado em Direito, Estado e Constituição

\title{
DIREITO, SOBERANIA E VASSALAGEM: As políticas do endividamento nas cortes constitucionais
}

\author{
João Gabriel Pimentel Lopes
}

Dissertação apresentada como requisito parcial de obtenção do título de Mestre em Direito no Programa de Pós-Graduação Stricto Sensu da Faculdade de Direito da Universidade de Brasília UnB, na área de concentração "Direito, Estado e Constituição", linha de pesquisa "Constituição e Democracia".

Orientador: Prof. Dr. Alexandre Araújo Costa

Brasília 


\title{
DIREITO, SOBERANIA E VASSALAGEM: As políticas do endividamento nas cortes constitucionais
}

\author{
João Gabriel Pimentel Lopes
}

\section{FICHA DE AVALIAÇÃO}

Após sessão pública de defesa desta dissertação de mestrado, o candidato foi considerado aprovado pela banca examinadora.

Prof. Dr. Alexandre Araújo Costa

(Orientador - Faculdade de Direito - UnB)

Prof. Dr. George Rodrigo Bandeira Galindo

(Membro interno - Faculdade de Direito - UnB)

Prof. Dr. Frederico Barbosa da Silva

(Membro externo - Instituto de Pesquisa Econômica Aplicada)

Profa. Dra. Loussia Penha Musse Félix

(Suplente - Faculdade de Direito - UnB) 


\section{RESUMO}

Este trabalho consiste em uma pesquisa exploratória com o objetivo de delimitar categorias jurídicas relevantes e promover um aprofundamento inicial sobre os julgamentos de cortes constitucionais que envolvem o tema do endividamento público argentino após a crise do início dos anos 2000, mediante a análise dos diversos discursos críticos das referidas decisões. Nos casos que constituem o objeto da pesquisa, verifica-se uma contínua tensão entre os poderes da soberania e os poderes dos contratos, o que leva a uma discussão sobre o posicionamento dos Estados como entidades negociantes na arena das finanças. Tal tensão pode ser localizada historicamente no contexto de mudanças sociais, políticas e econômicas que deslocaram os discursos sobre o exercício de poder de uma dimensão imperial centrada na razão de Estado para uma outra centralizada em uma governamentalidade centrada em figuras de gestão. O direito constitucional, especialmente por intermédio da figura do rule of law, surge, nesse contexto, como elemento legitimador das dominações dessa quadra histórica. Seu catalisador principal na segunda metade do século $\mathrm{XX}$, as cortes constitucionais não escaparam dessa mobilização. $\mathrm{O}$ tratamento dado à questão do endividamento argentino torna-se um elemento indiciário da questão, de modo que decisões diversas daquelas que favorecem tal forma de governamentalidade somente são possíveis mediante o apelo a uma possível suspensão da ordem. Essa suspensão, entretanto, é facilmente afastada pela emergência constitucionalmente legitimada dos discursos de imperiais de expansão econômica, a sinalizar a conformação jurídica de uma relação de suserania e vassalagem entre credores tutelados por suas ordens jurídicas nacionais - ocupantes da posição dominadora - e países endividados - transformados em vassalos da ordem econômica internacional. 


\section{RESUMEN}

Esta investigación exploratoria tiene como objetivo delimitar y promover una profundización inicial de las categorías jurídicas relevantes que impregnan los juicios emitidos por cortes constitucionales sobre el tema de la deuda pública argentina tras la crisis que ocurrió en principios de los años 2000, mediante el análisis de los diversos discursos críticos de estas decisiones. En los casos investigados, se verificó tensión continua entre los poderes de la soberanía y los poderes de los contratos, lo que conduce a una discusión sobre la posición de los Estados como actores en la arena de las finanzas. Esta tensión se ubica históricamente en el contexto de los cambios sociales, políticos y económicos que dislocaron el eje de los discursos sobre el ejercicio del poder, inicialmente ajustado a una dimensión imperial centrada en la razón del Estado, y que ahora se orienta en una idea de gubernamentalidad centrada en figuras de gestión. El derecho constitucional, especialmente a través de la figura del rule of law, aparece en este contexto como elemento que legitima las dominaciones en ese cuadro histórico. Su principal catalizador en la segunda mitad del siglo XX, las cortes constitucionales no han escapado a esta movilización. El tratamiento de la deuda argentina es un elemento indiciario de los cambios en el eje discursivo, escenario en el cual la adopción de decisiones diversas de las que favorecen esta forma de gubernamentalidad solamente es posible haciendo apelo a una potencial suspensión del orden. Esa suspensión, sin embargo, es fácilmente retirada por la emergencia constitucionalmente legitimada de los discursos imperiales de expansión económica, señalando la conformación jurídica de una relación de señorío y vasallaje entre acreedores protegidos por sus ordenamientos jurídicos nacionales - ocupantes de posición dominante - y los países endeudados - convertido en vasallos del orden económico internacional. 
Tú no puedes comprar el viento

Tú no puedes comprar el sol

Tú no puedes comprar la lluvia

Tú no puedes comprar el calor

Tú no puedes comprar las nubes

Tú no puedes comprar los colores

Tú no puedes comprar mi alegría

Tú no puedes comprar mis dolores

(“Latinoamérica" - Rafael Arcaute) 


\title{
AGRADECIMENTOS
}

\author{
Mas meu coração só tem amor, \\ Amor, era mesmo pra valer, \\ Por isso a gente pena, sofre e chora, coração, \\ E morre todo dia sem saber.
}

A escrita desta dissertação foi um dos processos mais intensos da minha existência. Entre uma linha e outra, vocês poderão encontrar uma ou outra lágrima, algumas dezenas de sorrisos, uns copos de cerveja, uma meia dúzia de neurônios levada junto com os cabelos que eu tive que arrancar para produzir o trabalho. Mas há, acima de tudo, um pedaço de cada conversa, de cada amor, de cada carinho que eu tive a sorte de ter presente em minha vida. Assim, cambaleante entre afetos e dores, eu não me fiz só, por mais que não faltassem as tentações de isolamento que somente um procedimento acadêmico ainda tão rígido e castrador poderia provocar.

É por esse lampejo de vida que vocês me proporcionaram que devo agradecer.

E começo agradecendo à Emília, que, aparecendo como cometa nessa reta final, era a motivação que faltava, uma fonte de amor que faz toda entrega ser pequena.

Continuo agradecendo a quem, durante os últimos oito anos, foi presente todo o tempo como minha grande educadora. Foi deslumbrado pela experiência de liberdade e afeto de Miloca que eu pude abrir o coração à mais pura experiência de uma amizade, que não significa mais que compartilhar os bocados de vida pautados por sinceridade, diálogo, carinho e samba.

Tenho que agradecer, também com destaque, aos meus erre-dê-emes queridos. Crespo, Marcos, Marcel, Mari, Ana Gabi, Amaral, Dudu e Pepino, foi na alegria de vocês que encontrei força pra seguir em frente. Vocês jogaram a semente de onde brotou esta dissertação. Esperem-me para apertar e acender.

Pai, mãe, Maria Clara, Mariana: este agradecimento é também um pedido de desculpas pela ausência a que me forcei. Obrigado pela compreensão e pelo amor.

Agradeço a Sinara, Saiô, Gabi, Laura, Luna, Talitha, Bruna, Ana Paula e Marina, por me auxiliarem nesse alargamento de visão de mundo que vem por meio das lições quotidianas de luta e liberdade.

Ao Pedro Mahin e à Raissa, companheiros de viagens cambaleantes e carnavais malemolentes, meu muito obrigado.

À Laís, agradeço pela revisão cuidadosa de gestos, palavras e afetos, desde que me entendo por gente acadêmica. E também pelo zelo que dispensou ao texto desta dissertação, fazendo sugestões que foram imprescindíveis ao seu melhor desenvolvimento. 
Gostaria, ainda, de dar um muito obrigado especial à Veronica, pelo auxílio na revisão do texto e por tão ricas conversas diárias.

Agradeço ao John e ao Rafa, amigos queridos e primeiros a compartilharem comigo essa experiência desafiadora da docência, com uma pitada assim de biopolítica.

Ao Diego Nardi, companheiro de sempre, sou só gratidão pelas conversas de madrugada que nem mesmo 180 graus ao redor do globo foram capazes de impedir.

Muito obrigado, também, aos colegas de trabalho em Alino \& Roberto e Advogados, pela companhia diária na defesa das liberdades de quem pouco delas pode fruir, em razão da forma de sociedade legitimada pelos discursos hegemônicos sobre a economia, tratados neste trabalho.

Agradeço, ainda, ao Programa de Pós-Graduação em Direito da UnB, especialmente aos professores Alexandre Araújo Costa - meu paciente orientador e verdadeiro coautor deste trabalho -, Alexandre Bernardino Costa, George Galindo, José Geraldo de Sousa Junior e Juliano Zaiden, às professoras Claudia Roesler, Loussia Felix, Gabriela Delgado e Ela Wiecko e às servidoras Lia Alcântara, Kelly, Helena Meneses e Euzilene.

Por fim, agradeço aos colegas de pós-graduação, sempre firmes e dispostos às melhores discussões, todos e todas imprescindíveis ao desenvolvimento intelectual que experimentei ao longo dos últimos dois anos. Aos bukowinos Kelton, Henrique, Renatinha, Roberta, Douglas, Ludmila, Celina, Karol, Bruna, e ainda à Claudia, à Déia, ao João Guilherme, ao Guilherme del Negro, ao Nunes, ao Marcelo Torelly, à Lara, ao Roger, ao Gilberto, à Natalia Medina e ao Pedro Araújo, ao Gladstone, à Diana e a tantas outras fontes inesgotáveis de amizade e sabedoria.

À rua que não tem nome. Aos pequenos corações que não se deixaram perder pela história. Amo vocês. 


\section{SUMÁRIO}

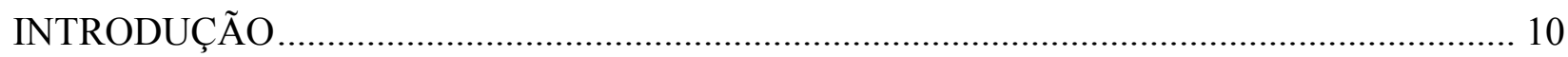

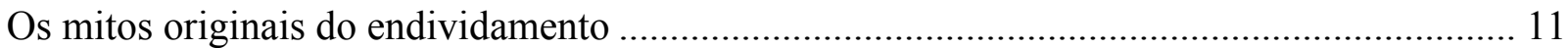

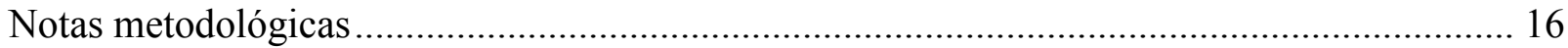

1 CONTEXTO DAS UNIDADES DE REGISTRO E DO MATERIAL ANALISADO UMA BREVE GENEALOGIA DA CRISE ARGENTINA............................................. 20

1.1 As transformações da ordem econômica capitalista................................................................ 21

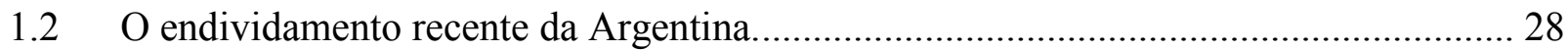

2 EXPLORAÇÃO DO MATERIAL - DECISÕES JUDICIAIS ANALISADAS. ....................... 35

2.1 Decisão da Corte de Cassação da Itália (Luca Borri v. Repubblica Argentina) .................... 35

2.2 Decisão do Tribunal Constitucional Federal Alemão (Argentinien-Anleihen) .................... 39

2.3 Decisão da Suprema Corte dos Estados Unidos da América................................................. 42

3 DO CONCEITO JURÍDICO DE SOBERANIA À PRÁTICA CONTEMPORÂNEA DA

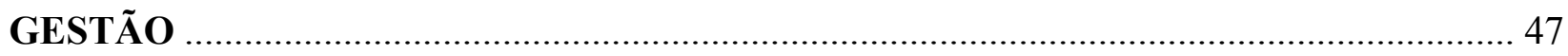

3.1 Poder absoluto e perpétuo... de não tocar em nenhum contrato ............................................ 47

3.2 A limitação da soberania no constitucionalismo democrático ................................................ 60

3.3 A nova governança - razão técnica e o vazio constitucional da economia política

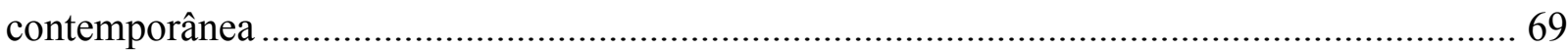

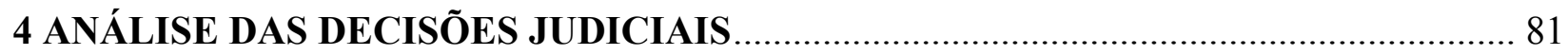

4.1 A questão da soberania e a divisão entre atos de império e atos de gestão .......................... 81

4.2 Que exceção como alternativa? Os limites do argumento do estado de emergência............ 95

4.3 Os direitos humanos entram na arena - as críticas à exigibilidade da dívida por um novo pleito de unidade em face da fragmentação dos regimes jurídicos autônomos. 103

4.3.1 A crítica de Sabine Schlemmer-Schulte ao abandono da retórica dos direitos humanos. 105

4.3.2 A construção da doutrina das dividas odiosas e sua aplicabilidade ao caso argentino. 108

4.4 O império contra-ataca - o resgate da política agonística para além das disputas epistêmicas. 


\title{
INTRODUÇÃO
}

\begin{abstract}
"O sistema de crédito público, é dizer, das dívidas nacionais, cujas origens remontam à Gênova e à Veneza medievais, tomou de conta da Europa como um todo durante o período manufatureiro. O sistema colonial, com seu comércio marítimo e suas guerras comerciais, serviu como incubadora para o sistema de crédito. Foi assim que fincou suas raízes na Holanda. A dívida pública, como alienação [Veräusserung] do Estado - seja ele despótico, constitucional ou republicano - marcou a era capitalista com seu selo. A única parte da assim chamada riqueza nacional que realmente se torna propriedade coletiva em uma nação moderna é a dívida pública".
\end{abstract}

— Karl Marx (MARX, 1976, p. 919, tradução livre).

O endividamento público dos países é um tema que tem escapado aos debates constitucionais. Naturalizado por séculos de uma prática política que recorrentemente adota a estratégia da constituição de dívidas públicas, esse fenômeno não costuma gerar o estranhamento necessário para que nos questionemos sobre a sua validade e sobre as dificuldades políticas e sociais que ele engendra. Em especial, tendemos a não discutir sobre as aporias jurídicas decorrentes de uma vinculação contratual do "soberano" com entes privados, possibilidade que frequentemente esbarra nas definições da teoria clássica da soberania e desencadeia uma série de conflitos cuja solução exige que nos aproximemos das zonas cinzentas de nossos modelos jurídicos e do caráter paradoxalmente limitado (COSTA, 2011, p. 203) das soberanias contemporâneas.

O enfrentamento da questão das dívidas soberanas exige a análise de um tipo de configuração social que tem implicações diretas sobre as redes de poder na atualidade e que envolve complexas relações entre direito e economia. A presente pesquisa explora justamente o denso tecido de relações jurídico-políticas que se entrelaçam nos discursos que fundamentam as decisões judiciais sobre esse tema.

O texto analisa três decisões judiciais que foram selecionadas por tratarem do mesmo objeto (a crise da dívida pública argentina no início dos anos 2000) a partir de óticas e linhas argumentativas bastante diversas acerca das relações entre poder soberano e endividamento público e das repercussões desse tema na teoria constitucional: 
1. Decisão da Corte Suprema de Cassação da Itália (Corte Suprema di Cassazione), na Ordinanza n. 6553/2005, datada de 25 de maio de 2005.

2. Decisão da Segunda Turma do Tribunal Federal Constitucional alemão (Bundesverfassungsgericht - BVG) no processo 2 BvM 1-5/03, 1, 2/06 (ArgentinienAnleihen), datada de 8 de maio de 2007.

3. Decisão da Suprema Corte dos Estados Unidos da América no processo Republic of Argentina v. NML Capital (n. 12-842), datada de 16 de junho 2014.

Essas decisões têm uma série de elementos comuns, que permitem estabelecer uma comparação entre as perspectivas que adotam. Trata-se de decisões tomadas por Cortes de competência constitucional, que abordam explicitamente as repercussões contratuais da atuação política de outro Estado e estabelecem um debate jurídico centrado na tensão entre duas categorias relevantes: gestão e soberania. Além disso, todos os julgamentos analisam o argumento utilizado pela República da Argentina de que havia um "estado de necessidade constitucional” a justificar a adoção de medidas emergenciais, o que permite uma comparação que evidencia as várias diferenças envolvidas nessas três abordagens.

O presente trabalho realiza uma análise qualitativa da documentação mencionada, com o propósito de verificar indutivamente os significados contextuais das categorias soberania e gestão. Com isso, pretende-se contribuir para o estabelecimento de balizas iniciais que permitam uma visualização preliminar das articulações entre os elementos conformadores da teoria constitucional hegemônica e os desenvolvimentos da economia política que desembocaram na primazia do endividamento público como um dos fundamentos da gestão da vida no mundo contemporâneo.

Nessa medida, a presente pesquisa faz parte do esforço mais geral de analisar o espectro das relações de poder forjadas na modernidade capitalista, contribuindo para o desenvolvimento de uma análise biopolítica da história recente das finanças globais.

\section{Os mitos originais do endividamento}

Existe um mito amplamente difundido em manuais de introdução à economia segundo o qual o sistema de crédito sucede, nas sociedades ditas "mais complexas", o sistema baseado em moedas que padronizam os mecanismos de troca, que por sua vez sucedeu os primitivos 
mecanismos de escambo. Uma das principais obras dos cursos brasileiros de iniciação à economia é o manual de Gregory Mankiw, que trata essa questão da seguinte forma.

O hábito social de usar dinheiro para transações é extraordinariamente útil em uma sociedade grande e complexa. Imagine, por um momento, que não haja qualquer item na economia que seja largamente aceito em troca de bens e serviços. As pessoas teriam de recorrer ao escambo - a troca de um bem ou serviço por outro - para obter as coisas de que precisam. Para conseguir sua refeição em um restaurante, por exemplo, você teria de oferecer ao restaurateur algo de valor imediato. Você poderia se oferecer para lavar alguns pratos, limpar o carro dele ou dar-lhe a receita secreto do bolo de carne da sua família. Uma economia que dependa do escambo terá dificuldades para alocar eficientemente seus recursos escassos. Numa economia desse tipo, diz-se que o comércio requer dupla coincidência de desejos - a improvável circunstância em que duas pessoas tenham, cada uma, os bens e os serviços que a outra deseja (MANKIW, 2009, p. 627628).

Essa fábula estabelece uma sociedade mítica primordial cujo desenvolvimento era impedido pela sua incapacidade de escapar das limitações intrínsecas do escambo, visto que ela somente poderia funcionar de forma eficiente se adotasse uma forma de organização social diversa. Trata-se do equivalente econômico das teses políticas evolucionistas de que as sociedades se iniciaram como famílias, que se uniram para formar clãs, que se uniram para formar cidades e assim, sucessivamente, até chegar ao ponto de conformar um Estado centralizado, no qual a política poderia efetivamente se realizar. No caso da economia, a narrativa tipicamente acentua que a complexificação das trocas sociais tornou imperativa a geração de um sistema monetário e, posteriormente, a formulação de um intrincado sistema de crédito, baseado na geração de capital fictício sob a forma de dívida, a qual alimenta-se de si própria por meio da idealização de instrumentos financeiros. Como é possível verificar, nenhum fundamento propriamente antropológico ou histórico, que se faça acompanhar da devida análise antropológica ou mesmo de uma simples observação de registros documentais de sociedades humanas em qualquer tempo, aparece para fundamentar a história da geração do dinheiro, em suas variadas formas. A sucessão apresentada é lógica, e não histórica, e aponta para um sentido necessário do progresso, o que indica que ela foi construída retrospectivamente, de modo a apontar que as estruturas atuais são decorrentes de uma evolução das estruturas antigas.

A força dessa narrativa evolutiva e progressiva influencia, inclusive, autores usualmente associado à esquerda contemporânea, como é o caso de Gilles Deleuze, que apontou no Postscriptum sobre sociedades do controle que o traço distintivo entre sociedades disciplinares e sociedades de controle poderia ser encontrado na forma como o dinheiro se configura nesses dois 
ambientes históricos: nas primeiras, o domínio do dinheiro se verificava a partir da existência de uma unidade-padrão, geograficamente homogênea e com valor convencionado de modo uniforme, enquanto nas segundas, o controle financeiro se estabelece por meio de "trocas flutuantes, modulações que fazem intervir como cifra uma percentagem de diferentes amostras de moeda" (DELEUZE, 1992, p. 222). Tal discurso guarda uma fundamental semelhança com aquele observado na obra de pensadores que compõem as bases do pensamento capitalista contemporâneo, tais como Adam Smith e todos aqueles que o sucederam nas cadeiras de Economia Política de índole liberal em diversos ambientes acadêmicos ao longo dos últimos dois séculos e meio.

Esse modo de contar a história do dinheiro como um avanço progressivo de relações concretas (escambo) a relações cada vez mais abstratas (o crédito) não se sustenta frente a uma análise de como se deu a construção dos instrumentos de crédito nas sociedades humanas. Como afirma David Graeber, “a versão difundida da história econômica tem muito pouco a ver com qualquer coisa que se observe quando se examina como a vida econômica realmente se desenrolou em comunidades e mercados reais, em quase todos os lugares" (GRAEBER, 2011, p. 26, tradução livre). Graeber indica que, ao longo do desenvolvimento do pensamento hegemônico da economia contemporânea, em que pesem os alertas de diversos antropólogos, mantém-se uma tradição de se pensar em termos absolutamente hipotéticos o desenvolvimento, ao longo do tempo, dos sistemas de troca. Não obstante, esse modo de contar a história desempenhou um papel fundamental na formulação de uma ciência econômica, e também na criação "da ideia de que existe algo chamado 'a economia', que opera por meio de suas próprias regras, divorciada das vidas moral e política, e que pode ser apropriada pelos economistas como um campo de estudo" (GRAEBER, 2011, p. 32, tradução livre), gerador de verdade.

A ideia de verdade é imprescindível a este trabalho. De um lado, porque ele busca - sem nenhuma garantia de sucesso - afastar-se da pretensão de, com claras intenções políticas, forjar valor de verdade às normatividades que seu autor defenda. Não se trata, aqui, “de libertar a verdade de todo sistema de poder - o que seria quimérico na medida em que a própria verdade é poder mas de desvincular o poder da verdade das formas de hegemonia (sociais, econômicas, culturais) no interior das quais ela funciona no momento" (FOUCAULT, 1979, p. 14). De outro, porque tem por meta, mediante uma "intensificação do pensamento" (FOUCAULT in DELEUZE; GUATTARI, 1977, p. XIII), fornecer uma abertura à ação política, desvelando a verdade não como um dado, mas como "um conjunto de procedimentos regulados para a produção, a lei, a repartição, 
a circulação e o funcionamento dos enunciados", localizado no interior de "sistemas de poder, que a produzem e a apoiam" e vinculado a "efeitos de poder que ela induz e que a reproduzem" (FOUCAULT, 1979, p. 14).

É à sua verdade que o sistema econômico se reporta ao gerar a própria fábula de sua história, que fatalmente desemboca na legitimação de instrumentos financeiros de endividamento que são parte integrante da economia contemporânea. Não é preciso, afinal, mais do que assistir ao telejornal noturno ou ler as notícias diárias nos cadernos de economia dos grandes jornais para identificar a importância que adquiriram termos como derivativos, superávit primário, ou a relação dívida-PIB dos países ocidentais. Esses elementos constituem parte relevante do que se convencionou chamar de "política econômica" dos Estados contemporâneos, e influem diretamente sobre as poupanças das famílias, o nível de crédito ofertado e mesmo sobre a fruição de direitos previstos nas diversas cartas constitucionais.

O modo como se conta a história da economia capitalista desempenha um papel crucial nesse processo. É essa narrativa que permite a emergência da economia como um discurso autorizado e bastante homogêneo, ocupante de lugar privilegiado nas sociedades ocidentais contemporâneas e que, ao mesmo tempo, serve para diminuir ou reduzir o lugar nelas ocupados pelo campo propriamente político. Mais do que uma decisão política baseada em interesses estratégicos, o endividamento é apresentado como uma consequência necessária da evolução social rumo a organizações mais complexas, como um elemento inescapável do progresso técnico das sociedades humanas, inserindo-se, desse modo, no interior de uma moldura que, sucedendo as visões deontológicas que caracterizaram a fundação e a legitimação do constitucionalismo, desalojou-o e o reprimiu, ao mesmo tempo em que dele se valeu para fundamentar seu modo de atuação (KOSKENNIEMI, 2007). Assim é que, especialmente a partir da segunda metade do século XX, fortaleceu-se certo discurso que enfraquece mesmo as categorias que pareciam indispensáveis à conformação de um discurso propriamente moderno sobre o poder, como a ideia de legitimidade política. Tal preocupação não escapou dos olhos cuidadosos dos sociológicos vinculados à tradição da teoria crítica e, ainda na década de 1970, chamou-se a atenção para o tema, como demonstra o seguinte trecho, produzido no âmbito da discussão sobre a emergência de governos tecnocráticos nos países ocidentais:

A tarefa do político, agora, só pode ser a de assegurar o funcionamento ótimo desta organização técnico-estatal e de produzir um rendimento máximo, sendo que esse rendimento não é medido segundo quaisquer objetivos, mas sim segundo as forças 
disponíveis. Desta forma, a legitimação política se reduz à disponibilidade técnica. (...) Deste modo, a tecnocracia surge sob uma nova ótica: não são os técnicos ou os especialistas que dominam, mas sim a técnica com usa lógica própria e impessoal (ROPOHL, 1975, p. 53-54)

Daí se depreende que a emergência de técnicas específicas de governo como verdades irrefutáveis ou ao menos como estratagemas políticos de primeira ordem, cuja violação implica a tragédia de toda uma comunidade, engendrou uma visão de mundo eminentemente impessoal, que retira da figura do governante, ou mesmo do técnico responsável pela emissão dos significados de enunciados políticos, a visibilidade das vontades de poder levadas a cabo por esses enunciados. Não é difícil perceber que a discussão acaba por se encaminhar para uma via linguística em que o enunciado gira em torno de si, sem comportar uma análise mais aprofundada sobre os enfrentamentos que acarretaram a emergência da visão política a que se pretende atribuir um valor de verdade. A perspectiva que aqui se pretende desenvolver, por seu turno, parte de um ponto distinto, diagnosticando que "aquilo que se deve ter como referência não é o grande modelo da língua e dos signos, mas sim da guerra e da batalha", por se compreender, a partir de fragmentos históricos aqui recortados, que "a historicidade que nos domina e nos determina é belicosa e não linguística", é "relação de poder, não relação de sentido" (FOUCAULT, 1979, p. 5).

A grande vantagem de uma teoria que se limita a discutir significações e que conta a história baseada em suposições e hipóteses não comprovadas de funcionamento das sociedades ditas primitivas é que ela se isenta da responsabilidade de falar sobre os sujeitos que se constituem no interior de relações específicas de dominação. Tornou-se lugar comum, dessa maneira, contar o desenvolvimento temporal do capitalismo ou do liberalismo econômico meramente a partir do discurso sobre a liberdade dos indivíduos, olvidando-se ou ocultando-se, de um lado, a antiguidade de práticas vistas como absolutamente particulares de nosso tempo e, de outro, uma história de violências, violações e dominações que não raramente ganharam contornos jurídicos.

Não por acaso, a emergência do discurso econômico pautado na liberdade dos indivíduos acaba por vir à tona juntamente com o descrédito das instituições políticas para regrar as matérias de disciplina econômica e com um amplo amparo na legitimidade jurídica das liberdades individuais. A seguir, delineia-se um caráter propriamente mítico dessas três instituições, algo imprescindível para a compreensão do contexto no qual se insere a discussão sobre o endividamento público argentino do início dos anos 2000. 


\section{Notas metodológicas}

Este trabalho consistiu em uma análise documental qualitativa, de caráter exploratório, realizada por meio da análise do conteúdo de três decisões de cortes constitucionais que dizem respeito às decorrências da reestruturação da dívida pública da República Argentina levada a cabo pelo governo daquele país no início do século XXI. Lançou-se mão da técnica da análise de conteúdo, consistente em uma gama de recursos metodológicos voltados à análise linguística de comunicações socialmente enunciadas, a partir da delimitação de unidades de codificação, de registro e de contexto que possibilitem uma apreciação dos usos de categorias mediante inferências organizadas em torno de determinadas condições de produção e recepção dos sentidos textuais (BARDIN, 2002). Como afirma Laurence Bardin:

O analista é como um arqueólogo. Trabalha com vestígios: os "documentos" que pode descobrir ou suscitar. Mas os vestígios são a manifestação de estágios, de dados e de fenômenos. Há qualquer coisa para descobrir por e graças a eles. Tal como a etnografia necessita da etnologia, para interpretar as suas descrições minuciosas, o analista tira partido do tratamento das mensagens que manipula, para inferir (deduzir de maneira lógica) conhecimentos sobre o emissor da mensagem ou sobre o seu meio. Tal como um detetive, o analista trabalha com indices cuidadosamente postos em evidência por procedimentos mais ou menos complexos. Se a descrição (a enumeração das características do texto, resumida após tratamento) é a primeira etapa necessária e se a interpretação (a significação concedida a estas características) é a última fase, a inferência é o procedimento intermediário, que vem permitir a passagem, explícita e controlada, de uma à outra (BARDIN, 2009, p. 39).

O caráter exploratório da pesquisa se revela no fato de que seu objetivo principal é fornecer subsídios para uma arqueologia dos saberes jurídicos sobre o endividamento público, descrevendo alguns elementos desse campo de modo a abrir espaço para que pesquisas futuras adotem marcos mais específicos e possam explorar hipóteses de caráter mais abstrato e generalizante. A presente abordagem não possibilita a formulação de enunciados gerais sobre os padrões de endividamento público nem de suas repercussões jurídicas, mas a densidade das decisões analisadas permite a formulação de estratégias, categorias e hipóteses de trabalho capazes de contribuir para as futuras pesquisas no campo.

Para a consecução desse objetivo, a análise de conteúdo foi organizada em três etapas, segundo a classificação de Laurence Bardin: (1) pré-análise, em que se define o material a ser analisado; (2) exploração do material; e (3) tratamento dos resultados, inferência e interpretação (BARDIN, 2002).

A pré-análise "é a fase de organização propriamente dita” (BARDIN, 2009, p. 95), na qual se busca formular uma primeira sistematização de ideias, por meio de três objetivos iniciais: "a 
escolha dos documentos a serem submetidos à análise, a formulação das hipóteses e dos objetivos e a elaboração e indicadores que fundamentem a interpretação final” (BARDIN, 2009, p. 95). Para a escolha do material submetido a apreciação, foram respeitados três critérios: exaustividade (não seletividade), representatividade, homogeneidade e pertinência.

Para que a pesquisa fosse exaustiva, o critério de seleção do corpus documental foi: decisões de cortes constitucionais atinentes à matéria do endividamento público da Argentina em razão do default anunciado por aquele país no ano de 2002. De acordo com a regra da exaustividade, "uma vez definido o campo do corpus (...), é preciso terem-se em conta todos os elementos desse corpus" (BARDIN, 2009, p. 97). Assim, foram recenseadas as decisões de cortes constitucionais a respeito da exigibilidade, por credores privados, dos títulos públicos argentinos, excluindo-se apenas aquelas que não abordavam categorias especificamente constitucionais, por aplicação da regra da representatividade. Segundo tal regra, "nem todo o material de análise é susceptível de dar lugar a uma amostragem, e, nesse caso, mais vale abstermo-nos e reduzir o próprio universo (e portanto o alcance da análise)" (BARDIN, 2009, p. 97-98). Por fim, foram selecionadas decisões homogêneas e pertinentes, escolhendo-se documentos que não apresentassem muitas singularidades que excedessem aos parâmetros de escolha das decisões (BARDIN, 2002, p. 98). Aplicados esses critérios, foram selecionadas as três decisões já mencionadas, pois em todas elas era possível verificar a presença de elementos que levavam, de algum modo, à discussão sobre o papel desempenhado pelo Estado na negociação de títulos da dívida pública. É dizer: debatia-se se a Argentina ocupa, nessa condição, a posição de sujeito soberano, verticalmente localizado em relação aos particulares, ou se ocupa a posição de agente contratante, horizontalmente vinculado aos seus credores.

Trata-se de uma discussão relevante para os debates contemporâneos da teoria do direito, com reflexos que transcendem a discussão sobre o endividamento público. A matéria importa especialmente diante do florescimento de certo pluralismo jurídico que desafia diversos elementos do direito moderno. Desafia, em primeiro lugar, o conceito consagrado de soberania, tida como poder ilimitado, absoluto e perpétuo de que é dotada certa autoridade (BODIN, 1997). Em segundo lugar, mesmo a tese constitucional-democrática de uma soberania limitada, determinada pela imposição de freios mútuos entre política e direito ${ }^{1}$, encontra aqui um teste extremo, pois se põe

\footnotetext{
${ }^{1} \mathrm{Na}$ tradição do constitucionalismo democrático liberal, "o direito constitui o poder político e vice-versa", pois "a formação política da vontade culmina em decisões sobre políticas e leis, que precisam ser formuladas na linguagem do direito" (HABERMAS, 2003, p. 210-211). Traduzindo-se em termos institucionais, "a competência legislativa, que
} 
em xeque a prerrogativa de governos democraticamente eleitos ou mesmo das populações dos Estados ditos soberanos de escolher, segundo regras majoritárias, o caminho a ser seguido quando o tema é o pagamento das parcelas da dívida pública de um país. Em tal contexto, verifica-se que o nosso mundo

já não é um mundo de Estados que se apoiam no poder coercitivo e no capital (com peso cada vez maior no capital), mas um mundo no qual esses Estados têm de dividir seu poder com "o capital multinacional, representado pelo comércio de drogas, armas, eletrônicos, publicações, petróleo ou ações, o qual tem assumido considerável poder e mobilidade de forma parcialmente independente dos Estados cujos residentes criaram e acumularam (esse mesmo) capital" (Tilly, 1995, p. 26). Num mundo assim, a noção tradicional (e, a propósito, conceitualmente contraditória [Kelsen, (1920) 1981]) de soberania estatal não mais se reveste de qualquer importância, em vista de qualquer sentido do termo soberania (como na definição de Hobbes da soberania como o "Deus terreno" monoteísta). (BRUNKHORST, 2011, p. 8)

Diante disso, assiste-se com alguma perplexidade à emergência de uma ordem em que as normatividades múltiplas derivam de um contexto altamente especializado e fragmentado de produção do direito. Nos termos de Gunther Teubner, trata-se de um "novo direito mundial [que] não se nutre de estoques de tradições, e sim da auto-reprodução contínua de redes globais especializadas, muitas vezes formalmente organizadas e definidas de modo relativamente estreito, de natureza cultural, científica ou técnica" (TEUBNER, 2003, p. 14). Nesse horizonte, ganha destaque um direito econômico internacional pautado por contratos que "não só estão separados das suas raízes no direito nacional, como também perdem toda sustentação em qualquer ordenamento jurídico" (TEUBNER, 2003, p. 21).

Diante dessa percepção corrente nos círculos teóricos contemporâneos, pôde-se formular a hipótese inicial de que as decisões contribuiriam para expor determinada sucessão de cosmovisões: as cortes constitucionais, apropriando-se de certo jus gestionis desenvolvido à parte de suas categorias convencionais, teriam abandonado a prevalência da teoria da soberania, centrada no papel do Estado-nação soberano, e cedido espaço à emergência de normatividades contratuais, em que o Estado não é mais que uma parte da relação negocial com seus credores, à qual não é dado o direito de descumprir obrigações unilateralmente.

fundamentalmente é atribuída aos cidadãos em sua totalidade, é assumida por corporações parlamentares, que fundamentam leis de acordo com um processo democrático" (HABERMAS, 2003, p. 215). Assim sendo, se é violado o esquema constitucional de separação de poderes, tem-se uma vulneração da relação que confere legitimidade ao discurso jurídico, pois resta quebrado o ciclo de legalidade que faz com que poderes distintos se controlem mantendo um âmbito próprio de atuação. De acordo com essa tese, caso se aceite a institucionalização de razões de governo (estabilidade institucional, decisão técnica sobre política econômica, dentre outras) como pretextos para a violação das razões político-institucionais constitucionalmente estatuídas, o que se está a fazer é legitimar, no interior da ordem constitucional, a exceção a esta ordem como a regra nela vigente. 
Em face dessa hipótese, elegeram-se como categorias-chave para fins de indexação e comparação entre as decisões os termos soberania, estado de necessidade e imunidade de jurisdição, por constituírem os temas indiciários que, como se demonstrará, dão o tom das decisões proferidas na Itália, na Alemanha e nos Estados Unidos da América. São tais categorias que passam a compor as unidades de registro em torno das quais se desenvolverá o presente trabalho ${ }^{2}$.

\footnotetext{
${ }^{2}$ A unidade de registro "é a unidade de significação a codificar e corresponde ao segmento de conteúdo a considerar como unidade de base, visando a categorização e contagem frequencial" (BARDIN, 2002, p. 104). Pode consistir, em análise mais quantitativas, em palavras ou, em análises temáticas qualitativas, em temas, personagens ou acontecimentos.
} 


\section{CONTEXTO DAS UNIDADES DE REGISTRO E DO MATERIAL ANALISADO - UMA BREVE GENEALOGIA DA CRISE ARGENTINA.}

Conforme afirma Laurence Bardin, em diversas pesquisas é "necessário fazer (conscientemente) referência ao contexto próximo ou longínquo da unidade a registrar", especialmente quando "a intensidade e a extensão de uma unidade podem surgir de modo mais ou menos acentuado, consoante as dimensões da unidade de contexto escolhida" (BARDIN, 2002, p. 107). Este é o caso do presente estudo, cuja devida compreensão exige um conhecimento prévio do contexto social, político e econômico em que se insere a discussão sobre o endividamento público argentino. Como esse tipo de conhecimento não integra o horizonte típico de compreensão dos juristas, torna-se necessário começar o trabalho com uma exposição panorâmica acerca da crise da dívida argentina e também de certos elementos teóricos ligados ao endividamento público.

A Argentina, assim como a maior parte dos países hoje subdesenvolvidos, possui um histórico de endividamento que remonta à sua própria constituição como Estado independente. $\mathrm{O}$ país realizou sua primeira operação de crédito em 1824, oito anos após o fim da guerra de independência, celebrando contrato de empréstimo no valor de um milhão de libras esterlinas com o banco Baring Brothers, de Londres, das quais apenas 552.700 - pouco mais da metade - foram efetivamente aproveitadas pelo Estado, enquanto que todo o restante foi destinado ao pagamento de juros antecipados e amortização adiantada da própria dívida ${ }^{3}$ (GALASSO, 2003). No entanto, foi somente após o boom financeiro dos anos 1970 que a dívida pública da Argentina ganhou contornos mais expressivos e um maior peso no montante total do produto daquele país (DAMILL; FRENKEL; RAPETTI, 2005).

Tratou-se de um processo inserido em um contexto global mais amplo, ligado às condições que se consolidaram no pós-guerra. Na esfera propriamente financeira, o ambiente internacional (e especialmente a crescente influência dos EUA) estimulava a instituição do que passou a se denominar de neoliberalismo financeiro, que implicou uma abertura comercial dos países e o estímulo a um desenvolvimento econômico acelerado, o que exigia a formulação de estratégias inovadoras de fomento econômico e financiamento.

Instaurou-se um arcabouço internacional de comércio e desenvolvimento econômico no interior e entre esses Estados independentes por meio do Acordo de Bretton Woods, a fim de estabilizar

\footnotetext{
${ }^{3}$ Para fins de parâmetros comparativos, o Brasil pediu empréstimo de três milhões de libras, nessa mesma época (o famoso "empréstimo português") aos bancos inglese. A população brasileira, nesse período, era cerca de sete vezes maior que a argentina.
} 
o sistema financeiro mundial, o que se fez acompanhar por toda uma bateria de instituições, como o Banco Mundial, o FMI, o Banco Internacional de Compensações na Basileia, e da formação de organizações como o GATT (Acordo Geral De Tarifas e Comércio) e a OCDE (Organização para Cooperação e Desenvolvimento Econômico), projetadas para coordenar o crescimento econômico entre as potências capitalistas avançadas e levar o desenvolvimento econômico de estilo capitalista ao resto do mundo não comunista. (HARVEY, 2013, p. 52)

Esse processo não se deu sem que antes se operasse, no âmbito dos micropoderes, uma meticulosa articulação de elementos que propiciaram as condições de aparecimento de uma ordem neoliberal, caracterizada pela subversão aos fundamentos de estabilização econômica que marcaram a primeira metade do século XX: (1) o New Deal e as políticas keynesianas de desenvolvimento; (2) os mecanismos estatais de segurança social desenvolvidos durante a Segunda Guerra; e (3) os programas de planejamento econômico estatal que ganharam corpo até a presidência de Lyndon Johnson nos Estados Unidos e em todos os países europeus no pós-guerra (FOUCAULT, 2008a).

\subsection{As transformações da ordem econômica capitalista.}

A teoria econômica desenvolvida até então havia deixado de analisar em sua dimensão mais concreta: o fator trabalho. O neoliberalismo americano retorna à ideia do homo aeconomicus para igualá-lo ao trabalhador que recebe sua renda e reflete sobre como empregá-la. Assim, tornase "um empresário de si mesmo, sendo ele próprio seu capital, sendo para si mesmo seu produtor, sendo para si mesmo a fonte da sua renda" (FOUCAULT, 2008, p. 311). Há, aqui, um claro processo de formação de subjetividades: o discurso de verdade do neoliberalismo forja o homem e a mulher como produtores, sendo que essa produção não é valorizada como poeisis (no sentido de ser uma forma de criar produtos significantes), mas apenas como uma produção de renda que serve como meio para possibilitar o consumo de bens. Formula-se um discurso de produção de si, mas a identidade assim gerada não decorre do que se produz, mas do que se acumula e se consome. Não se trata mais do estímulo de que os indivíduos se vejam como partes de uma unidade produtiva estável, de uma empresa cuja operação envolve a atividade coordenada de várias pessoas. Em vez disso, política social do imediato pós-guerra estimula que a atividade de cada pessoa seja entendida como um empreendimento pessoal, convertendo as pessoas em uma forma de empresa-indivíduo, cujo sucesso deve ser medido no nível individual, e não no nível das organizações a que ela pertence. 
Quer dizer, de um lado, generalizar de fato a forma "empresa" no interior do corpo ou do tecido social; quer dizer, retomar esse tecido social e fazer que ele possa se repartir, se dividir, se desdobrar, não segundo o grão dos indivíduos, mas segundo o grão da empresa. A vida do indivíduo não tem de se inscrever como vida individual num âmbito de grande empresa, que seria a firma, ou, no limite, o Estado, mas (tem de) poder se inscrever no âmbito de uma multiplicidade de empresas diversas, encaixadas e entrelaçadas, de empresas que estão, para o indivíduo, de certo modo ao alcance da mão, bastante limitadas em seu tamanho para que a ação do indivíduo, suas decisões, suas opções possam ter efeitos significativos e perceptíveis, bastante numerosas também para (que ele) não fique dependente de uma só; e, enfim, a própria vida do indivíduo como, por exemplo, sua relação com a sua propriedade privada, com o seu casamento, com os seus seguros, com a sua aposentadoria - tem de fazer dele como que uma espécie de empresa permanente e de empresa múltipla. (FOUCAULT, 2008, p. 331-332)

Essa reinterpretação do indivíduo como empresa, faz parte de um movimento mais geral de interpretação da sociedade a partir de categorias econômicas, realizada especialmente pelas escolas neoliberais. A forma-mercado se difunde por todo o meio social, passando a funcionar como "princípio de decifração das relações sociais e dos comportamentos individuais" (FOUCAULT, 2008, p. 334), de modo que tal forma age como elemento impulsionador não apenas dos negócios, mas também da administração pública, da economia informal, do mercado de trabalho, da inovação social e até mesmo dos setores culturais e acadêmicos (HARVEY, 2012). Tudo que possa ser transformável em bem de consumo torna-se uma forma de capital associada aos produtores individuais desse capital. Além disso, todos esses elementos são integrados à nova realidade do mundo financeiro, em um contexto de acumulação flexível no qual o papel-moeda perde sua exclusividade e tudo pode se transformar em ativos e em créditos.

Na dimensão do trabalho, as corporações se tornam mais horizontalizadas, mas a redução de níveis hierárquicos não desencadeia processos democráticos de tomada de decisão, e sim uma radicalização das pressões por eficiência (just-in-time), em um sistema no qual o trabalhadorempreendedor é levado a flexibilizar suas habilidades, contorcendo-se entre múltiplas funções. No modelo anterior, a empresa assumia os riscos do negócio e a produtividade era conquistada por sistemas centralizados de administração de pessoas, capazes de garantir a ação coordenada dos indivíduos. No modelo atual, trabalhadores organizados em grupos são levados a discutir seu próprio desempenho e a participar de processos decisórios empresariais que, focados no aumento da produtividade, vinculam a si próprios (ANTUNES, 2003). Em vez de um sistema no qual a eficiência máxima é conquistada pela existência de organizações centralizadas que coordenam as atividades das pessoas, espera-se que cada pessoa seja responsável por extrair de si mesma o máximo de eficiência produtiva. 
Não se trata mais de um sistema com gerentes capazes de impor uma ação disciplinada aos seus funcionários, mas de um sistema que somente pode funcionar com pessoas autodisciplinadas de modo a que elas próprias atuem maximizando sua eficiência individual. Esse ambiente que privilegia indivíduos capazes de se adaptar continuamente a um contexto fluido e que contam para isso com uma alta capacidade de aprendizado e de flexibilidade comportamental, deixando um espaço mais restrito para pessoas que buscam alterar o próprio ambiente, a partir de uma ação política de caráter coletivo. A ideia liberal de que o acoplamento de comportamentos individuais maximizadores de eficiência conduzirá ao melhor arranjo possível do conjunto está em tensão com a ideia de que as pessoas devem coordenar suas ações em função de um bem que as transcende, e que somente pode ser alcançado pela ação política. Não há quem escape, na contemporaneidade ocidental, da forma particular de mercantilização da vida pela qual os indivíduos se percebem como integrantes de um mercado governado pelas leis impessoais da oferta e da demanda, mais do que como integrantes de uma sociedade dotada de autonomia política.

Enquanto nas perspectivas socialdemocratas cabe ao Estado realizar uma mediação entre o indivíduo e o mercado (mantendo alguns espaços no campo político da decisão coletiva), o mindset neoliberal promove uma total imersão dos indivíduos em mercados cuja operação é blindada contra intervenções política. No contexto de um mercado que opera livremente, a única saída que se apresenta como viável é a de que cada indivíduo desenvolva sua plasticidade individual para se adaptar aos contextos fluidos e incontroláveis que emergem das relações sociais, em vez de se fiar na capacidade coletiva de modelar politicamente essas próprias relações, capacidade essa que passa a ser apresentada como uma forma de utopia. Nesse ambiente, o direito tende a estar engajado na preservação do ajuste político pelo qual os riscos são assumidos por todos, embora os ganhos sejam bastante concentrados em alguns grupos. Uma das manifestações mais evidentes dessa economia política do corpo, transfigurada num espectro jurídico, encontra-se no direito penal, centrado na percepção do crime enquanto "toda ação que faz um indivíduo correr o risco de ser condenado a uma pena", deixando de existir qualquer distinção entre um infrator de trânsito e um assassino serial (FOUCAULT, 2008, p. 344-346). O criminoso é também homo aeconomicus, sobre o qual operam-se cálculos de gestão com vistas a se obter o máximo de eficiência no processo punitivo, de acordo com uma lógica absolutamente vinculada à economia capitalista moderna - $\mathrm{o}$ sistema penal torna-se um ajuste da oferta e demanda, voltado ao controle de externalidades de determinados atos. Como relata Loïc Wacquant, 
Esse projeto envolve a reorganização e a realocação do Estado para reforçar mecanismos semelhantes ao mercado e disciplinar o novo proletariado pós-industrial, restringindo, ao mesmo tempo, os distúrbios internos gerados pela fragmentação da mão de obra, a redução dos esquemas de proteção social e a reorganização correlata da hierarquia étnica estabelecida (etnoracial nos Estados Unidos, etnonacional na Europa Ocidental e uma mistura das duas na América Latina). (WACQUANT, 2012)

No âmbito da regulação econômica, não é distinto o movimento que passa a ocorrer. Associado aos discursos já então hegemônicos em torno do rule of law e da democracia constitucional, o neoliberalismo passou a prover sua própria normatividade, a qual se deu em torno dos conceitos de privatização, desregulamentação, austeridade, terceirização e corte de impostos (MATTEI; NADER, 2008). Nesse contexto, seu foco de atuação deixa de ser os Poderes Legislativo e Executivo, passando a se enfatizar o papel do Judiciário como um intermediador dos interesses particulares em conflito no interior de uma sociedade-mercado. Se já era evidente o rechaço ao papel do Executivo formulador de políticas sociais, resgatado dos tempos do liberalismo clássico, a novidade é a aversão ao próprio Poder Legislativo, visto por ricardianos, smithianos e mesmo pelos ordoliberais alemães como garantidor da segurança jurídica e da justa concorrência. Nos tempos do neoliberalismo, a justiça pública das leis dá lugar a atribuições cada vez mais acentuadas dos juízes, que deixam de ser a boca que enuncia as palavras das normas gerais e abstratas e passam a se comportar como árbitros garantidores da autonomia dos mercados para estabelecer relações voltadas a maximizar a eficiência econômica. Em síntese, tem-se o que enunciam Ugo Mattei e Laura Nader:

A teoria política e econômica do neoliberalismo pode ser considerada o produto de uma ideologia econômica conservadora tornada acessível a não-economistas pelos epígonos da escola austríaca, como Friedrich von Hayek. A crítica à ordem anterior levou à formulação de diversos dogmas. $\mathrm{O}$ estado social, longe de ser considerado pelos neoliberais como uma das mais avançadas fronteiras que poderia ser alcançada pela civilização no interior do capitalismo, é tratado como uma organização burocrática desprezível, que deve ser abandonada tão logo seja possível. A regulação estatal - um sistema legislativo que organiza a estrutura do estado social, coordena a relação entre o indivíduo e as organizações públicas e cuida da sociedade por meio da regulação da distribuição da riqueza - é tachada de corrupta, como se fosse capturada por interesses especiais. Ela é tratada como um fator corruptor de uma ordem legal natural, espontânea, baseada em case-laws, que protege os direitos de propriedade e se baseia nas cortes como os foros centrais de solução de problemas envolvendo particulares no interior de um mercado livre. Explorando a relação ambígua entre o socialismo e as teorias sociais, econômicas e políticas que embasam o estado social, o neoliberalismo enfatiza o valor da liberdade individual e retrata o Estado, uma vez mais, como um Leviatã por natureza, inimigo da propriedade privada e da autodeterminação. Como nos tempos de Sir Edward Coke, um governo progressista e proativo que tente redistribuir alguma riqueza pública entre as classes sociais em prol dos interesses dos menos favorecidos é apresentado como uma violação do rule of law. (MATTEI; NADER, 2008, tradução livre)

Todo esse esquema epistemológico, é preciso dizer, impõe-se não propriamente mediante um hegemon instituído verticalmente, mas como forças difusas em sociedade, a tornar todos e cada 
um de nós cúmplices das formas reais e simbólicas das violências que, mais ou menos silenciosas, impõem-se com facilidade mesmo por meio de movimentos contestatórios. Esses não deixam de se pautar pela linguagem forte da autonomia e da liberdade individuais, elementos indissociáveis da gramática neoliberal instituída a partir da segunda metade do século $\mathrm{XX}^{4}$.

Foi esse complexo intricado de novas práticas sociais que Michel Foucault denominou de uma governamentalidade neoliberal, que se fortaleceu a partir da década de 1970 e permitiu a instituição de uma distinta percepção a respeito do papel do Estado e dos sujeitos nos cálculos de governo. O liberalismo clássico rompeu com a raison d'État que, entre os séculos XVI e XIX na Europa Ocidental, buscou legitimar o crescimento do Estado sobre as regulações das relações sociais. Originado na máxima segundo a qual sempre há governo demais, o liberalismo inspirou as desconfianças contra o aparato estatal centralizado, impondo uma cisão entre Estado e sociedade civil que representou uma tecnologia específica do poder com grande ressonância a partir do século XIX, forjada a partir da concepção de um homo aeconomicus como sujeito de interesses ${ }^{5}$ que é, ao mesmo tempo, objeto de um laissez-faire. A partir da teorização desse "átomo de liberdade", formula-se uma arte de governar que deixa de derivar da autoridade suprema ou da vontade

\footnotetext{
${ }^{4}$ Uma crítica ao uso contestatório da autonomia é fornecida, mais recentemente, por teóricas como Judith Butler. Aqui, afiliamo-nos a uma visão semelhante que, longe de pretender condenar o recurso à autonomia, firma-se na premissa de que, para além dela, faz-se necessário articular um uso público dos corpos afetados por normatividades que lhes são externas, sejam elas de centralidade estatal ou mercadológica. Butler desenvolve a crítica no contexto específico dos direitos sexuais e reprodutivos, mas ela poderia ser estendida com alguma facilidade a outros movimentos contestatórios que, ao longo do tempo, acabaram por focar excessivamente os direitos e as liberdades individuais. Atenta ao alerta foucaultiano de que o indivíduo - e também os direitos a ele vinculados - é sempre um produto do poder (FOUCAULT in DELEUZE; GUATTARI, 1977), Butler escreve: "Ao mesmo tempo, é essencial a muitos movimentos políticos a reivindicação da integridade do corpo e da autodeterminação. É importante reivindicar que nossos corpos são nossos no sentido de que são de nós próprias e de que nós somos legitimadas a requerer direitos de autonomia sobre nossos corpos. Essa afirmação é uma verdade para os pleitos de direitos de gays e lésbicas à liberdade sexual, assim como o é para as reivindicações de transexuais e transgêneros por autodeterminação, e também aos pleitos intersexuais pelo direito de serem liberados de intervenções psiquiátricas e médicas coercitivas. Essa é uma verdade para todas as reivindicações em prol do fim dos ataques racistas físicos e verbais, assim como para as reivindicações feministas de direitos reprodutivos, ou para aqueles cujos corpos trabalham de modo política ou economicamente aprisionado, sob condições de colonização e ocupação. É difícil, senão impossível, fazer essas reivindicações sem recorrer à autonomia. Não estou sugerindo que nos devêssemos parar de realizar esses pleitos. (...) Mas existe outra aspiração normativa que nós precisamos também buscar articular e defender? (...) O corpo implica mortalidade, vulnerabilidade, ação: a pele e a carne nos expõem à contemplação de outros, mas também ao toque e à violência; nossos corpos nos colocam sob o risco de nos tornarmos correias de transmissão disso tudo. Embora nós lutemos por direitos sobre os nossos próprios corpos, os mesmos corpos pelos quais nós lutamos não são nem mesmo somente nossos. O corpo tem sua dimensão pública invariável. Constituído como um fenômeno social na esfera pública, meu corpo é e não é meu ao mesmo tempo" (BUTLER, 2006, p. 25-26, tradução livre).

${ }^{5}$ Nas palavras de Adam Ferguson, no seu Essay on the history of civil society: "Os homens são tentados ao trabalho e à prática das artes lucrativas, por razões de interesse. Assegure ao trabalhador os frutos do seu trabalho, dê-lhe o panorama da independência e da liberdade, e o público terá encontrado um ministro leal da aquisição de riquezas, e um servo fiel da acumulação do que se ganhou" (FERGUSON, 1787, p. 239, tradução livre).
} 
discricionária do soberano. Trata-se de uma verdadeira sucessão do governo de homens pelo governo de leis, em que "o mundo da economia deve ser obscuro e é necessariamente obscuro para o soberano" (FOUCAULT, 2008, p. 381). Se, de um lado, o poder político deve se abster de uma incursão econômica em uma vertente liberal clássica, de outro, nessa mesma ótica, tem-se uma limitação ao uso da economia - ela não implica mais que a prerrogativa de cada indivíduo de aplicar, onde desejar e da forma que lhe aprouver, os recursos de que dispõe. Ao Estado, não é dado intervir; ao mercador, não é dado projetar-se para além da economia em si, assim entendida como a arte do acúmulo de capital. Outra não é a leitura que se pode extrair do seguinte trecho da obra clássica de Adam Ferguson:

No comércio, está-se a tratar de fazer o indivíduo enriquecer; quanto mais ele ganha, mais ele
contribui para aumentar a riqueza da nação. Se se requer uma proteção, ela deve ser garantida; se
crimes e fraudes são cometidos, eles devem ser reprimidos; e o governo não pode pretender nada
mais que isso. Quando o político refinado emprega uma mão ativa, ele apenas multiplica as
interrupções e os fundamentos das queixas; de igual modo, quando o mercador esquece seu
próprio interesse para traçar planos para o país, aproxima-se o período das visões e das quimeras,
assim como se dissolvem as bases sólidas do comércio. (FERGUSON, 1787, p. 240-241, tradução
livre)

No liberalismo clássico, a economia é uma ciência sem pretensões totais, mas, ao mesmo tempo, impõe a derrota à totalidade do soberano sobre os domínios essencialmente econômicos o soberano é parcialmente destituído do seu poder, diante da incapacidade de dominar os meandros do campo econômico (FOUCAULT, 2008a). No neoliberalismo - e especialmente no neoliberalismo americano -, pelo quadro já desenhado acima, vai-se um pouco além. Reconhecese que o Estado sempre governa demais. No entanto, para além disso, há uma difusão da ideia de que o campo propriamente econômico não possui limites. Ampliando-se a racionalidade de mercado, passa-se a produzir uma leitura econômica da vida, sendo evidente que, ao longo da segunda metade do século XX, a tecnologia dos preços passa a governar não apenas a própria lógica de funcionamento da economia, dirigindo-se por meio da técnica de acomodação dos preços as condutas distintas dos indivíduos em searas não exclusivamente ou não primordialmente econômicas (FOUCAULT, 2008a). O neoliberalismo implica que o capitalismo se torne o princípio organizador de tudo - uma totalidade transfigurada na imagem do indivíduo-corporação (GRAEBER, 2011).

No mundo das finanças pós-Bretton Woods, em que o poderio estatal norte-americano foi reforçado por meio do fim da conversibilidade dólar-ouro, essa concepção encontra seu cenário mais adequado de desenvolvimento. Como já referido, é nesse contexto, propulsor dos regimes 
cambiais flutuantes, que se viabiliza uma financeirização da vida, em que todo elemento da realidade social pode ser quantificável sob a forma de um ativo financeiro. Nesse contexto,

"a economia" apregoa sua pretensão de representar a atividade mais importante da sociedade
contemporânea, aquela cuja legitimidade particular lhe permitiria impor sua lei a todas as outras.
Essa arrogância decorre, certamente, da importância tomada pelos mercados financeiros,
artefatos sociais de um tipo particular, que ajudam em muito as finanças a se colocar como uma
potência "autônoma" frente à sociedade. Em um mundo dominado pelas finanças, a vida social
em quase todas as suas determinações tende a sofrer as influências daquilo que Marx designa
como a forma mais impetuosa de fetichismo. Com as finanças, tem-se "dinheiro produzindo
dinheiro, um valor valorizando-se por si mesmo, sem que nenhum processo (de produção) sirva
de mediação aos dois extremos". Uma vez que "o capital parece ser a fonte misteriosa (...) de seu
próprio crescimento", os proprietários de títulos financeiros, beneficiários de juros e de
dividendos, consideram que o "capital" deles vai fornecer-lhes uma receita "com a mesma
regularidade que a pereira dá pêras". (CHESNAIS, 2001, p. 8-9)

Esse desenvolvimento foi articulado, do ponto de vista das operações econômicas, a partir da crise que teve lugar em 1973, por ocasião da elevação unilateral dos preços do petróleo pelos países da Organização dos Países Exportadores de Petróleo (OPEP). Com o ingresso extraordinário de recursos derivados da venda de petróleo, os países que concentravam a maior produção injetaram no sistema financeiro, já coordenado pelos bancos privados norte-americanos, um enorme volume de divisas, possibilitando um incremento imediato da liquidez bancária ${ }^{6}$. Como relata David Harvey, "Nova York tornou-se o centro financeiro da economia global, o que, associado à desregulação interna dos mercados financeiros, permitiu que a cidade se recuperasse de sua crise e florescesse até o ponto da incrível opulência" (HARVEY, 2013, p. 58). O aumento da liquidez bancária viabilizou a ampla difusão de mecanismos financeiros, permitindo-se o acesso rápido, fácil e barato - em razão das baixas taxas de juros - a indivíduos e a instituições das mais variadas espécies.

A geração de commodities em torno dos distintos processos da vida social permitiu, inclusive, que o poder financeiro fosse utilizado para disciplinar resistências sociais, desarticuladas por meio do incremento do desemprego e da desarticulação sindical (HARVEY, 2013). Ao mesmo tempo, assistiu-se a um espetacular crescimento dos ativos circulantes, o que permitiu aos Estados Unidos bancar os custos da Guerra do Vietnã (GRAEBER, 2011) - a guerra apresenta-se como princípio organizador do poder político - e assumir o protagonismo do controle das finanças

\footnotetext{
${ }^{6}$ Como mostra Rabah Benakouche, "os recursos da Opep eram integrados ao sistema financeiro internacional sob a forma de empréstimos e investimentos. Eram apenas títulos que, na melhor das hipóteses, poderiam ser transferidos de um portador para outro, sem nenhum prejuízo econômico para o sistema financeiro estadunidense e mundial" (BENAKOUCHE, 2013, p. 67).
} 
globais. Tratava-se de dinheiro fictício, disponibilizado por meio de operações de crédito que implicavam a geração de juros sobre o capital.

Diante desse quadro, Estados por todo o mundo passaram a se endividar, engajando-se no estímulo às atividades especulativas. Como não seria difícil de notar, isso gerou vulnerabilidades nas economias nacionais, de modo que "o capital financeiro passou ao centro do palco (...), tendo podido exercer certo poder disciplinar tanto sobre os movimentos da classe operária como sobre as ações do Estado, em particular quando e onde o Estado assumiu dívidas de monta" (HARVEY, 2013, p. 59). O que se assistiu, a partir de então, foi um inédito processo do endividamento como um vetor das políticas governamentais e, dessa maneira, como elemento indispensável da governamentalidade que a partir de então se instituiu.

\section{2 $O$ endividamento recente da Argentina.}

É nesse momento que países como a Argentina iniciam uma espiral sem precedentes de endividamento, cuja dimensão pode ser verificada no seguinte gráfico, a ilustrar que uma dívida daquele país, que, em 1974, correspondia a pouco mais de 5 bilhões de dólares, multiplicou-se por nove no período de dez anos:

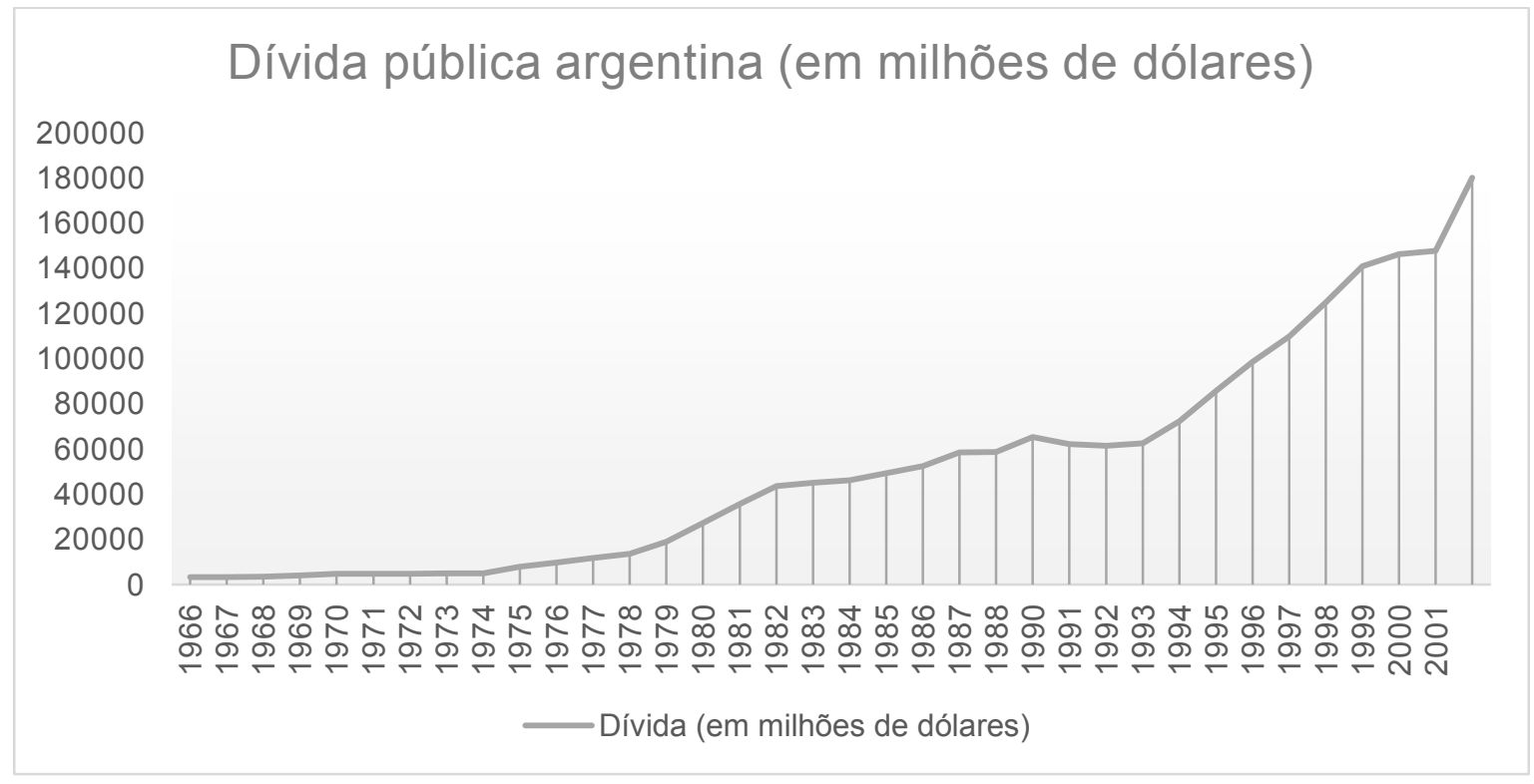

Gráfico 1 - Dívida pública argentina (em milhões de dólares). Fonte: Ministério da Economia da República Argentina (www.mecon.gov.ar). Elaboração própria. 
Antes de 1976, o endividamento público argentino flutuava em valores entre $10 \%$ e 15\% do PIB (DAMILL; FRENKEL; RAPETTI, 2005), o que garantia relativo conforto fiscal ao país. O período que se estendeu de 1977 a 1982, na Argentina sob a ditadura civil-militar ali instituída, foi uma fase de grande abertura ao capital estrangeiro, em que se articularam os pressupostos neoliberais de desregulamentação dos mercados e a imposição de um papel de agente financeiro ao Estado. É um tempo em que também se conjugam uma forte economia dos gastos sociais e um elevado grau de endividamento, destinados a garantir condições de crescimento econômico e, ao mesmo tempo, assegurar o próprio pagamento dos credores (MANZO; SALVA, 2012). Ainda nessa etapa, observa-se uma massiva fuga de capitais, da ordem de 23 bilhões de dólares, associadas a ganhos de juros não repatriados, estimados em mais de 30 bilhões de dólares (DORNBUSCH, 1988).

Ao final da década de 1970, e até o início dos anos 1980, assistiu-se a um acentuado crescimento da dívida, também provocado pelo aumento unilateral das taxas internacionais de juros incidentes sobre os valores cobrados dos países que se aproveitaram do momento inicial de liquidez bancária. Nesse processo, também foi determinante a absorção, pelo setor público, de parcela relevante da dívida externa privada (DAMILL; FRENKEL; RAPETTI, 2005).

Após o término da ditadura civil-militar, sucedeu-se uma desaceleração no crescimento da dívida argentina. Se no curto intervalo entre 1980 e 1982 a dívida cresceu 10\% (em paridade do poder de compra), no período compreendido entre 1982 e 1990, a taxa de crescimento foi quase idêntica (DAMILL; FRENKEL; RAPETTI, 2005).

A adesão da Argentina ao Consenso de Washington, após 1990, com a eleição de Carlos Menem para a presidência do país, teve severas implicações para as contas nacionais. Mesmo com o haircut promovido por intermédio do Plano Brady, o endividamento argentino deu um salto superior a 30\% (em paridade do poder de compra) entre 1990 e 2001 . As operações de crédito passaram, então, a representar um peso cada vez mais significativo sobre as riquezas produzidas no país, como demonstra o gráfico a seguir: 


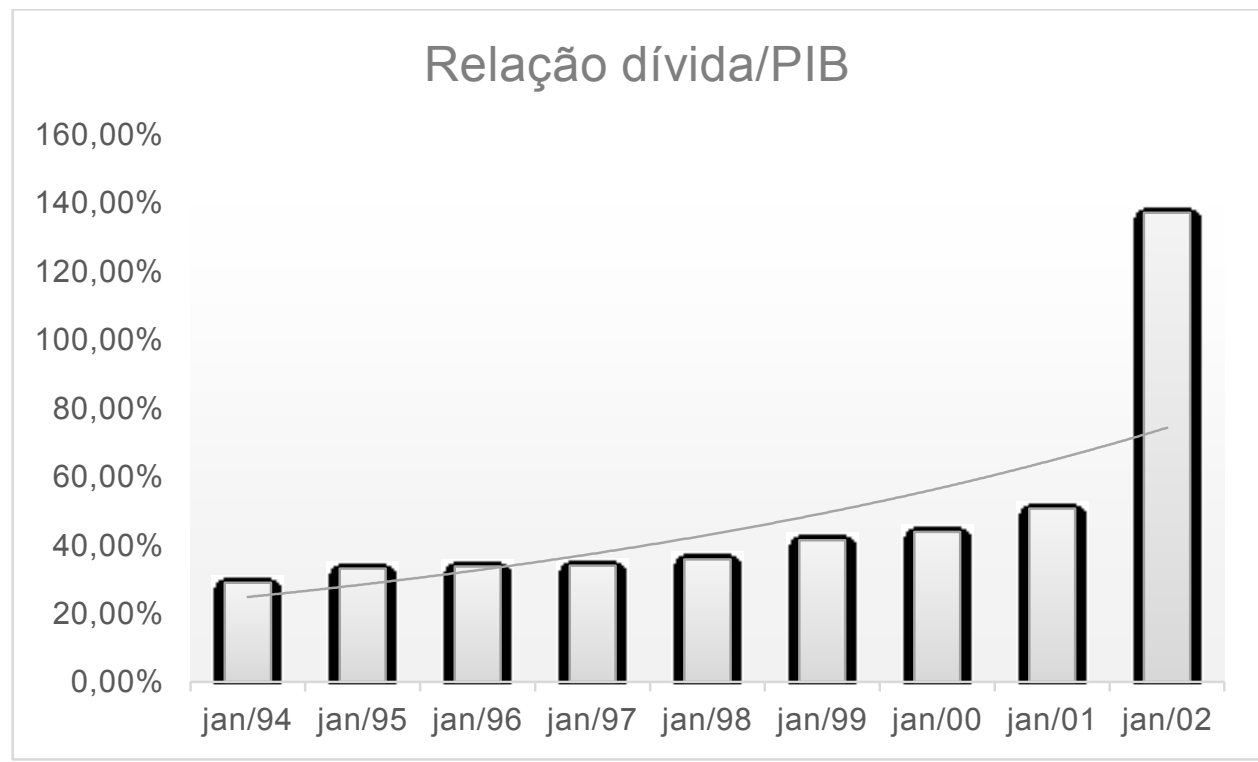

Gráfico 2 - Dívida pública argentina em função do PIB. Fonte: Ministério da Economia da República Argentina (www.mecon.gov.ar). Elaboração própria.

Nem se diga que o processo decorreu de arroubos dispendiosos da Argentina. Na verdade, o que se observa no início dos anos 1990 é uma drástica redução do déficit público, que cai de 7\% do PIB ao ano, em média, na década de 1980, para menos de 1\% do PIB entre 1991 e 1994. Além disso, diversas reformas liberalizantes, cujas condições estavam postas pelo mindset já referido neste capítulo, foram empreendidas durante o governo Menem. Todo o sistema de seguridade social público foi reestruturado, com privatização de parcela relevante. Além disso, promoveu-se uma ainda maior abertura ao comércio internacional, mediante a artificial valorização do peso (DAMILL; FRENKEL; RAPETTI, 2005).

Embora tenha seguido à risca o receituário neoliberal, a Argentina experimentou o amargo sabor dessas medidas. Ao lado das instabilidades econômicas que se difundiram no mundo capitalista ao longo da segunda metade da década de 1990 (México em 1995, Sudeste Asiático em 1997, Brasil em 1998, Rússia em 1999), a desproteção econômica gerada pelas políticas adotadas pelo governo Menem - em especial a forte dolarização da economia e a manutenção artificial da paridade cambial, que degradou as reservas do país - implicou uma espiral de crise, cuja principal expressão consistiu no forte incremento da dívida pública nacional. Essa dívida se compunha, agora, também de uma parte expressiva de empréstimos decorrentes dos resgates obtidos junto a órgãos multilaterais, como o Fundo Monetário Internacional (FMI).

Em 1999, após a eleição do novo presidente, Fernando de la Rúa, o governo nacional aderiu a uma visão que responsabilizava equívocos da gestão fiscal - e não os desequilíbrios 
cambiais e a vulnerabilidade financeira - pela crise então vivenciada. Colaborou, para tanto, a imposição de condicionalidades fiscais por intermédio dos acordos de resgate patrocinados pelo FMI. Tratou-se de uma concepção que conduziu o país a um forte aperto fiscal, cujo resultado imediato foi uma drástica recessão econômica (DAMILL; FRENKEL; RAPETTI, 2005).

Entre 2000 e 2001, com a Argentina afundada em crise, o governo do país tomou medidas que buscassem mitigar os efeitos financeiros dos ajustes anteriores, mas elas não tiveram o sucesso esperado, tendo por resultado apenas um alívio temporário bastante efêmero.

Durante os anos de 2000 e 2001, o governo tentou complementar as medidas fiscais com algumas
iniciativas no front financeiro. Para tanto, obteve apoio estrangeiro e implementou importantes
trocas de dívida [debt swaps] buscando convencer o público de que não existia risco de default.
Assim, no fim dos anos 2000, um importante pacote de resgate interno e externo, no valor de
cerca de 40 bilhões de dólares, foi anunciado: a blindaje. O FMI liderou a operação, aportando
uma extensão de 13,7 bilhões de dólares relativa a um crédito em stand-by desde março de 2000.
Agentes locais (um grupo de bancos e fundos de pensão privados) também tiveram participação
significativa. O efeito benéfico dessa ação teve vida muito curta. Dois meses após o anuncia, e
seguindo a erupção de uma nova crise na Turquia, o risco-país começou a escalar novamente.
(DAMILL; FRENKEL; RAPETTI, 2005, p. 56)

A essa primeira iniciativa de contenção dos efeitos financeiros do endividamento, seguiram-se outras duas relevantes medidas, que consistiram em trocas voluntárias de dívida, implementadas em julho (o chamado megacanje) e em novembro de 2001. As operações, no entanto, não foram suficientes para conter a espiral da crise. Os saques bancários se multiplicaram, prejudicando a liquidez interna e, no começo de dezembro de 2001, o governo foi levado a decretar o chamado corralito, que consistiu na restrição às movimentações financeiras e à retirada de dinheiro das poupanças. Com isso, objetivava-se, de um lado, preservar uma integridade mínima do sistema bancário, e, de outro, manter o estoque de reservas, evitando-se a desvalorização cambial e o desmanche do sistema de convertibilidade dólar-peso (DAMILL; FRENKEL; RAPETTI, 2005).

A essa altura, já haviam se desencadeado diversos movimentos populares contra as restrições econômicas impostas pelo governo. O aprofundamento da crise social levou à queda do governo de Fernando de la Rúa e à sucessão de governantes entre dezembro de 2001 e janeiro de 2002. Nos poucos dias da gestão do presidente Rodríguez Saa, eleito indiretamente pelo Congresso da Nação Argentina, decretou-se a moratória da dívida. Divergências internas no gabinete governamental acabaram por levá-lo à renúncia. Saa foi sucedido por Eduardo Duhalde, também eleito indiretamente. Sua primeira medida foi a adoção de uma lei de emergência, por meio da qual se abandonou a convertibilidade dólar-peso e se determinou que, enquanto os créditos seriam 
pesificados pela regra 1 peso $=1$ dólar, os depósitos seriam convertidos à razão 1 peso $=0,40$ dólar (CONDE, 2003).

Apesar do cenário de instabilidade social, política e econômica, a economia argentina rapidamente recuperou uma curva ascendente, contrariando, de um lado, as previsões pessimistas que poderiam ser derivadas do fim da paridade monetária ou da suspensão dos pagamentos de parte das obrigações financeiras e, de outro lado, as previsões advindas do Fundo Monetário Internacional. De fato, como destacam Damill, Frenkel e Rapetti, "muitas das políticas que desempenharam um papel importante durante a recuperação argentina tiveram que lidar com a oposição do FMI” (DAMILL; FRENKEL; RAPETTI, 2005, p. 59, tradução livre). Os autores destacam, entre elas, a imposição de controles de capital, o estabelecimento de impostos de exportação, a política monetária flexível e as intervenções do Banco Central para impedir uma valorização acentuada do peso. À época, acreditava-se que a Argentina pagaria um preço muito alto por seu default, o maior da
história para um Estado soberano devedor; e acreditava-se que essa punição continuaria por
alguns anos. Tal crença persistiu durante os anos que se seguiram, e é encontrada até hoje. No
entanto, a economia argentina contraiu-se por apenas três meses após o default. A perda de PIB
durante três meses foi abrupta (cerca de 5\%). O tamanho da perda é comparável, por exemplo,
com aquela que ocorreu na economia mexicana após a crise do peso de $1994-1995$ (cerca de $6 \%$
do PIB). Mas não existem evidências que demonstrem que esse decrescimento tenha se devido
ao default, uma vez que também poderiam decorrer dos efeitos da desvalorização cambial. A
economia real começou a se recuperar quando o sistema financeiro ainda vivenciava a desordem.
(WEISBROT; SANDOVAL, 2007, p. 3, tradução livre)

O retorno do crescimento econômico, alcançado também por meio de estímulos à demanda agregada, às exportações e ao comércio local, não seria possível, no entanto, sem um reajuste na política governamental com respeito ao endividamento público. Os juros anuais que a Argentina deixou de pagar em razão do default representavam entre 9 e 11 por cento do PIB - o equivalente à metade da arrecadação tributária do país (DAMILL; FRENKEL; RAPETTI, 2005). Não é demais concluir que isso foi indispensável para o retorno da capacidade de investimento de agentes públicos e privados, por meio de contínuos estímulos decorrentes da poupança gerada pela suspensão dos pagamentos.

Obviamente, um default, nos parâmetros morais há muito cristalizados em nossa cultura - especialmente em uma economia de natureza capitalista -, não pode resistir tanto tempo sem uma acirrada oposição dos credores. A Argentina precisava voltar a pagar sua dívida. No entanto, a dinâmica política interna do país também exigia que se formulasse um plano de continuidade do crescimento, caso se desejasse restaurar alguma estabilidade institucional. 
Ao mesmo tempo, o governo precisava lidar com o fato de que, se comparados os dados de antes e de depois do default, a dívida havia crescido consideravelmente, especialmente porque boa parte das perdas do sistema de crédito foi absorvida pelo Estado no ano de 2002, e também em virtude da transferência de dívidas das províncias para o governo central. A dívida saltou de 53,7\% para 166,4\% do PIB no período de um ano (WEISBROT; SANDOVAL, 2007).

A saída enxergada para a conciliação de interesses tão conflitantes foi a reestruturação da dívida pública ${ }^{7}$, especialmente da dívida em títulos, os quais eram portados por particulares de todo o globo. Isso se daria mediante a troca de dívidas [debt swap] antigas por novos títulos, cujos vencimentos eram programados pelo governo argentino a fim de que se obtivesse uma maior folga fiscal. Após uma resistência inicial dos credores e dos organismos multilaterais, o ano de 2004 trouxe um cenário internacional favorável à Argentina:

No final de 2004, a evolução dos mercados financeiros internacionais inesperadamente começou a jogar a favor da oferta argentina. A liquidez global estimulou o apetite por risco, que se converteu em uma demanda crescente pelos mercados de dívida emergentes e em uma redução do risco-país de países em desenvolvimento. Nesse novo contexto, o swap parecia mais atrativo. $\mathrm{O}$ valor atualizado dos títulos oferecidos, calculado com o desconto viabilizado pelas novas condições financeiras (...) era de cerca de 30 a 35 centavos de dólar por dólar. Isso representava uma redução [haircut] de 65\% a 70\% do valor da dívida. (DAMILL; FRENKEL; RAPETTI, 2005, p. 73)

A troca de dívida antiga por novos títulos se iniciou no ano de 2005 e a aceitação da proposta abrangeu quase $80 \%$ dos credores. A medida viabilizaria a continuidade dos investimentos no país, especialmente porque uma parte bastante relevante da nova dívida foi emitida em pesos, conferindo maior estabilidade ao valor devido e reduzindo a dependência de flutuações dos mercados internacionais. Com isso, o estoque da dívida foi reduzido em mais de 67 bilhões de dólares (DAMILL; FRENKEL; RAPETTI, 2005). A receita para a busca de uma recuperação econômica interna estava dada:

A recuperação da Argentina não foi conduzida por exportações ou pela elevação dos preços das commodities, mas antes - excetuando-se nos seis primeiros meses - pela demanda doméstica. Também não foi entravada pelos investimentos diretos estrangeiros cada vez mais baixos $-1,4 \%$ do PIB entre 2003 e 2007 - que geralmente são considerados nos círculos de políticas públicas e midiáticos como a pedra de toque de uma estratégia de crescimento para os países de baixos e médios rendimentos. O mais importante, talvez, tenha sido o fato de o governo ter se mantido firme nas negociações da reestruturação de sua dívida em default. Isso foi importante, tanto para ativar as políticas de crescimento, quanto para evitar a drenagem de recursos e outras consequências negativas para o clima de investimentos, promovida por uma maior carga da dívida. Se o default não é uma opção para a maioria dos países, os custos da moratória argentina se mostraram muito inferiores ao que se propagandeou. Da mesma forma, a recuperação argentina

\footnotetext{
${ }^{7}$ A reestruturação da dívida pública se define como "qualquer mudança, ocorrida durante um default ou sob a ameaça de default, nos pagamentos originalmente acordados da dívida" (STURZENEGGER; ZETTELMEYER, 2006, p. 3).
} 
não parece ter sido impedida por seu acesso reduzido aos mercados internacionais de crédito, o que vai de encontro aos argumentos típicos dos círculos acadêmicos, segundo os quais o rating do crédito soberano de um país é considerado um fator muito importante para a sua perspectiva de crescimento econômico. Olhando em retrospectiva, parece claro que o governo tomou a decisão correta ao priorizar sua recuperação econômica mais imediata, em lugar de satisfazer os credores estrangeiros e os mercados financeiros internacionais. (WEISBROT; SANDOVAL, 2007, p. 14-15)

Uma parcela minoritária - embora significativa - dos credores não aceitou a proposta do governo argentino. Nada além do esperado, em uma questão que envolvia centenas de milhares de credores em todo o mundo. Ainda antes da aprovação do plano de reestruturação da dívida argentina, credores se organizaram para inviabilizar o sucesso da proposta do Estado, destacandose o Global Commitee of Argentine Bondholders (GCAB), a Argentina Bond Restructuring Agency (ABRA), a American Task Force Argentina (ATFA) e a Interessensgemeinschaft Agentinien e.V. (WAIBEL, 2011).

Após o fechamento da janela para troca de títulos antigos por títulos novos, a arena econômica cedeu lugar ao início de inúmeras disputas jurídicas em torno da questão da reestruturação da dívida argentina. Sentindo-se preteridos, credores deram partida em processos nos seus respectivos países, todos demandando da República Argentina o pagamento integral dos valores devidos com base nas condições originalmente pactuadas. Dados da Securities and Exchange Commission dão a dimensão do problema jurídico que se anunciava: 158 processos iniciados nos Estados Unidos (inclusive 18 ações coletivas), 13 processos na Itália, 596 processos na Alemanha e 1 processo no Japão. Além disso, a Argentina foi sucessivamente acionada perante o órgão de resolução de controvérsias do Banco Mundial (International Centre for Settlement of Investment Disputes - ICSID), constituindo-se mais de 30 mesas de arbitragem em torno da matéria (REPÚBLICA ARGENTINA, 2010). Somente em um dos casos levados ao ICSID, 170 mil credores italianos acionaram a Argentina, no conhecido caso Beccara, envolvendo quantia de 5,5 bilhões de dólares (WAIBEL, 2011, p. 18-19).

Para os fins específicos deste trabalho, no qual se buscam as repercussões constitucionais das medidas relatadas no presente tópico, interessam particularmente três decisões de cortes constitucionais sobre a matéria do endividamento público argentino: aquelas proferidas nos tribunais da Itália, da Alemanha e dos Estados Unidos. Exposto o contexto fático sobre o qual se projetaram essas decisões, passa-se a uma exposição dos meandros processuais e dos elementos textuais de interesse no corpus documental selecionado. Trata-se da segunda etapa da pesquisa, a exploração do material. 


\section{EXPLORAÇÃO DO MATERIAL - DECISÕES JUDICIAIS ANALISADAS.}

\subsection{Decisão da Corte de Cassação da Itália (Luca Borri v. Repubblica Argentina)}

O advogado Luca Borri adquiriu, em junho de 2001, a importância de 183 mil euros em títulos global bonds emitidos pela Argentina. Os títulos, cuja aquisição foi intermediada por uma carteira de bancos comerciais italianos nos mercados secundários internacionais, venceriam em abril de 2008 e, de acordo com o que previsto quando emitidos, em 1998, renderiam juros anuais de $8,125 \%$. Após a decretação do default pela Argentina, o credor ajuizou ação civil perante o juízo de paz de Firenze, que determinou o pagamento imediato dos valores devidos, com fundamento no artigo 1186 do Código Civil Italiano, o qual prescreve:

Artigo 1186 - Decadência do termo

Ainda que o termo seja estabelecido em favor do devedor, o credor pode exigir imediatamente a prestação, se o devedor se tornar insolvente ou se diminuiu, por fato próprio, as garantias que tenha dado, ou ainda, se der as garantias que havia prometido ${ }^{8}$.

A decisão de primeiro grau compreendeu que, uma vez que a Lei $\mathrm{n}^{\mathrm{o}} 25$, de 2002, da República Argentina, declarou a "emergência pública em matéria social, econômica e financeira”, estaria configurada a situação de insolvência do país. Em face dessa decisão, a Argentina interpôs recurso, baseada nos seguintes argumentos (CORTE SUPREMA DI CASSAZIONE, 2005):

- As iniciativas judiciárias de Luca Borri se voltariam, exclusivamente, à satisfação de pretensões individuais, de modo unilateral, à revelia de centenas de milhares de portadores dos mesmos títulos, que haviam aceitado a reestruturação.

- A Argentina seria detentora de imunidade de jurisdição, por aplicação do princípio par in parem non habet jurisdictionem.

- $\mathrm{O}$ art. 22 do regulamento dos títulos em discussão reservava às cortes argentinas e de Nova Iorque a competência para julgar as controvérsias relativas àqueles títulos.

\footnotetext{
${ }^{8}$ Tradução livre do original:

"Art. 1186 - Decadenza dal termine

Quantunque il termine sia stabilito a favore del debitore, il creditore può esigere immediatamente la prestazione se il debitore è divenuto insolvente o ha diminuito, per fatto proprio, le garanzie che aveva date o non ha dato le garanzie che aveva promesse $(1274,1299,1313,1844,1850,1867$ e seguente, 1877, 2743)”.
} 
- Inexistiria, na legislação italiana, qualquer previsão de submissão da controvérsia à jurisdição italiana, como se poderia verificar da leitura da Lei n. 218, de 1995, sobre Direito Internacional Privado.

Em resposta, o credor buscou afastar a preliminar de incompetência da jurisdição italiana suscitada pela Argentina, tomando por base os seguintes argumentos (CORTE SUPREMA DI CASSAZIONE, 2005):

- A relação estabelecida entre credor e devedor, nesse caso, seria de natureza privada, não cabendo falar em normas de jus imperii, uma vez que, ao colocar em mercado seus títulos da dívida pública, a Argentina desenvolveria atividade de gestão.

- O art. 22 do regulamento do título seria irrelevante em face dos direitos supostamente violados pelo Estado-credor.

- A jurisdição italiana poderia ser respaldada mediante a aplicação do disposto no art. $3^{\circ}$, item 2, da Lei n. 218 , de $1995^{9}$, e pelo art. $5^{\circ}$, item 1, da Lei n. 804, de $1971^{10}$, ambos a implicar os termos da Convenção de Bruxelas de 1968, relativa à competência judiciária e à execução de decisões em matéria civil e comercial no âmbito da Comunidade Econômica Europeia.

O caso foi submetido à decisão da Corte Suprema de Cassação da Itália, que já de início firmou que

1. Na presente decisão - em que, relativamente à conhecida questão dos títulos argentinos, não se vislumbra envolvimento de qualquer sujeito (instituição intermediária ou autoridade reguladora) de nacionalidade italiana, mas única e exclusivamente a República Argentina -, impõe-se a questão preliminar de competência, a saber, se existe imunidade de jurisdição daquele Estado relativamente à responsabilização requerida na presente causa.

2. A questão é resolvida mediante a aplicação do princípio de direito consuetudinário internacional, recepcionado pelo ordenamento italiano em virtude do artigo 10 da Constituição, a respeito da "imunidade restrita ou relativa".

Em razão desse princípio, a imunidade de jurisdição civil dos Estados estrangeiros é limitada aos atos jure imperii (àqueles atos por meio dos quais se efetua o exercício das funções públicas estatais) e não se estende, por outro lado, aos atos jure gestionis ou jure privatorum (é dizer, aqueles atos que possuem caráter privatístico, praticados pelo Estado independentemente do seu poder soberano, como se fosse um cidadão privado (...).

\footnotetext{
${ }^{9}$ Artigo $3^{\circ}$ (2), da Lei n. 218, de 1995: A jurisdição italiana subsiste, ainda, com base no critério estabelecido nas seções 2, 3 e 4 do título II da Convenção sobre a Competência Jurisdicional e a Execução das Decisões em Matéria Civil e Comercial, bem como no seu protocolo, firmados em Bruxelas, em 27 de setembro de 1968, executados em conjunto com a Lei n. 804, de 21 de junho de 1971, com suas sucessivas modificações vigentes na Itália, sempre que se trate de matéria regida por aquela Convenção, mesmo quando o requerido não seja domiciliado no território de um Estados signatários. (tradução livre)

${ }^{10}$ Artigo $5^{\circ}$ (1), da Lei n. 804, de 1971: O requerido com domicílio no território de um Estado signatário pode ser demandado em outro Estado signatário: (...) Em matéria contratual, perante o tribunal do lugar onde a obrigação que serve de fundamento ao pedido foi ou deva ser cumprida... (tradução livre)
} 
- Isso equivale a dizer que, para que se verifique a imunidade de jurisdição do juízo nacional, é necessário que o exame e a investigação a respeito do mérito do pedido envolvam avaliações a respeito de atos ou comportamentos do Estado estrangeiro (...) que sejam expressões de seus poderes soberanos.

- Há, ainda, a limitação adicional (enfatizada mais recentemente, em razão do princípio fundamental do ordenamento internacional a respeito da obrigação de respeito aos direitos invioláveis da pessoa humana) de acordo com a qual o exercício da soberania também não resta coberto de imunidade quando se diga respeito a comportamento do Estado estrangeiro lesivo ao valor universal do respeito à dignidade humana, que transcende os interesses das comunidades nacionais isoladas (...) (ITÁLIA, 2005, tradução livre)

Assim, tratava-se de discutir, essencialmente, a existência ou não de imunidade de jurisdição que proteja os atos praticados pela República Argentina em face da demanda formulada pelo Sr. Luca Borri. A Corte de Cassação claramente optou por aplicar o direito costumeiro internacional, buscando respaldo no artigo 10 da Constituição da República Italiana, segundo o qual "o ordenamento jurídico italiano se conforma às normas gerais reconhecidas no direito internacional"11 . Fixa-se, igualmente, a premissa de que a imunidade de jurisdição é relativa. Dessa forma, somente é aplicável a atos de soberania (jure imperii), não se aplicando àqueles atos em que o Estado se comporte como um particular (jure gestionis), tampouco nas hipóteses em que constatadas graves violações aos "valores fundamentais da dignidade humana". Continua a Corte:

3. No caso sob exame, o caráter "relativo" da imunidade de jurisdição do Estado estrangeiro, em razão da impossibilidade de sua extensão aos atos jure gestionis, é, de fato, invocada pelo próprio recorrente, como fundamento para a afirmação da jurisdição italiana nas disputas com a República Argentina.

E o faz enfatizando que "a atividade desenvolvida por aquele Estado, por meio da colocação de títulos da dívida pública no mercado financeiro internacional que deveriam ser honrados sem atrasos quando dos respectivos vencimentos, constituía atividade econômica de mero direto privado, equiparável àquela desenvolvida por qualquer outro sujeito devedor que emita obrigações em troca de empréstimos e financiamentos recebidos dos investidores. Assim, não se pode permitir ao Estado estrangeiro subtrair-se da potestade do Estado nacional [ospitante], vez que aquela atividade não pode se configurar como manifestação de um poder soberano, obstativo do exercício do controle jurisdicional" (ITÁLIA, 2005, tradução livre).

No entanto, em que pesem as alegações suscitadas pelo credor, relatadas na decisão da

Corte de Cassação, as premissas são dissociadas das conclusões aferidas pelo Sr. Luca Borri, como se verifica no trecho a seguir:

4. Essa exposição da defesa, embora partindo de uma premissa correta, não pode conduzir a sua conclusão.

- Isso porque, a despeito da natureza inegavelmente privatística dos atos de emissão e colocação nos mercados internacionais das obrigações de que se trata, tal natureza não pode ser atribuída aos atos posteriores de declaração de moratória, adotados pelo governo argentino, dos quais, de

\footnotetext{
11 Tradução livre do original:

"Articolo 10

L'ordinamento giuridico italiano si conforma alle norme del diritto internazionale generalmente riconosciute. (...)"
} 
resto, o recorrente se vale para suscitar a decadência do termo, com base no art. 1186 do Código Civil, e, assim, obter a declaração de inadimplemento do Estado.

(...)

4.2. Tais atos [de moratória] (...) manifestam, evidentemente, o poder soberano do Estado.

E assim o é, seja por conta da sua natureza de leis orçamentárias (...), seja, sobretudo, pela já sublinhada finalidade por elas perseguida, eminentemente pública, relativa ao governo das finanças em função da tutela das necessidades primárias de sobrevivência econômica da população em um contexto histórico de grave emergência nacional.

4.3. Não muda a situação o fato de que tais leis incidem sobre direitos patrimoniais de cidadãos estrangeiros, uma vez que isso não configura o requisito da derrogação excepcional da imunidade de jurisdição que, como dito anteriormente, é arguível apenas quando existentes atos de exercício de soberania que se mostrem lesivos aos "valores universais da dignidade humana". Valores com os quais as leis referidas da República Argentina não se põem em conflito; na verdade, tendem a salvaguardar (ITÁLIA, 2005, tradução livre).

Desse extrato, podem ser destacadas as seguintes conclusões:

- A Corte Suprema de Cassação da Itália considerou como atos de gestão a emissão e o lançamento nos mercados dos títulos da dívida pública argentina.

- No entanto, os atos legislativos por meio dos quais se declarou a moratória do país e a situação de emergência nacional foram reconhecidos como atos de soberania, não sujeitos à apreciação pelo Poder Judiciário de outro país, à luz de suas normas internas.

- A natureza de atos de soberania é extraída, no caso sob análise, de dois fatos: (1) tratava-se de leis de natureza orçamentária, não sujeitas a controle; (2) a finalidade de referidas leis era de ordem pública - organizar a gestão das finanças públicas de modo a atender necessidades relevantes da população do país em um contexto de grave emergência nacional.

- Os direitos patrimoniais dos credores não são considerados como componentes do universo de valores afeitos à dignidade humana, cuja violação - ainda que por ato soberano - poderia ensejar a ativação da jurisdição externa.

- Por outro lado, considerou-se que as leis econômicas emergenciais aprovadas pela Argentina a partir de 2002 tinham por objetivo resguardar ditos valores fundamentais, o que resta de todo evidente em um trecho posterior do acórdão, segundo o qual "a proeminência absoluta dos interesses da coletividade organizada sob a forma de Estado (...) exclui a viabilidade de valoração das leis [de emergência] em termos de uma eventual violação do regime jurídico dos atos negociais por serem jure privatorum" (ITÁLIA, 2005, tradução livre). 


\title{
2.2 Decisão do Tribunal Constitucional Federal Alemão (Argentinien-Anleihen)
}

Perante o Poder Judiciário Alemão, a Argentina não teve semelhante sorte quando do julgamento da questão relativa ao dever de indenizar os credores que não aceitaram o plano de reestruturação da dívida pública. Milhares deles eram nacionais da Alemanha e ingressaram em juízo - vários por meio de associações que visavam unicamente defender os interesses de credores da dívida argentina - nas cortes desse país, especialmente naquelas localizadas em Frankfurt, principal centro financeiro alemão.

Diante da quantidade de casos submetida à jurisdição local, submeteu-se, no ano de 2003, questionamento constitucional ao Bundesverfassungsgericht sobre "se as regras de direito internacional impedem a condenação do réu" (BUNDESVERFASSUNGSGERICHT, 2007), no caso, a República Argentina. Posteriormente, a questão foi reformulada, para saber

\begin{abstract}
se o estado de necessidade declarado pelo réu, com respaldo na impossibilidade de pagamento, o legitima, por força do direito internacional, a recusar temporariamente o adimplemento de obrigações requeridas em juízo, e, caso se entenda apropriado, se existe uma regra geral de direito internacional que, nos termos do artigo 25 da Lei Fundamental, constitua um elemento do direito federal reconhecido como fonte de direitos e obrigações para o indivíduo (BUNDESVERFASSUNGSGERICHT, 2007, tradução livre).
\end{abstract}

A questão fora submetida porque, no entendimento da corte local, "as ações eram admissíveis e bem fundamentadas quanto aos pleitos principais, e tais pleitos somente poderiam ser afastados com base na aplicação de princípio de direito internacional proposta pelo réu, que, conforme se alega, justificaria a sua recusa de pagamento no estado de necessidade" (BUNDESVERFASSUNGSGERICHT, 2007, tradução livre). Note-se que, segundo as informações prestadas pela corte local, esta deixou de avaliar se efetivamente existia um estado de necessidade, por compreender que não tinha condições de julgar as consequências fáticas dessa circunstância.

O tema submetido ao Tribunal Constitucional alemão dizia respeito, portanto, à possibilidade de se excluir, mediante aplicação de norma geral de direito internacional relativa ao estado de necessidade, o dever da República Argentina de pagar integralmente e indenizar os credores em razão da suspensão de pagamentos da dívida pública. A discussão se dava, essencialmente, porque o artigo 25 da Lei Fundamental de Bonn prescreve que "as regras de direito 
internacional público são parte integrante do direito federal; sobrepõem-se às leis e constituem fonte direta de direitos e obrigações para os habitantes do território federal""12.

O Tribunal Constitucional requereu às partes que se pronunciassem. Os autores da ação alegaram, em síntese, que: (i) a Argentina, desde 2003, não se encontraria mais sob estado de necessidade, conforme comprovariam os dados do crescimento econômico do país; e (ii) o estado de necessidade, ainda que permanecesse, seria de responsabilidade exclusiva da Argentina. Por outro lado, a República Argentina alegou que:

- A exclusão do dever de pagar em razão do estado de necessidade seria uma regra de direito costumeiro internacional, conforme seria possível verificar nos trabalhos da Comissão de Direito Internacional da ONU, nos julgados da Corte Internacional de Justiça e na literatura relevante em matéria de responsabilidade dos Estados.

- Dever-se-ia aplicar a doutrina do estado de necessidade sempre que interesses de Estado relevantes estivessem em risco. Um desses interesses relevantes seria a manutenção solvência do país, indispensável para que o poder público alcançasse seus propósitos.

- Seria possível declarar o estado de necessidade por razões financeiras, as quais não decorreriam unicamente das condutas do Estado argentino, vez que, no atual sistema econômico, as finanças públicas dependeriam consideravelmente do contexto internacional.

- Os Artigos da Comissão de Direito Internacional sobre Responsabilidade dos Estados garantiriam a extensão da exceção decorrente do estado de necessidade às relações de natureza privadas. De igual maneira, alega-se que a jurisprudência de órgãos internacionais respaldaria a recusa de pagamento.

- A extensão da exceção referida aos contratos de natureza privada assinados pelo Estado seria decorrente, ainda, do fato de os títulos da dívida se converterem em obrigações internacionais, na medida em que gozariam de proteção diplomática.

O Tribunal Constitucional Federal acabou por concluir que "não é possível verificar, atualmente, uma regra de direito internacional que permita a um Estado recusar-se temporariamente a adimplir obrigações de direito privado devidas a indivíduos particulares por meio da invocação do estado de necessidade declarado por conta da impossibilidade de pagamento"

\footnotetext{
12 Tradução livre do original:

"Artikel 25 - Die allgemeinen Regeln des Völkerrechtes sind Bestandteil des Bundesrechtes. Sie gehen den Gesetzen vor und erzeugen Rechte und Pflichten unmittelbar für die Bewohner des Bundesgebietes”.
} 
(BUNDESVERFASSUNGSGERICHT, 2007, tradução livre). Para tanto, realizou as seguintes considerações:

1. O direito internacional não possui um direito da insolvência dos Estados uniforme ou codificado (...). Acordos internacionais individuais contêm cláusulas gerais de necessidade; no entanto, faz-se necessária uma interpretação caso a caso, para saber se elas se relacionam com emergências econômicas, assim como para que se verifiquem os pressupostos necessários do direito internacional e do direito privado para a invocação da necessidade quando do evento da insolvência. Consequentemente, as regras sobre as consequências da insolvência de um Estado são fragmentárias; ainda, tais regras somente ganham a autoridade de direito internacional se contidas no direito costumeiro internacional ou constituírem princípios gerais de direito.

2. A invocação do estado de necessidade é reconhecida no direito costumeiro internacional apenas nas relações jurídicas que estão sujeitas exclusivamente ao direito internacional; por outro lado, não há evidência de uma prática estatal baseada na conviç̧ão jurídica necessária (...) que estenda a justificativa legal para a invocação do estado de necessidade às relações entre credores regidas pelo direito privado. (BUNDESVERFASSUNGSGERICHT, 2007, tradução livre)

Disso, fica evidente que a corte constitucional alemã, de um lado, afirma não existir uma regra geral de direito internacional costumeiro que conduza à conclusão de que a insolvência de um Estado perante seus credores privados possa ser justificada pela emergência econômica em que se encontre. De outro lado, a decisão também se arvora na concepção de que isso se deve ao fato de que o estado de necessidade somente pode ser reconhecido como uma exceção de responsabilidade nas relações regidas exclusivamente pelo direito internacional, inexistindo "evidências" que estendam tal possibilidade a relações que, no entender da corte alemã, são regidas exclusivamente pelo direito privado.

Note-se que o tribunal não excluiu a possibilidade de reconhecimento, em abstrato, do estado de necessidade como uma regra geral de direito internacional costumeiro. Na verdade, até admite essa possibilidade, mediante a interpretação do art. 25 do Projeto de Artigos da Comissão de Direito Internacional sobre Responsabilidade Internacional dos Estados ${ }^{13}$. No entanto, entende que apenas são aplicáveis a relações que não digam respeito à interação Estado-indivíduo credor.

Fazendo alusão a decisões anteriores do CIADI que teriam desconsiderado os pleitos de Estados em prol da exceção decorrente do estado de necessidade, a corte alemã faz menção a uma

${ }^{13}$ Art. 25. Estado de necessidade.

1. Nenhum Estado pode invocar o estado de necessidade como causa de exclusão de ilicitude de um ato em desacordo com uma obrigação internacional daquele Estado, a menos que o ato:

a) seja o único modo para o Estado preservar um interesse essencial contra um perigo grave e iminente; e

b) não afete gravemente a um interesse essencial do Estado ou Estados em relação aos quais exista a obrigação, ou da comunidade internacional como um todo.

2. Em nenhum caso pode o Estado invocar o estado de necessidade como causa de exclusão de ilicitude se:

a) a obrigação internacional em questão exclui a possibilidade de invocar a necessidade, ou

b) o Estado contribuiu para a ocorrência do estado de necessidade. 
distinção no tratamento dos procedimentos de arbitragem internacional em relação aos casos tratados no âmbito das cortes submetidas à sua jurisdição constitucional. Na concepção do Bundesverfassungsgericht, a discussão sobre obrigações financeiras resguardadas por tratados bilaterais é sempre mediada pelos Estados, de modo que se estaria a tratar, nessa hipótese, de relação regida pelo direito internacional, não pelo direito privado.

O Centro Internacional para Arbitragem de Disputas sobre Investimentos, que atua como um tribunal e é parte da estrutura do Banco Mundial, já examinou diversas vezes a invocação da necessidade por Estados. Alguns peticionários desses procedimentos eram pessoas jurídicas de direito privado. A despeito disso, esses casos não fornecem indicativos da possibilidade de transferência de um pleito de estado de necessidade às relações regidas pelo direito privado. Uma distinção deve ser feita a respeito do fato de a violação de uma obrigação em razão da invocação do estado de necessidade estar relacionada a um tratado bilateral de investimento aplicável sob o regime de direito internacional ou a um contrato de direito privado entre o investidor e o Estado. Ambos podem, em princípio, estar ligados às competências do Centro Internacional para Arbitragem de Disputas sobre Investimentos. No entanto, os relevantes procedimentos que digam respeito ao estado de necessidade alegado quando do descumprimento de uma obrigação regida por tratados de investimentos bilaterais concluídos entre dois Estados, os quais podem ser qualificados como acordos internacionais, não são idênticos aos pleitos diretos formulados por um investidor sob o direito privado. (...) Uma obrigação violada que seja objeto de uma petição [perante o CIADI] não é devida ao requerente privado diretamente, mas ao Estado em que vive, embora o propósito protetivo do acordo tenha por destino final os interesses dos investidores privados. Direitos e obrigações de um Estado oponente, nesse caso, advêm de um acordo internacional que, via de regra, contém uma cláusula de necessidade; assim, esses direitos e obrigações emergem de uma relação governada pelo direito internacional. (BUNDESVERFASSUNGSGERICHT, 2007, tradução livre)

Assim também se entendeu em relação aos casos julgados por cortes constitucionais mencionados durante o julgamento. Em todos eles, concluiu-se que, ainda que aplicável a exceção do estado de necessidade, a relação estabelecida entre o Estado e seus credores era sempre mediada por relações diplomáticas. E mais: tratava-se de casos antigos, decididos em um período "no qual disputas judiciais diretas entre Estado e particulares eram virtualmente afastadas por conta do princípio da imunidade absoluta dos Estados, ainda largamente aplicado nos processos perante cortes nacionais, e indivíduos não podiam recorrer a instâncias internacionais" (BUNDESVERFASSUNGSGERICHT, 2007, tradução livre).

\subsection{Decisão da Suprema Corte dos Estados Unidos da América}

A mais notável discussão sobre as consequências jurídicas da moratória declarada pela Argentina e pela posterior reestruturação da sua dívida pública deu-se no Poder Judiciário dos Estados Unidos da América, chegando-se até a decisão final proferida pela Suprema Corte daquele país, cujas consequências ainda estão em marcha. 
Após o default, diversos fundos, principalmente alguns hedge funds, que abrigam investimentos especulativos de altíssimo risco, adquiriram títulos da dívida argentina nos mercados secundários. Essas organizações são usualmente conhecidas como fundos abutres [vulture funds], "em razão de suas táticas de investimentos e litigância judicial bastante agressivas" (SCHUBERT, 2013, p. 1098, tradução livre). Trata-se de uma forma de investimento de alto risco, na qual "uma instituição de investimentos que adquire dívidas soberanas inadimplentes no mercado secundário, geralmente com a intenção de litigar a fim de obter o valor integral do instrumento de dívida" (MUSE-FISHER, 2014, p. 1673, tradução livre).

Essa forma de atuação nos mercados financeiros é favorecida pelo fato de diversos Estados, em seus atos de emissão de títulos da dívida pública, renunciarem à imunidade de jurisdição que costuma lhes beneficiar e, ao mesmo tempo, transferirem às cortes de Nova Iorque a competência para decidir sobre eventuais litígios com os credores. Assim ocorreu com a dívida argentina. Veja-se o formato de um desses atos, o Decreto $\mathrm{n}^{\mathrm{o}} 319$, de 2004, por meio do qual a argentina executou um lançamento de títulos públicos no mercado:

Art. $8^{\circ}$ - Autoriza-se a renúncia de jurisdição em favor dos tribunais estaduais e federais localizados na cidade de NOVA IORQUE, ESTADOS UNIDOS DA AMÉRICA, e a renúncia a impor a defesa de imunidade soberana, incluída na Carta de Contratação ("Engagement Letter"), e sua emenda aprovadas pelo Artigo $7^{\circ}$ do presente decreto, estando preservada a negação de embargo em forma expressa com relação a: $(. . .)^{14}$

Para que se tenha uma dimensão mais exata das implicações dessa modalidade de investimento, o principal fundo que contende com a Argentina nas cortes norte-americanas, o NML Capital Ltd., adquiriu, nos mercados secundários, 105 milhões de dólares, mas acionou judicialmente a Argentina para que pagasse o equivalente, em valores atualizados, a 2,4 bilhões de dólares (SCHUBERT, 2013, p. 1098).

Após o ajuizamento de diversas ações nas cortes de Nova Iorque, elas foram reunidas e julgadas por um juiz federal da Corte Distrital do Distrito Sul de Nova Iorque, Thomas Griesa. Tinham por fundamento principal o fato de os títulos argentinos serem emitidos com uma cláusula de igual tratamento entre os credores - a denominada cláusula pari passu. Em dezembro de 2011, o juiz compreendeu que, ao pagar regularmente os credores que aceitaram os acordos de reestruturação e deixar de pagar aqueles que não aceitaram, a Argentina incorreu em

\footnotetext{
${ }^{14}$ Tradução livre de:

"Art. $8^{\circ}$ - Autorízase la prórroga de jurisdicción a favor de los tribunales estaduales y federales ubicados en la ciudad de NUEVA YORK, ESTADOS UNIDOS DE AMERICA, y la renuncia a oponer la defensa de inmunidad soberana, incluida en la Carta de Contratación ("Engagement Letter") y su enmienda aprobadas por el Artículo $7^{\circ}$ del presente decreto, estando preservada la inembargabilidad en forma expresa con respecto a: (...)".
} 
comportamento discriminatório. Assim, em fevereiro de 2012, determinou-se que a Argentina deveria se abster de efetuar pagamentos aos credores que aceitaram a reestruturação enquanto não fossem igualmente pagos os que a recusaram (holdout creditors) (GRIESA, 2012).

A ordem judicial foi complementada em novembro do mesmo ano, para que se determinasse o imediato pagamento aos credores do grupo NML. No entanto, após a interposição de recurso da Argentina direcionado à Corte Federal de Apelações de Nova Iorque, a ordem foi suspensa, a fim de que aquele tribunal se debruçasse mais detidamente sobre a questão. Em março de 2013, demandou-se que Argentina apresentasse um plano de pagamento de seus credores. O país terminou por propor algo bastante parecido com a reestruturação de sua dívida datada de 2010, o que foi de pronto rejeitado pelos credores. Com isso, em agosto de 2013, a Corte de Apelações rejeitou o recurso argentino, reiterando que o país não demonstrara a falta de condições para efetuar o pagamento integral dos credores e afastando as alegações - que uniam os poderes executivos de Estados Unidos e Argentina - de que a confirmação da decisão do juiz Griesa ocasionaria um grave obstáculo a futuras renegociações da dívida de países em situação de crise (MUSE-FISHER, 2014).

Diante disso, a Argentina recorreu, por duas vezes, à Suprema Corte dos Estados Unidos, sustentando que a decisão da Corte de Apelações de Nova Iorque teria violado o Foreign Sovereign Immunities Act (FSIA) - lei norte-americana que garante imunidade de jurisdição e de execução aos países estrangeiros - uma vez que permitiria a busca de ativos do país, para fins de execução. O receio argentino era claramente justificável. Em junho de 2012, apoiados na primeira decisão do juiz Griesa, o fundo NML Capital obteve uma ordem judicial de busca e apreensão em Gana, para que fosse retido, como garantia da execução contra a Argentina, a fragata Libertad, pertencente a este país, que se encontrava atracada no porto de Tema, o principal do país africano (FONTEVECCHIA, 2012). A Argentina somente conseguiria liberar seu navio em dezembro daquele ano, quando o Tribunal das Nações Unidas sobre Direito do Mar reconheceu a imunidade de execução do navio, por se tratar de bem de natureza militar (ORGANIZAÇÃO DAS NAÇÕES UNIDAS, 2012).

Um pronunciamento favorável da Suprema Corte significaria, ainda, que os bens do Banco Central da Argentina direcionados aos bancos de Nova Iorque - recursos destinados ao pagamento dos credores que aceitaram os termos da reestruturação - fossem bloqueados para garantir a execução. 
Reconhecidos na qualidade de amici curiae, diversos países se manifestaram no sentido de que a manutenção das decisões de instâncias inferiores geraria um colapso nos sistemas de reestruturação de dívidas públicas dos países. Embora o caso da Argentina seja emblemático, dados do Fundo Monetário Internacional indicam a realização de cerca de 600 reestruturações de dívida em 95 países entre os anos de 1950 e 2010 (FUNDO MONETÁRIO INTERNACIONAL, 2012). Uma decisão contrária nos Estados Unidos - país que usualmente resolve as controvérsias judiciais entre credores e devedores das dívidas públicas - poderia desincentivar o aceite de propostas de reestruturação.

Esses argumentos, entretanto, não comoveram a Suprema Corte, que com larga maioria aprovou sua opinion negando o certiorari pretendido pela Argentina. O voto, preparado pelo conservador justice Antonin Scalia insistiu, basicamente, no ponto segundo o qual

O texto da lei [FSIA] confere aos Estados soberanos dois tipos de imunidade. A primeira, e mais significativa, "um Estado estrangeiro será imune da jurisdição das cortes dos Estados Unidos... exceto nos casos previstos nas seções 1605-1607” § 1604. Essa norma não é útil à Argentina, pois um Estado pode renunciar à imunidade de jurisdição § 1605 (a) (1), e nesse caso a Argentina o fez (...). Consequentemente, a lei [FSIA] torna a Argentina "sujeita à jurisdição da mesma maneira e na mesma extensão de qualquer indivíduo particular sob tais circunstânicas" § 1606. A segunda previsão de imunidade prevista na lei [FSIA] enuncia que "a propriedade de um Estado estrangeiro nos Estados Unidos" está sujeita a arresto, sequestro ou execução se (1) for "usada para uma atividade comercial nos Estados Unidos" $§ 1610$ (a), $e$ (2) em algumas outras exceções enumeradas, como no caso de renúncia $\S 1610$ (a) (1)-(7). (...)

Não existe uma terceira previsão proibindo ou limitando a busca, para garantia da execução, de ativos de um Estado soberano no exterior. (SUPREME COURT OF THE UNITED STATES, 2014)

Ao assim decidir, a Suprema Corte dos Estados Unidos da América terminou por abrir caminho para a busca judicial de bens a executar em todo o mundo e, embora silente quanto à possibilidade de bloqueio de verbas do Banco Central argentino, possibilitou que fossem exaradas ordens de não pagamento a credores da dívida reestruturada sem que antes fossem satisfeitos os créditos não-reestruturados detidos pelos fundos abutres.

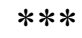

Exposta a documentação analisada, verificam-se algumas categorias que surgem como determinantes para a análise judicial da dívida pública argentina. Inicialmente, há uma recorrência do embate entre os termos soberania (e os demais a ele associados: jus imperii, discricionariedade, ordem pública) e gestão (e os demais a ele associados: direito privado, ato comercial). Além disso, 
a frequente invocação do estado de necessidade (ou de emergência) como fundamento para a exclusão da responsabilidade da Argentina resta patente, assim como a imunidade soberana do país.

As reflexões qualitativas que se seguem girarão em torno dessas unidades de registro, buscando depreender, ainda, os silenciamentos presentes nas decisões das cortes de competência constitucional que são objeto deste trabalho. 


\section{DO CONCEITO JURÍDICO DE SOBERANIA À PRÁTICA CONTEMPORÂNEA DA GESTÃO}

\subsection{Poder absoluto e perpétuo... de não tocar em nenhum contrato}

Tratar dos limites da soberania parece nos conduz fatalmente a paradoxos, visto que não podemos falar de modo consistente acerca dos limites de um poder ilimitado. Afirmar a existência de limites jurídicos para a soberania implica, desde o início, negar o caráter soberano do poder político. Porém, nem mesmo Jean Bodin, que nos oferece a canônica definição da soberania como poder absoluto e perpétuo, defendeu a ideia de que o poder político soberano seria absolutamente ilimitado, visto que ele não colocava em dúvida a necessidade de observar o direito natural e os ditames divinos. Por mais que a noção de soberania nas origens do pensamento político moderno aponte para a ausência de limites, o reconhecimento de que nenhum poder humano é absolutamente ilimitado acompanha essa formulação desde a sua gênese.

Esse caráter paradoxal da teoria clássica da soberania é ilusório, pois ele não decorre da articulação conceitual renascentista, e sim de nossa própria rearticulação contemporânea. A teoria de Bodin não nos leva a tratar dos limites do poder ilimitado, pois ela não trata abstratamente do poder, e sim dos governantes concretos. O governo pode ser exercido por pessoas dotadas de poder absoluto, no sentido restrito de que elas não reconhecem a existência de um governante com autoridade superior. Em momento algum, a soberania envolvia o poder de regular ex nihilo todas as relações humanas, mas apenas uma negação absoluta de subordinação a outras autoridades políticas. O reconhecimento da autoridade de Deus, da tradição, do direito natural ou dos costumes era plenamente compatível com essa construção, visto que esses elementos não constituem propriamente governantes (que poderiam ser soberanos), mas ordens jurídicas impessoais.

Como acentua De Rota, o governante medieval não era apenas um senhor de súditos, mas um "senhor de senhores" 15 . Tratava-se de uma ordem em que era plenamente compatível com a noção de governo o fato de que um duque era vassalo de rei e que um rei poderia ser vassalo de um imperador, pois os vassalos não governavam em nome do soberano nem eram seus súditos. A concentração de poderes nas mãos do monarca, que foi condição para a superação das guerras

\footnotetext{
15 “O feudalismo em concreto resultou de uma grande e peculiar composição de corpos e enunciações. Para que sua receita fosse efetiva, deveria ocorrer certa mescla oportuna e exata com o corpo da terra, com os corpos aldeães, com os caminhos, os mercados, as massas de impostos; com o corpo do vassalo, do servo, da aristocracia equestre e das guerras privadas; também com o corpo do soberano, que se converte, dessa forma, em um senhor de senhores". (DE ROTA, 2014, p. 26)
} 
religiosas desencadeadas pela reforma, inviabilizava a continuidade dessa relação, especialmente porque o novo soberano era o único senhor admitido dentro da unidade política: eles não eram senhores de senhores, pois os antigos vassalos foram reduzidos à condição de simples súditos. A redução das relações políticas ao binômio senhor/súdito gerou uma ordem centrada em uma única pessoa (o monarca), de modo que todos os outros indivíduos eram ligados entre si por sua comum subordinação ao mesmo governante. Nesse contexto, o caráter soberano do governante era identificado quando ele governava em nome próprio (e não em função de alguma espécie de delegação ou representação) e quando era legibus solutus, de modo que não poderia ser vassalo de ninguém (nem mesmo de um imperador) e que tampouco poderia ser eleito nem julgado por qualquer instituição.

A emergência de uma tal ordem envolveu a o desenvolvimento de uma nova concepção política acerca do corpo do soberano. A constituição dessa perspectiva se deu, em grande medida, a partir de uma formulação mística em torno da justificativa para se atribuir a um ser humano concreto o exercício de autoridade ilimitada sobre toda uma comunidade que lhe seria submetida. Na teoria política clássica e medieval, é frequente a utilização de uma versão orgânica do exercício do poder, em que a unidade política é entendida como um corpo funcionalmente diferenciado, no qual cada função é atribuída a determinados entes (MEZZANZANICA, 2011, p. 2, tradução livre).

Nesse contexto é que se torna possível falar na tese dos “dois corpos do Rei”, recuperada por Ernst Kantorovicz a partir dos chamados Relatórios Plowden a respeito das concepções jurídicas da natureza da figura régia. Esses relatórios - em que se apoiou o poder central inglês durante a era elisabetana e na dinastia Stuart - debruçaram-se sobre diversos casos judiciais em que se revelavam os fundamentos da autoridade do soberano no medievo britânico, quase sempre associada a figuras simbólicas que se embasavam na dupla caracterização da existência do Rei.

Os Dois Corpos do Rei, dessa forma, constituem uma unidade indivisível, sendo cada um inteiramente contido no outro. Entretanto, não pode haver dúvida em relação à superioridade do corpo político sobre o corpo natural. "Três reis [Henrique IV, V, VI] detiveram o Ducado de Lancaster em seu Corpo natural, o qual não é tão amplo e extenso quanto o outro, e o quarto [Eduardo VI] o deteve em seu Corpo político, o qual é mais amplo e extenso que o Corpo natural." Não somente o corpo político é "mais amplo e extenso" que o corpo natural, mas residem, no primeiro, certas forças realmente misteriosas que reduzem, ou até removem, as imperfeições da frágil natureza humana. (KANTOROVICZ, 1998, p. 23)

Mediante o apelo ao mito dos dois corpos é que se buscou conciliar o sagrado e o soberano, como aspectos unificados de uma mesma tradição política (KAHN, 2004). Kantorowicz rememora, como elemento indiciário dessa concepção, a história dos registros constantes na 
biblioteca do arcebispo Matthew Parker, morto em 1575, de coletâneas teológico-políticas escritas por um clérigo anônimo de origem normanda. Esses escritos continham, entre diversas outras considerações, teses a respeito da chamada persona mixta, quando um mesmo ser reunia distintas categorias, muitas vezes bastante distintas entre si. Entre as pessoas que assim poderiam ser identificadas, o "anônimo" normando identificou autoridades episcopais - como os bispos - e autoridades político-institucionais - como os reis. E são esses últimos que interessam especialmente, porque, no dizer de Kantorowicz, conquanto a doutrina papal lhes negasse a natureza clerical da autoridade, os últimos autores medievais acentuavam certa capacidade espiritual, que afastavam sua autoridade daquela de um mero leigo ${ }^{16}$.

Nos escritos do anônimo normando, percebe-se a pretensão de se caracterizar o rei a partir uma construção especular do Cristo (Rex imago Christi) - um ser que pode ser visualizado de duas formas distintas: "uma, natural ou individual, e a outra, consagrada ou (como o autor a chama) deificada e apoteosada" (KANTOROWICZ, 1998, p. 57). A aproximação com a imagem do Cristo dialético (síntese de um corpo natural e um corpo apoteótico) voltava-se, na obra de Kantorowicz, ao objetivo primordial de caracterizar o poder régio, em suas origens, como de índole acentuadamente supratemporal ${ }^{17}$. Isso fica evidente no seguinte trecho:

Foi nessa época que a "comunidade do reino" tornou-se consciente da diferença entre o rei como senhor feudal pessoal e o rei como administrador supra-individual da esfera pública - uma esfera pública que inclúa o fisco que "nunca morria" e era perpétuo porque nenhum tempo corria contra ele. O pensamento religioso, que havia influenciado profundamente, ou mesmo determinado, os conceitos de governo em uma fase anterior, foi transferido para a nova órbita dos negócios públicos de maneira aparentemente grosseira - mediante a comparação da sempiternidade do fisco com a eternidade de Deus ou de Cristo. (KANTOROWICZ, 1998)

\footnotetext{
16 "Não só o bispo, mas também o rei figurava como uma persona mixta, porque lhe era atribuída uma certa capacidade espiritual como emanação de sua consagração e unção. É verdade que a doutrina papal definitivamente negava ao rei um caráter clerical, ou relegava esse caráter a alguns títulos honorários e funções insignificantes. Entretanto, os últimos autores medievais continuavam a enfatizar que o rei 'não era meramente leigo', ou, na linguagem jurídica, 'não era uma pessoa comum"” (KANTOROWICZ, 1998, p. 50).

${ }^{17}$ Essa pretensão foi diagnosticada, anos após a publicação de Dois corpos..., por Giorgio Agamben, que qualificou como inócua a tentativa de Kantorowicz de desmistificar a teologia política a partir da investigação de uma genealogia do caráter supratemporal ou perpétuo da soberania. Para Agamben, a ritualística investigada por Kantorowicz seria melhor aproveitada como um indício da arqueologia do outro atributo da soberania em sua acepção clássica ("puissance absolue et perpétuelle") - a natureza absoluta. "Com respeito à interpretação de Kantorowicz e Giesey, a doutrina dos dois corpos do rei surge, então, sob uma luz diversa e menos inócua. Se a sua relação com a consagração imperial pagã não pode mais ser posta entre parênteses, é o próprio sentido da teoria que muda radicalmente. O corpo político do rei (que, nas palavras de Plowden, 'não pode ser visto ou tocado' e, 'privado da infância e da velhice e de todos os outros defeitos ao qual está sujeito o corpo natural', magnifica o corpo mortal unindo-se a este) deriva, em última análise, do colosso do imperador; mas, justamente por isto, ele não pode representar simplesmente (como julgavam Kantorowicz e Giesey) a continuidade do poder soberano, mas também e antes de tudo o exercente de vida sacra do imperador que, através da imagem, é isolada e elevada aos céus no ritual romano, ou transmitida ao sucessor no rito inglês e francês. Mas, com isso, o sentido da metáfora do corpo político volta-se, de símbolo da perpetuidade da dignitas a cifra do caráter absoluto e não humano da soberania" (AGAMBEN, 2007, p. 108).
} 
No entanto, como posteriormente aludiu Giorgio Agamben, os mesmos fatos especialmente aqueles do qual decorre a análise de Kantorowicz a respeito das cerimônias fúnebres dos reis franceses - poderiam ser aproveitados para demonstrar o nascedouro de um outro atributo da soberania: o seu caráter absoluto. De fato, para Agamben, "as fórmulas le mort saisit le vif e le Roi ne meurt jamais devem ser compreendidas de modo muito mais literal do se costuma pensar: no momento da morte do soberano, é a vida sacra, na qual se baseava seu poder, que investe a pessoa do sucessor" (AGAMBEN, 2007, p. 108). Na morte do rei, revela-se o que o corpo soberano excede a sua vida natural e humana - mostra-se a sua eternidade na exata medida em que, tratandose de um poder absoluto, ele não pode ser sacrificável. É um poder absoluto, expresso como transmissão da vontade divina. Essa multiplicação de corpos que anula o paradoxo de um poder absoluto e eterno exercido por uma pessoa mortal, pois se os atributos do sagrado não podem ser compatibilizados com a limitação de um corpo físico, eles são plenamente compatíveis com o corpo metafísico de um rei cuja pessoa é o núcleo de um sistema de governo que o transcende.

Como é comumente reproduzido, Jean Bodin forneceu a clássica definição da soberania como "o poder absoluto e perpétuo de uma república" (BODIN, 1997, p. 47, tradução livre). De acordo com o autor, trata-se de um poder perpétuo, porque "não é limitada, nem em poder, nem em responsabilidade, nem em tempo" (BODIN, 1997, p. 49, tradução livre). Por outro lado, consiste em um poder absoluto porque não está sujeito a nenhuma forma superior de normatividade, nem mesmo aquela por si atribuída àqueles a quem se impõe o seu poder. "É necessário que quem seja soberano não esteja de nenhum modo submetido ao império de outro e possa dar a lei aos súditos e anular ou emendar as leis inúteis; isso não pode ser feito por quem está sujeito às leis ou a outra pessoa" (BODIN, 1997, p. 52-53, tradução livre). Esse poder, como tal não pode advir de outra fonte que não aquela que lhe seja capaz de atribuir toda a potência sobre a determinação de outros corpos não-soberanos ${ }^{18}$.

\footnotetext{
${ }^{18} \mathrm{O}$ raciocínio de Bodin pode ser bem exemplificado no trecho a seguir, em que reflete sobre a natureza eletiva do cargo de Rei da França no período capetíngio: "A única razão aparente para presumir que o reino da França tenha sido eletivo seria a forma observada na consagração real, antes de que se preste juramento. Os bispos de Laon e Beauvais, ao tempo em que levantam o rei, perguntam ao povo presente se aceita o rei; recebido o consentimento de toda a audiência, o arcebispo de Reims lhe toma o juramento... Aqueles que afirmam que os reis são eleitos pelos Estados esquecem que o arcebispo de Reims pretendia a titularidade exclusiva de tal direito... Pretensão, por outra parte, impossível e incompatível com a fé e a homenagem que os arcebispos de Reims prestam ao rei da França... Devido a tudo isso, costuma-se dizer neste reino que o rei não morre jamais [le roy ne meurt jamais], antigo provérbio que vem a pôr em relevo como o reino nunca foi eletivo. O rei não recebe seu cedro do papa, tampouco do arcebispo de Reims, nem do povo, mas direta e exclusivamente de Deus" (BODIN, 1997).
} 
Conforme descrevem Antonio Negri e Michael Hardt, trata-se, na Baixa Idade Média, de um período no qual ocorre uma verdadeira revolução. Os elementos transcendentais fortes da religião passam a conviver, de modo cada vez mais acentuado, com a afirmação dos poderes mundanos. "Seres humanos se declararam donos da própria vida, produtores de cidades e de história e inventores de céus", descobrem-se agentes da imanência (HARDT; NEGRI, 2000, p. 89). Esse processo, que nas ciências naturais acaba por implicar a vocação transformadora da teoria em práxis, manifesta-se no âmbito propriamente político como um "processo de refundação da autoridade com base num universal humano e pela ação de uma multidão de singularidades" (HARDT; NEGRI, 2000, p. 91). Por outro lado, a descrição oferecida do período feudal expõe diferentes fontes de dominação, múltiplas organizações de poderes que se apoiam uns sobre os outros e dos quais se tornou possível extrair a forma da soberania, não como elemento de conformação de dada unidade, mas como aparato definidor de estratégias globais (FOUCAULT, 1999, p. 51-52).

É nesse contexto de remanejamento da soberania para um âmbito propriamente mundano que a guerra começa a aparecer como fundamento analítico das relações de poder e de justificação do Estado. De imediato, é o nome de Thomas Hobbes que surge como representativo desse modo particular de análise. O teórico é explícito ao demonstrar sua concepção das motivações para o surgimento de uma comunidade política, vista como uma castração da liberdade original:

A causa final, finalidade e desígnio dos homens (que amam naturalmente a liberdade e o domínio sobre outros), ao introduzir aquela restrição sobre si mesmos sob a qual vemos viver em repúblicas, é a precaução com a própria conservação e com uma vida mais satisfeita. Quer dizer, o desejo de sair daquela mísera condição de guerra, que é consequência necessária (...) das paixões naturais dos homens, quando não há um poder visível capaz de os manter em respeito e os forçar, por medo do castigo, ao cumprimento dos seus pactos e à observância das leis de natureza (...). (HOBBES, 2003, p. 59)

O contrato inicial, o ano-zero da comunidade política hobbesiana não envolve derramamento de sangue. Não é um ato de violência, mas resultado de um cálculo racional de possibilidades que equilibra a liberdade igualitária original e o receio que emerge da potencialidade do terror. O eventual colapso do governo abre espaço para uma guerra civil cujos resultados potenciais são tão catastróficos que qualquer pessoa deveria preferir a continuidade da ordem, mesmo de uma ordem na qual não goza de uma situação particularmente feliz. Nos termos de Antón Fernández de Rota, trata-se de uma concreta “economia do temor: é necessário o pacto, já que por sua natureza, todos os homens são igualmente pequenos e frágeis" (DE ROTA, 2014, p. 71) frente a situações nas quais inexista um poder político organizado. 
Como qualifica Foucault, “o que caracteriza o estado de guerra [em Hobbes] é uma espécie de diplomacia infinita de rivalidades que são naturalmente igualitárias" (FOUCAULT, 1999, p. 106). Essa diplomacia do medo é o motor de formação e de manutenção da sociedade civil hobbesiana, pois "a fundação não é, portanto, um evento que se cumpre de uma vez por todas in illo tempore, mas é continuamente operante no estado civil na forma da decisão soberana" (AGAMBEN, 2007, p. 115). Ora, se a sociedade civil é fruto de um acordo determinado pelos cálculos racionais de seres portadores de paixões (em especial, de seres portadores de medo), ela somente pode ser produto da ação humana direta. É necessário recordar, por outro lado, que a sociedade civil se constitui na medida em que ela estabelece uma pessoa jurídica (o Estado) competente para governar o corpo social, garantindo a vida e a segurança dos indivíduos. Eis a concepção clássica do Leviatã:

A única maneira de instituir um tal poder comum, capaz de defendê-los das invasões dos estrangeiros e das injúrias uns dos outros, garantindo-lhes assim uma segurança suficiente para que, mediante seu próprio labor e graças aos frutos da terra, possam alimentar-se e viver satisfeitos, é conferir toda sua força e poder a um homem, ou a uma assembléia de homens, que possa reduzir suas diversas vontades, por pluralidade de votos, a uma só vontade. O que equivale a dizer: designar um homem ou uma assembléia de homens como representante de suas pessoas, considerando-se e reconhecendo-se cada um como autor de todos os atos que aquele que representa sua pessoa praticar ou levar a praticar, em tudo o que disser respeito à paz e segurança comuns; todos submetendo assim suas vontades à vontade do representante, e suas decisões a sua decisão. Isto é mais do que consentimento, ou concórdia, é uma verdadeira unidade de todos eles, numa só e mesma pessoa, realizada por um pacto de cada homem com todos os homens, de um modo que é como se cada homem dissesse a cada homem: Cedo e transfiro meu direito de governar-me a mim mesmo a este homem, ou a esta assembléia de homens, com a condição de transferires a ele teu direito, autorizando de maneira semelhante todas as suas ações. Feito isto, à multidão assim unida numa só pessoa se chama Estado, em latim civitas. É esta a geração daquele grande Leviatã, ou antes (para falar em termos mais reverentes) daquele Deus Mortal, ao qual devemos, abaixo do Deus Imortal, nossa paz e defesa (HOBBES, 2009, p. 61).

Mas não é somente de medo que derivam esses acordos. A teoria política hobbesiana traz para o plano mundano uma economia que antes pertencia exclusivamente ao domínio do sagrado ou do cósmico. Transforma-se em uma economia política do Estado, cuja razão é explicada em termos contratuais de uma troca de exercício soberano do poder por segurança na realização de direitos intimamente ligados às necessidades de desenvolvimento de uma economia burguesa. A base dessa economia é sustentada no tripé egoísmo-desconfiança-glória ${ }^{19}$.

\footnotetext{
19 "Das três causas de conflito que Hobbes apresenta, Macpherson grifa a primeira (os homens se batem pelo ganho), dela infere a segunda (... por desconfiança) e desconhece a terceira (... por glória). A guerra é apenas a continuação da economia burguesa por seus próprios meios, desmedidos. Assim, a verdadeira continuidade irá do estado político ao seu passado mítico, à condição natural, que dele se infere: comum a ambos é a tensão, que se exprime em diferentes registros do medo" (RIBEIRO, 2004, p. 24).
} 
Assim é que, em Hobbes, o Estado se desvincula de uma origem mística e passa a ser percebido como conjugação de vontades racionais. Em claro rompimento com a filosofia política de base clássica, o Estado, a civitas, a polis, em Hobbes, são elementos decorrentes da convenção original, e não subprodutos de leis naturais. Trata-se de uma alteração também relacionada com a possibilidade epistemológica de ação para a transformação - "nessas origens da modernidade, (...) o conhecimento passou do plano transcendente para o plano imanente, e, por conseguinte, esse conhecimento humano tornou-se um fazer, uma prática de transformar a natureza" (HARDT; NEGRI, 2001, p. 90). Do mesmo modo, os seres humanos deixam de ser vistos como naturalmente políticos; "sua associação depende de acordos que observem a justiça entre os homens que discordam sobre quem deve receber o quê, e que, portanto, precisam de padrões comuns sobre o certo e o errado para regular suas relações" (RYAN, 1996, p. 216, tradução livre).

Nesse novo contexto de uma economia de trocas políticas, a affectio é substituída pela conjunção entre potestas e auctoritas, expressas ambas por meio da central figura da soberania. No novo modelo da análise do poder estatal, "é a relação entre o bom rei e os súditos o que desaparece: o monarca não é mais cabeça do corpo político (a soberania é ‘alma': princípio de vida), e governar já não é amar" (RIBEIRO, 2004, p. 45). Com isso, não se trata de um construto teórico orgânicofuncional em que cada parte exerce sua atividade de modo autônomo, submetendo-se à suprema vontade de um príncipe. O complexo orgânico só existe porque tem uma alma - a soberania. $\mathrm{O}$ exercício da soberania, obviamente conjugado com as paixões provenientes do medo, dá-se mediante uma representação conformadora do corpo político:

A soberania hobbesiana altera a imagem do corpo político; este se concebia como agregado de partes, cada uma com direitos próprios, não podendo a cabeça substituir um membro ou este supri-la; as teorias medievais do contrato reconheciam, ao príncipe e aos cidadãos, direitos distintos e inarredáveis. Hobbes, porém, não mais diz que é cabeça do body politic o rei; afirma que a soberania - resida num indivíduo ou numa assembleia - é sua alma, invisível sopro movendo o corpo todo. Pois é pouco relacionar o soberano com seus súditos somente pelo medo; tal paixão, aliada da aversão, sozinha não funda a representação. Para que esta surja, e não a simples opressão, requer-se também um apetite, que se traduz como esperança. São os movimentos desses gêmeos discordes que constituem a vida; e esta, no corpo político, é a soberania do representante (RIBEIRO, 2004, p. 54).

A despeito do seu exercício mediante representação, na teoria política hobbesiana, a soberania mantém-se como elemento portador do absoluto, razão de interferência direta do soberano sobre os corpos dos súditos. "Non est potestas super terram quae comparetur ei" (Jó, 41:24) - não há poder sobre a Terra que se lhe possa comparar, enuncia o frontispício do Leviatã. O poder soberano é o Deus mortal, traduz em Terra o absoluto divino. Ao súdito não é dado arguir 
um direito contra o exercício soberano da força, pois, do contrário, agiria contra si mesmo e, consequentemente, contra as leis da natureza. A soberania está acima dos direitos estabelecidos pelo soberano. Contempla, por isso, até mesmo o poder de vida e de morte:

Portanto, a liberdade dos súditos está apenas naquelas coisas que, ao regular suas ações, o soberano permitiu: como a liberdade de comprar e vender, ou de outro modo realizar contratos mútuos; de cada um escolher sua residência, sua alimentação, sua profissão, e instruir seus filhos conforme achar melhor, e coisas semelhantes. Não devemos todavia concluir que com essa liberdade fica abolido ou limitado o poder soberano de vida e de morte. Porque já foi mostrado que nada que o soberano representante faça a um súdito pode, sob qualquer pretexto, ser propriamente chamado injustiça ou injúria. Porque cada súdito é autor de todos os atos praticados pelo soberano, de modo que a este nunca falta o direito seja ao que for, a não ser na medida em que ele próprio é súdito de Deus, e consequentemente obrigado a respeitar as leis de natureza. Portanto pode ocorrer, e freqüentemente ocorre nos Estados, que um súdito seja condenado à morte por ordem do poder soberano, e apesar disso nenhum deles ter feito mal ao outro. (HOBBES, 2009, p. 74)

Mais à frente, Hobbes deixa evidente que é a própria existência da sociedade civil que depende da manutenção do direito de vida e de morte:

Dado que a preservação da sociedade civil depende da justiça, e que a justiça depende do poder de vida e de morte, assim como de outras recompensas e castigos menores, que compete aos detentores do Estado, é impossível um Estado subsistir se qualquer outro, que não o soberano, tiver o poder de dar recompensas maiores do que a vida, ou de aplicar castigos maiores do que a morte. (HOBBES, 2009, p. 146)

Desses trechos, no entanto, percebe-se uma mitigação bem destacada por Michel Foucault, séculos mais tarde: o chamado direito de vida e de morte não é uma prerrogativa simétrica em seus dois elementos (o par vida/morte). De fato, trata-se de um direito positivo quanto à morte (o soberano decide sobre o encerramento da vida do súdito), e negativo quanto à vida (o soberano se abstém de retirá-la do súdito). É que, mesmo quando se fala em uma "recompensa de vida", esta se refere à vida eterna, da qual não dispõe o soberano (ele é Deus mortal) ${ }^{20}$.

Os efeitos decorrentes da prerrogativa da soberania, em que pese tal mitigação, não deixam de ser dramáticos - a vida dos súditos, a mesma que se objetivou tutelar mediante o ingresso comum dos indivíduos na sociedade civil, está à disposição do soberano, para que este possa atingir os seus fins de soberania. O poder de determinar a morte não se desgarra do conceito de império na teoria hobbesiana, não é à livre vontade dos cidadãos em comunidade que se refere a decisão soberana. Ela tem uma referência imediata à vida sacrificável desses indivíduos que abriram mão da sua liberdade original. Isso leva Agamben a mencionar que a vida dos cidadãos, em Hobbes,

\footnotetext{
20 "O soberano só exerce, no caso, seu direito sobre a vida exercendo seu direito de matar ou contendo-o; só marca seu poder sobre a vida pela morte que tem condições de exigir. O direito que é formulado como 'de vida e de morte' é, de fato, o direito de causar a morte ou de deixar viver". (FOUCAULT, 2014, p. 146)
} 
surge, assim como o elemento político originário, o Urphänomenon da política: mas esta vida não é simplesmente a vida natural reprodutiva, a zoé dos gregos, nem o bios, uma forma de vida qualificada; é, sobretudo, a vida nua do homo sacer e do wargus, zona de indiferença e de trânsito contínuo entre o homem e a fera, a natureza e a cultura. (AGAMBEN, 2007, p. 115).

Essa concepção, diga-se, não foi exclusividade do pensamento hobbesiano, que acabou de servir de base para os teóricos do absolutismo real. Ele foi notado, de igual forma, também em teses que ampararam concepções políticas de base democrática, como aquela construída por JeanJacques Rousseau. Ao desenvolver uma concepção baseada na existência de uma vontade geral que tudo pode, Rousseau reitera os atributos elementares da soberania moderna - ela é absoluta e indivisível, organicamente transmutada na concepção de uma "convenção do corpo com cada um de seus membros" (ROUSSEAU, 2007, p. 41). E, para manter essa tese, precisa recorrer a um contorcionismo retórico capaz de justificar a totalidade da soberania - expressa, uma vez mais, pela disposição do poder soberano sobre a vida dos súditos.

Pergunta-se: não tendo os particulares direito de dispor da própria vida, como podem transmitir ao soberano esse direito que não têm? Esta questão, somente por estar mal posta parece difícil de se resolver. Todo homem tem o direito de arriscar a própria vida para a manter. Já disseram talvez que quem se lança pela janela, para escapar de incêndio, seja culpado de suicídio? Imputou-se tal crime ao que perece numa tempestade, cujo perigo não ignorava ao embarcar? $\mathrm{O}$ fim do tratado social é a conservação dos contratantes: quem quer o fim que também os meios, que são inseparáveis de alguns riscos e até de algumas perdas. Quem quer conservar a vida à custa dos outros deve também dá-la quando for preciso; o cidadão já não é juiz do perigo a que a lei o quis expor e, quando o príncipe lhe diz: convém ao Estado que morras, ele deve morrer, pois só com essa condição viveu até então em segurança, e a sua vida já não é só um benefício da natureza, senão um dom condicional do Estado. (ROUSSEAU, 2007, p. 42-43)

Uma tal percepção da soberania, como um absoluto domínio sobre a disponibilidade da vida dos cidadãos, poderia conduzir à conclusão imediata de que a teoria do Estado de base contratualista implicaria a totalização desse mesmo Estado contra outros instrumentos ou dispositivos de poder presentes em sociedade. Mas, nesse jogo, o Estado não está sozinho. O desenvolvimento da teoria da soberania dessacralizada não pode ser desvinculado, afinal, do contexto histórico de desenvolvimento do capitalismo e tampouco de certos valores morais presentes desde muito tempo nas sociedades que gestaram o mundo ocidental. De fato, como destacam Hardt e Negri:

Existe, na base da moderna teoria de soberania (...) outro elemento muito importante - um conteúdo que preenche e sustenta a forma da autoridade soberana. Esse conteúdo é representado pelo desenvolvimento capitalista e pela afirmação do mercado como fundamento dos valores de reprodução social. Sem esse conteúdo, que é sempre implícito, e sempre trabalha dentro do aparelho transcendente, a forma de soberania não teria sobrevivido na modernidade, e a modernidade europeia não teria alcançado posição hegemônica em escala mundial. (HARDT; NEGRI, 2001, p. 103) 
Em sentido semelhante, David Graeber identifica nas mudanças ocorridas nos costumes europeus - também motivadas pelas disputas políticas então verificadas - elementos que facilitaram a emergência da articulação entre soberania e capitalismo. O dinheiro, instrumento que já atuava em favor do estabelecimento de poderes políticos, precisava de uma nova lógica de governo que se adaptasse às reformulações por que passava o sistema de organização das finanças. No contexto de formação dos estados nacionais europeus, impostos deviam ser pagos obrigatoriamente em metal, os quais, inevitavelmente, passaram ao controle de poucas mãos banqueiros, grandes comerciantes, governos centrais. Por outro lado, os negócios cotidianos eram realizados por meio de operações de crédito que já ocorriam durante a Baixa Idade Média - por exemplo, por meio da emissão de títulos de crédito. A cada vez maior concentração de metais preciosos em poucos agentes econômicos permitiu a estes que exercessem um grande domínio sobre os fluxos econômicos, determinando-se os meios de troca que seriam admitidos para a troca por metais - indispensáveis ao recolhimento de impostos. Mas a imposição de um tal regime precisava de um poder fortemente organizado ${ }^{21}$.

Para tanto, contribuíram, ainda, mudanças no plano da religião, especialmente com a ascensão do protestantismo. Para além do conhecido apoio à usura prestado por Calvino, veja-se o exemplar construto de Zwingli para legitimar a conduta moral da geração de dívidas mediante a cobrança de juros:

O reformista protestante suíço Zwingli era ainda mais explícito. Deus, ele dizia, nos deu a lei divina: amar nosso vizinho como a nós mesmos. Se nós realmente cumpríssemos essa lei, os humanos dariam gratuitamente as coisas uns aos outros, e a propriedade privada não existiria. No entanto, como destacado por Jesus, o ser humano nunca conseguiu viver sob esse padrão puramente comunístico. Portanto, Deus nos deu uma segunda lei, inferior, uma lei humana, a ser aplicada [enforced] pelas autoridades civis. Uma vez que essa lei inferior não nos pode compelir a agir do modo como nós realmente deveríamos agir ("o magistrado não pode forçar alguém a emprestar o que possui sem que esse alguém espere recompensa ou lucro") -, pelo menos ele pode nos fazer seguir a lição do apóstolo Paulo, que disse: "Pague todos os homens a quem você deve". (GRAEBER, 2011, p. 339-340, tradução livre)

\footnotetext{
21 "Essa foi uma batalha política, ainda que também fosse uma discussão conceitual sobre a natureza do dinheiro. O novo regime de dinheiro baseado em metais preciosos somente poderia ser imposto por meio de uma violência praticamente sem precedentes - não somente no além-mar, mas também dentro das metrópoles. Na maior parte da Europa, a primeira reação à 'revolução do preço' e aos cercamentos de terras comuns não foi muito diferente do que aconteceu recentemente na China: milhares de camponeses abandonando ou sendo forçados a sair de suas vilas para se tornarem mendigos ou 'homens livres', um processo que culminou em insurreições populares. A reação dos governos europeus, contudo, foi totalmente diferente. As rebeliões foram reprimidas e, dessa vez, não foram feitas concessões. Mendigos foram reunidos, enviados para colônias como trabalhadores contratados e alistados nos exércitos e marinhas nacionais" (GRAEBER, 2011, p. 330, tradução livre).
} 
Como é possível verificar, todos esses discursos tornam possível a conexão entre o uso do poder de imposição de condutas pelo Estado (legal enforcement), a estruturação do sistema econômico e a emergência de padrões morais. No âmbito específico da moderna teoria da soberania, o indício da aludida articulação está justamente na figura central da passagem do estado de natureza para o estado societal no qual a soberania tem o papel de maior relevo. Essa figura é o contrato.

Em Hobbes, seria possível identificar três leis básicas da natureza ${ }^{22}$ : em primeiro lugar, parece evidente que se deve buscar a paz e a segurança. Em segundo lugar, que se deve renunciar a uma parcela dos direitos naturais para que haja paz e segurança. A terceira lei, de especial interesse para a presente discussão, consiste em que os contratos devem ser respeitados ${ }^{23}$. Essa lei natural, expressão reformulada do antigo pacta sunt servanda, poderia ser compreendida a partir da necessidade original de um pacto de segurança - uma vez que eu renuncio ao meio direito original de me armar contra os meus concidadãos, preciso da garantia de que estes façam o mesmo (RYAN, 1996). Sendo esta uma lei natural, conquanto não pudesse ser arguida pelos cidadãos em oposição ao soberano, consistia em um dever deste agir de modo a garantir seu cumprimento. É para se garantirem os contratos que o soberano deve, por exemplo, recolher impostos e, assim, manter as forças de segurança capazes de assegurar o gozo dos direitos pactuados:

Aquele que transfere qualquer direito transfere também os meios de gozá-lo, na medida em que tal esteja em seu poder. Por exemplo, daquele que transfere uma terra se entende que transfere também a vegetação e tudo o que nela cresce. Também aquele que vende um moinho não pode desviar a corrente que o faz andar. E daqueles que dão a um homem o direito de governar soberanamente se entende que lhe dão também o direito de recolher impostos para pagar a seus soldados, e de designar magistrados para a administração da justiça. (HOBBES, 2009, p. 50)

Mesmo sob a fórmula de Bodin, já se reconhecia ser necessário distinguir entre leis e contratos. Bodin afirmava que, no caso das chamadas leis convencionadas, mesmo o príncipe soberano permanecia a elas obrigado, estando horizontalmente posicionado em relação ao súdito

\footnotetext{
${ }^{22}$ Em Hobbes, uma lei da natureza "é um preceito ou regra geral, estabelecido pela razão, mediante o qual se proíbe a um homem fazer tudo o que possa destruir sua vida ou privá-lo dos meios necessários para preservá-la, ou omitir aquilo que pense poder contribuir melhor para preservá-la. Porque embora os que têm tratado deste assunto costumem confundir jus e lex, o direito e a lei, é necessário distingui-los um do outro. Pois o direito consiste na liberdade de fazer ou de omitir, ao passo que a lei determina ou obriga a uma dessas duas coisas. De modo que a lei e o direito se distinguem tanto como a obrigação e a liberdade, as quais são incompatíveis quando se referem à mesma matéria" (HOBBES, 2009, p. 47).

23 "Daquela lei de natureza pela qual somos obrigados a transferir aos outros aqueles direitos que, ao serem conservados, impedem a paz da humanidade, segue-se uma terceira: Que os homens cumpram os pactos que celebrarem. Sem esta lei os pactos seriam vãos, e não passariam de palavras vazias; como o direito de todos os homens a todas as coisas continuaria em vigor, permaneceríamos na condição de guerra" (HOBBES, 2009, p. 52).
} 
com quem pactuadas. O elemento moral justificador da imperatividade dessa conduta era evidente: "A palavra do príncipe deve ser como um oráculo; este perde a sua dignidade quando nos merece tão má opinião que não lhe podemos acreditar se não jurar, ou se não cumpre sua promessa quando recebe dinheiro em troca" (BODIN, 1997, p. 54-55). O crédito, como se verifica, já se posiciona, naquela teorização, como um dos elementos que, ao lado da lei divina, não se encontra à disposição do príncipe absoluto. Isso porque parecia evidente, para Bodin, que os contratos eram instrumentos de celebração da amizade, princípio supremo de justiça natural e fundamento de existência da sociedade civil (BODIN, 1997).

Todo aquele que, por alguma razão, inclusive por motivos de crédito, dependa de algum outro sujeito, não pode ser classificado como soberano. No dizer de Bodin, "somente é absolutamente soberano quem não depende em nada de outro, já que o vassalo de qualquer feudo que seja, ainda que seja imperador ou papa, deve um tributo pessoal em razão do feudo que tem" (BODIN, 1997, p. 70). Essa dependência impediria, aos olhos do autor, o exercício do atributo supremo da soberania: o poder de editar e anular as leis, no qual se compreendem todos os demais atributos - declarar a guerra e fazer a paz, rever os juízos dos magistrados, instituir e destituir oficiais, poder de tributar e conceder subsídios, outorgar graça e anistia, entre outros (BODIN, 1997, p. 75).

O problema teórico se torna insolúvel apenas quando Rousseau desloca a soberania do governo para o povo, atribuindo soberania a uma pessoa abstrata e inaugurando o problema de uma vontade política que não reconhecia o primado de qualquer ordem: não se tratava mais da soberania de um governo exercida em nome do direito natural de uma tradição política, mas de uma soberania legisladora que não reconhecia qualquer ordem superior. Essa teoria não representa uma continuidade da teoria clássica cristalizada nas obras de Bodin e Hobbes, mas a sua ruptura. Enquanto na teoria clássica a soberania era o conceito fundamental para justificar a concentração do poder político em um governo unificado, a teoria da soberania popular era utilizada para justificar a possibilidade da ruptura revolucionária da ordem política, sob o argumento de que o governo nunca poderia ser soberano, visto que ele se constituía em um conjunto de magistrados instituídos pelo povo e que, a qualquer momento, poderiam ter seu poder anulado pelo povo que lhes conferiu sua atribuição.

É por conta da limitação que o contrato impõe à soberania que um teórico como Rousseau declara expressamente que a instituição de um governo não pode jamais ser considerado como 
resultante de um contrato entre o povo e os governantes, que estabeleça para as pessoas o dever de obedecer aos governantes. Não é possível que o povo faça um contrato com certas pessoas particulares, atribuindo a elas o direito de governar, pois "é evidente que esse pacto do povo com estas ou aquelas pessoas seria ato particular, donde se infere que esse contrato não poderia ser lei, nem ato de soberania, e que por conseguinte seria ilegítimo" (ROUSSEAU, 2007, p. 90). Na lógica do pacto social, o contrato tácito estabelecido entre as pessoas institui a unidade política soberana, e não é juridicamente possível que o exercício da soberania conduza a sua própria anulação, por meio da atribuição definitiva de poder a um determinada estrutura de governo.

A teoria de Rousseau é incompatível com o próprio constitucionalismo, que prega a possibilidade justamente da fixação de uma forma de governo que passa a não ser mais modificável por qualquer expressão direta da vontade geral. Além disso, essa teoria não deixa espaço para um dos pilares do direito moderno: a celebração de contratos mercantis entre o povo e pessoas privadas. Tal contrato não pode ser interpretado como um ato de soberania, visto que ambos os contratantes precisam estar submetidos à mesma lei para que o contrato possa viger. Bodin já havia explorado extensamente as aporias ligadas à possibilidade do estabelecimento de contratos entre o soberano e particulares, visto que rompe a lógica do direito civil o fato de o soberano ser ao mesmo tempo legibus solutus e submetido às regras contratuais. Nessa medida, ou consideramos que tais ajustes não podem ser considerados contratos que geram obrigações, ou consideramos que o corpo político pode despir-se de sua soberania para celebrar, em pé de igualdade com particulares, contratos que submetam o soberano a uma norma jurídica de validade heterônoma.

Esse deslocamento gera uma situação peculiar, em que a validade das relações mercantis que envolvem o próprio Estado envolve a afirmação de uma autonomia do direito mercantil, excluindo esse campo da interferência legisladora do Estado e da teoria política que o sustenta. A lei mercantil, baseada nos costumes, deve ser protegida da interferência estatal, para que o próprio Estado possa se beneficiar das possibilidades de acumulação de capital e dos sistema de crédito envolvido no mercado financeiro. Em outras palavras, a estabilidade política decorrente da centralização do poder político nos Estados modernos permitiu o estabelecimento de um sistema financeiro que os próprios Estados somente poderiam utilizar se fossem instituídas restrições a sua própria soberania, o que nos conduz ao espinhoso problema dos mecanismos modernos de constituição de uma soberania popular limitada. 


\subsection{A limitação da soberania no constitucionalismo democrático}

No discurso dos mais destacados autores da teoria da soberania concebida na Europa entre os séculos XVI e XVIII, era evidente o apelo a uma teoria geral do Estado, que justificasse a imposição de um poder absoluto concentrado nas mãos de uma autoridade central. A concepção de uma teoria assim conformada justificava-se, em grande medida, por certo discurso constitutivo da história, que, como escreve Michel Foucault, "fizera surgir o grande perigo; o grande perigo de que fiquemos presos numa guerra infindável; o grande perigo de que todas as nossas relações, sejam elas quais forem, sejam sempre da ordem da dominação" (FOUCAULT, 1999, p. 257). Desse perigo é que se gestou um Estado como detentor exclusivo do aparato militar.

O receio da guerra eterna, cristalizado na modernidade pela racionalidade histórica já referida, levou a uma justificação política da existência do Estado unitário, operante por meio de certa razão administrativa autônoma, que pode ser assim definida:

O que caracterizava essa nova racionalidade governamental chamada razão de Estado, que se
havia constituído grosso modo no decorrer do século XVI, é que nela o Estado era definido e
recortado como uma realidade ao mesmo tempo específica e autônoma, ou ao menos
relativamente autônoma. Ou seja, o governo do Estado deve, é claro, respeitar certo número de
princípios e regras que excedem ou dominam o Estado e são exteriores em relação ao Estado e
são exteriores em relação ao Estado. O governante do Estado deve respeitar as leis divinas,
morais, naturais, leis que não são homogêneas nem intrínsecas ao Estado. Mas, embora
respeitando essas leis, o que o governante tem de fazer é bem diferente de assegurar a salvação
dos seus súditos no outro mundo, enquanto na Idade Média vocês veem o soberano ser
correntemente definido como alguém que deve ajudar seus súditos a se salvar no outro mundo.
Doravante, o governante do Estado não precisa mais se preocupar com a salvação dos seus súditos
no outro mundo, pelo menos não de maneira direta. (...) Em outras palavras, o Estado não é nem
uma casa, nem uma igreja, nem um império. O Estado é uma realidade específica e descontínua.
O Estado só existe para si mesmo e em relação a si mesmo, qualquer que seja o sistema de
obediência que ele deve a outros sistemas como a natureza ou como Deus. (FOUCAULT, 2008,
p. 7)

Nesse contexto, parecia bastante adequada uma teoria da soberania que encontrasse limites unicamente naquilo que limitava a atuação estatal: o direito divino e/ou o direito natural. E, ainda que se considere uma mitigação da razão de Estado a emergência da soberania popular nos moldes de Rousseau ${ }^{24}$, é certo que seu atributo central - a soberania - estava lá preservada. Aliás, justamente por ser soberana é que a vontade geral não poderia ser representada e tampouco

\footnotetext{
${ }^{24} \mathrm{E}$, em certa medida, essa mitigação é confirmada pela afirmação de Carl Schmitt a respeito da construção conceitual de Rousseau: "Em Rousseau, a volonté genérale é idêntica à vontade do soberano; mas, simultaneamente, o conceito do aspecto geral recebe, também em seu sujeito, uma determinação quantitativa, ou seja, o povo torna-se soberano. Com isso, perde-se o elemento decisionista e personalista do conceito de soberania vigente até então. A vontade do povo é sempre boa, le peuple est toujours vertueux" (SCHMITT, 2006, p. 45).
} 
dividida. Numa teoria como a de Hobbes ou a de Rousseau, o poder é um só, ou deixa de ser soberano. "Ou a vontade é geral, ou não; ou é a do corpo do povo, ou só de uma parte dele" (ROUSSEAU, 2007, p. 37).

Como afirma Alexandre Araújo Costa, "enquanto a soberania continuou a ser compreendida como um poder absoluto, ela não conduziu a paradoxos" (COSTA, 2011, p. 203). Isso apenas ocorreu a partir da emergência de elementos conceituais que promoveram a ressignificação do Estado soberano, que agora se transmuta na forma de governo regulador. Se, sob uma teoria forte da soberania, esta é compreendida como a possibilidade de disposição de leis que abrangessem todos os súditos, a - digamos assim - teoria fraca (em que a soberania não é mais que uma expressão do governo das coisas) trata de promover configurações institucionais que conduzam a uma melhor disposição dos elementos submetidos à autoridade do governante.

Ao contrário, aqui não se trata de impor uma lei aos homens, trata-se de dispor das coisas, isto é, de utilizar táticas, muito mais que leis, ou utilizar ao máximo as leis como táticas; agir de modo que, por um certo número de meios, esta ou aquela finalidade possa ser alcançadas. Creio que temos aqui uma ruptura importante: enquanto a finalidade da soberania está em si mesma e enquanto ela tira seus instrumentos de si mesma sob a forma da lei, a finalidade do governo está nas coisas que ele dirige; ela deve ser buscada na perfeição, na maximização ou na intensificação dos processos que ele dirige, e os instrumentos do governo, em vez de serem leis, vão ser diversas táticas. Regressão, por conseguinte, da lei; ou antes, na perspectiva do que deve ser o governo, a lei não é certamente o instrumento maior. (FOUCAULT, 2008b, p. 132)

Essa aproximação entre Estado e governo se deve ao movimento crescente de desconfiança voltada à razão de Estado moderna, aquela racionalidade administrativa autorreferente cuja missão principal era promover a unificação das forças militares para o resguardo de uma constante ameaça de guerra. Como que se reconhecendo a ameaça que surge de um monopólio tal da força, os aparatos de poder da modernidade trataram de instituir um poder central não mais dotado de autoridade, mas, antes de tudo, de uma normatividade reguladora.

É assim que, de modo fragmentário e não linear, vai-se instituindo um princípio de governamentalidade, significante da emergência de certa arte de governar, cuja implicação mais imediata foi a instauração de limitações ao próprio governo. Limitações estas decorrentes não imediatamente do exercício soberano do poder absoluto de um rei, de assembleias ou de populações em geral, mas antes de regulações sociais que impõem a desconfiança de todo governo que viole as fronteiras de esquemas de raciocínio bem delimitados.

Em primeiro lugar, essa regulação será uma regulação, uma limitação de fato. De fato: isto é, não será uma limitação de direito, ainda que o direito se ache na obrigação, um dia ou outro, de transcrevê-la em forma de regras a não serem transgredidas. Em todo caso, dizer que é uma limitação de fato quer dizer que, se o governo vier a atropelar essa limitação, a violar essas fronteiras que lhe são postas, não será ilegítimo por isso, não terá de certo modo abandonado sua 
essência, não se verá destituído de dos seus direitos fundamentais. Dizer que há uma limitação de fato da prática governamental quererá dizer que o governo que desconhecer essa limitação será simplesmente um governo, mais uma vez não ilegítimo, não usurpador, mas um governo inábil, um governo inadequado, um governo que não faz o que convém. (FOUCAULT, 2008a, p. 15)

E assim, pelas limitações de fato postas ao poder de quem governa ${ }^{25}$, é que se inaugura uma série de práticas sociais no Ocidente, as quais servirão de base para a instituição de saberes, de verdades sociais que ora se expressam pela imposição de macropoderes, estatais ou não, que surgem em razão da viabilidade que lhes é permitida pela microfísica das relações sociais, ora se expressam por uma gestão econômica das populações a eles submetidas. A isto é que, na obra de Michel Foucault, denomina-se governamentalidade.

Por esta palavra, "governamentalidade", entendo o conjunto constituído pelas instituições, os procedimentos, análises e reflexões, os cálculos e as táticas que permitem exercer essa forma bem específica, embora muito complexa, de poder que tem por alvo principal a população, por principal forma de saber a economia política e por instrumento técnico essencial os dispositivos de segurança. Em segundo lugar, por "governamentalidade" entendo a tendência, a linha de força que, em todo o Ocidente, não parou de conduzir, e desde há muito, para a preeminência desse tipo de poder que podemos chamar de "governo" sobre todos os outros - soberania, disciplina e que trouxe, por um lado, o desenvolvimento de toda uma série de aparelhos específicos de governo [e, por outro lado], o desenvolvimento de toda uma série de saberes. Enfim, por "governamentalidade", creio que se deveria entender o processo, ou antes, o resultado do processo pelo qual o Estado de justiça da Idade Média, que nos séculos XV e XVI se tornou o Estado administrativo, viu-se pouco a pouco "governamentalizado". (FOUCAULT, 2008b, p. 143-144)

É preciso dizer, nesse sentido, que, nas práticas governamentais, as razões de funcionamento da política, os seus esquemas de atingimento dos objetivos que lhe são postos se buscam no interior mesmo dessas práticas. É dizer: o princípio básico da regulação social que se segue às instituições de governo encontra-se dentro dessas instituições, e não mais no direito natural ou divino que outrora deu conformação ao todo comunitário da política moderna.

O direito que emerge nesse contexto é antes uma consequência, um subproduto, que a fundação social da governamentalidade. No direito, nota-se um movimento que passa a ser cristalinamente contraditório: ao tempo em que se lhe impõem as limitações de fato de uma arte de governar, ele passa a se esforçar por declarar sua autonomia científica e procedimental. No entanto,

\footnotetext{
25 "Limites de fato que podem vir da história, que podem vir da tradição, que podem vir de um estado de coisas historicamente determinado, mas também podem ser e também devem ser determinados como os limites de certo modo desejáveis, os limites adequados a serem estabelecidos justamente em função dos objetivos da governamentalidade, dos objetivos com que ela lida, dos recursos do país, sua população, sua economia, etc. - em suma, a análise do governo, da sua prática dos seus limites de fato, dos seus limites desejáveis” (FOUCAULT, 2008a, p. 55).
} 
os elementos conformadores dessa pretendida autonomia são antes os indícios necessários da expressão de certa governamentalidade jurídica.

A expressão principal do novo direito emergente é o constitucionalismo liberal moderno, cujas características elementares consistem na supremacia constitucional e na separação dos poderes sempre limitados do Estado (ou do governo). Em uma frase, retirada da histórica Declaração de Direitos do Homem e do Cidadão, de 1789, a partir de então, "a sociedade em que não esteja assegurada a garantia dos direitos nem estabelecida a separação dos poderes não tem Constituição". Ambos os elementos operam de modo a estipular as balizas em que pode se locomover as leis soberanas. É dizer: ambas operam de modo a desnaturar, por completo, um atributo indispensável da soberania: seu caráter absoluto. Na verdade, o único momento em que, no constitucionalismo democrático, a soberania continuou soberana foi relegado ao mítico momento fundante das comunidades políticas constitucionais - aquele em que se expressa o poder constituinte.

A categoria foi definida, primeiramente, pelo abade francês Emmanuel Sieyès, para quem a vontade primordial da nação é expressa na lei que define, de forma ilimitada, a forma política da sua comunidade:

Em cada parte, a Constituição não é obra do poder constituído, mas do poder constituinte. Nenhuma espécie de poder delegado pode mudar nada nas condições de sua delegação. É neste sentido que estabelecem a legislatura, são fundadas pela vontade nacional antes de qualquer constituição; formam seu primeiro grau. As segundas devem ser estabelecidas por uma vontade representativa especial. Desse modo, todas as partes do governo dependem em última análise da nação. (SIEYÈS, 2001, p. 49)

A natureza especial desse ato fundante faz com que se alcance uma concepção segundo a qual, na modernidade, "o poder constituinte não tem sido considerado apenas a fonte onipotente e expansiva que produz as normas constitucionais de todos os ordenamentos jurídicos, mas também o sujeito dessa produção, uma atividade igualmente onipotente e expansiva" (NEGRI, 2002, p. 7). O poder constituinte é a expressão da nação ou do povo, assim como constitui essa nação ou esse povo. No entanto, uma vez constituído, esse povo, em virtude de uma regra por si instituída, deixa de deter a onipotência fundante e passa a agir dentro de determinados limites de um assim constituído Estado de Direito. O paradoxo presente na tese de Sieyès, cujas repercussões remanescem na teoria constitucional, é assim bem sintetizado:

Com isso, Sieyès abriu a caixa de Pandora constitucionalista: desejamos um governo limitado, mas fundamentamos essa limitação em uma soberania nacional ilimitada. Portanto, nenhuma nação "Pode impor deveres a si mesma, nenhuma constituição pode limitar a força criativa do soberano. A soberania não é o poder de destituir o tirano, mas o poder de se autorregular. Assim, 
quem fala em nome da nação tem um poder absoluto: o poder constituinte. Mas quem pode falar em nome da nação? A resposta de Sieyès foi: uma assembleia escolhida pelo povo, na qual deve ser respeitado o direito de igualdade, de tal forma que a representação se dá por cabeça e não por ordem. Aqui vem o golpe de mestre: o poder de definir a constituição dos Estados Gerais não pode repetir a organização dos estamentos feudais, mas deve respeitar a igualdade moderna em uma eleição voltada a selecionar representantes extraordinários que exercerão a plenitude do poder constituinte. Mas quem poderia convocar tais eleições? Quem poderia definir os critérios pelos quais seriam eleitos os representantes? Aqui a lógica de Sieyès foi sobrepujada pelo seu engajamento, e ele respondeu a essa questão com outra pergunta: "quando a salvação da pátria é necessária para todos os cidadãos, vai-se perder tempo perguntando-se quem tem o direito de convocar?" (1994: 102). Até esse ponto, Sieyès seguia rigorosamente as regras do discurso jurídico: todo poder tem um titular, todo governo é limitado, o soberano atribui poderes ao governo por meio de uma relação de representação e ele pode alterar a qualquer momento esses poderes. Aqui ele rompeu o argumento porque a lógica jurídica seria reconduzida aos seus paradoxos: quem tem o direito de estabelecer os modos pelos quais o soberano se manifestará? (COSTA, 2011, p. 207-208)

Se da experiência francesa veio a tese de um poder fundante que limita a si próprio, as noções de estabilidade da fundação e de equilíbrio entre poderes sociais advêm principalmente da construção política dos Estados Unidos da América. Esses elementos indispensáveis ao rule of law se conformaram a partir de quatro expressões concretas: constituição escrita, possibilidade de adjudicação constitucional, retórica individualista baseada em direitos negativos e profissionais do direito como "engenheiros sociais" ativos em um sistema altamente decentralizado organizado com o intuito de proteger os direitos de propriedade (MATTEI; NADER, 2008).

Tais ideias são comumente apresentadas, em bancos acadêmicos ou em manuais de direito constitucional, como emergentes de um completo vazio das teorias jurídicas do século XVIII. No entanto, sua adequada compreensão exige a identificação dos elementos de fato que impunham os limites da governança jurídica naquele momento.

Inicialmente, é imprescindível recordar que, se o Estado moderno foi constituído para que detivesse o uso exclusivo da instituição militar, como uma prevenção à situação de guerra eterna, também o seu esvaziamento de poder teve elementos bélicos bem definidos. E eles estão de todo relacionados com a emergência dos imperialismos no século XVIII. Desde o princípio, o rule of law buscou engendrar mecanismos de legitimação para toda sorte de etnocídio. Foram as regras do Estado de direito, por exemplo, que já na chegada de europeus à América do Norte deram suporte ao diagnóstico de que "a descoberta, por exploradores europeus, de terras nas Américas, deu à nação descobridora - e aos Estados Unidos como sucessores - absolutos títulos legais e de propriedade sobre o solo americano, reduzindo as tribos indígenas a meras possuidoras" (WILKINS, 1997). Isso, em que pese os próprios colonos ingleses assinassem acordos com os indígenas como se estes constituíssem nações soberanas, até o século XVII (WILKINS, 2007). 
Como indicam Laura Nader e Ugo Mattei, “a validação da apropriação já era inerente à filosofia de John Locke, nos Dois tratados sobre o governo civil”' (MATTEI; NADER, 2008, p. 67). Rapidamente, abandou-se o tratamento dos nativos como povos de nações autônomas e, na $5^{\text {a }}$ Convenção de Virgínia, em 1776, o povo da famosa declaração "we, the people” já era detentor exclusivo dos direitos de propriedade de todo o território dos Estados Unidos. E tamanhos eram seus direitos que se permitiram, até mesmo, a escravização com respaldo constitucional, após 1787. O sistema de propriedade privada com legitimação constitucional nasceu conjuntamente com o ápice do sistema escravista colonial, quando, superadas as diferenças entre os distintos estados confederados, a igualdade entre colonos se converteu na cristalização da segregação racial ${ }^{26}$.

A situação que se tem, então, é uma articulação de três distintos elementos que caracterizam a vertente hegemônica da teoria política moderna: liberalismo, constitucionalismo e democracia. Se, de um lado, é verdade que eles nem sempre estiveram juntos, também é verdade que souberam aproveitar - ainda que parcialmente -, um do outro, fundamentos de legitimação que levassem à consolidação de determinadas formas de relações de poder social. As relações entre esses diversos entes somente podem ser compreendidas a partir de uma analítica das conformações sociais então verificadas. Tais relações passam, pouco a pouco, a serem dominadas pela esfera dos interesses, os quais se mostram sob a forma das crescentes trocas de mercado, de um lado, e da ideia de utilidade dos governos, de outro.

A razão governamental, em sua forma moderna, na forma que se estabelece no início do século XVIII, essa razão governamental que tem por característica fundamental a busca do seu princípio de autolimitação, é uma razão que funciona com base no interesse. Mas esse interesse já não é, evidentemente, o do Estado inteiramente referido a si mesmo e que visa tão-somente seu crescimento, sua riqueza, sua população, sua força, como era o caso na razão de Estado. Agora, o interesse a cujo princípio a razão governamental deve obedecer são interesses, é um jogo complexo entre os interesses individuais e coletivos, a utilidade social e o benefício econômico, entre o equilíbrio do mercado e o regime do poder público, é um jogo complexo entre direitos fundamentais e independência dos governados. O governo, em todo caso o governo nessa nova razão governamental, é algo que manipula interesses. (FOUCAULT, 2008a, p. 61)

\footnotetext{
26 "A transição da delimitação espacial para a delimitação racial da comunidade dos livres tornou, daí em diante, impossível reprimir a realidade da escravidão. Não havia, então, alternativa à condenação dessa instituição, que não a sua explícita defesa ou celebração. Como o conflito dividindo as duas seções da União emergiu mais claramente, os ideólogos do Sul zombaram, de modo ainda mais provocativo, dos circunlóquios e das interdições linguísticas que facilitaram o compromisso de Filadélfia em 1787. 'A escravidão negra', declarou John Randolph, era uma realidade que 'a Constituição tentou, em vão, ocultar, deixando de usar este termo'. Com a enunciação desse tabu, a legitimação da escravidão perdeu sua timidez que anteriormente a caracterizava, assumindo um tom provocador. Depois de ter sido um mal necessário, a escravidão se tornou (...) um 'bem positivo'. Não fazia sentido tentar reprimi-la como algo a provocar vergonha; na realidade, ela era a base da civilização" (LOSURDO, 2014, p. 56).
} 
Se, sob o regime forte da soberania, o poder soberano se exerce diretamente sobre as coisas sujeitas à sua esfera de decisão, sob o constitucionalismo liberal, determinados interesses passam a mediar as relações entre o governo e aquelas mesmas coisas. Nesse novo momento da história política europeia, ao governo só é dado intervir se houver algum interesse - tornado socialmente relevante a partir da trama de relações sociais de poder - a tutelar. Essa é a medida da utilidade, que passa a ser o parâmetro da atribuição de tarefas ao governante, não mais soberano em seu poder de decisão. O governo, dessa maneira, passa a se exercer sobre o que Foucault denomina uma "república fenomenal dos interesses" (FOUCAULT, 2008a, p. 63-64), na qual está em jogo saber o valor das ações desse governo no interior de uma sociedade baseada em sistemas de troca sob a configuração propriamente capitalista-liberal.

Tal formatação, aliás, era bastante útil ao momento vivenciado pelas potências econômicas europeias no final do século XVIII. É, afinal, nesse contexto que se desenvolve a ideia de um equilíbrio europeu, o qual estava diretamente relacionado aos interesses econômicos mercantis daquele momento. A exploração colonial, como desenvolvida desde o século XV, embora tenha expandido as fronteiras do capitalismo, era ainda sujeita à autoridade dos poderes soberanos, um ansiando superar o outro em conquistas militares e expansão territorial. Não raramente, a situação conflituosa entre os países europeus levava a significativas perdas comerciais, em virtude da sucessão de monopólios que se instaurava. A partir desse diagnóstico, a ainda incipiente teoria econômica liberal acabou por fornecer uma lição aos governos europeus: se a liberdade de mercado poderia funcionar como um modo de atingir o preço dito justo, que levaria a um enriquecimento da coletividade, também os países europeus poderiam, por meio do estabelecimento de mecanismos que evitassem que um prevalecesse demasiadamente sobre o outro, encontrar um balanço de poder que conduza ao progresso econômico (FOUCAULT, 2008a). Esse novo balanço, por outro lado, favoreceria as trocas comerciais, deixando os mercados livres de certas externalidades decorrentes do uso excessivo da máquina de guerra. Outro não é o manto com que se veste Kant ao enunciar seu projeto de paz perpétua:

Assim como a natureza separa sabiamente os povos, que a vontade de cada Estado, e isto mesmo segundo fundamentos do direito internacional, bem gostaria de reunir sob si por astúcia ou força, assim reúne ela também, de outro lado, mediante o proveito pessoal recíproco, os povos, o que o conceito de direito cosmopolita não teria assegurado contra emprego de força e guerra. É o espírito comercial, que não pode subsistir juntamente com a guerra e que mais cedo ou mais tarde se apodera de cada povo. Porque então entre todas as potência (meios) subordinadas à potência do Estado, a potência do dinheiro sendo bem possível a de maior confiança, os Estados veem-se assim (certamente não por móbiles da moralidade) forçados a promover a nobre paz e, seja onde for que no mundo a guerra ameace de eclodir, a afastá-la por mediações, como se estivessem em 
uma aliança estável, pois grandes uniões para a guerra podem, segundo a natureza da coisa, somente muito raramente acontecer e ainda mais raramente ter êxito. (KANT, 2008, p. 53-54)

É esse equilíbrio europeu, viabilizado por meio da adoção de mecanismos institucionais mais ou menos semelhantes no interior dos distintos países, que permitirá pensar o resto do mundo como o objeto dos interesses de mercado. A lógica dos direitos fundamentais universais - e em especial a lógica do direito de propriedade - passa a substituir, ao menos no ideário de justificação dos poderes sociais, o mecanismo simplório da vontade do soberano. O direito de propriedade sempre pressupõe um medium - a coisa não é acessível diretamente pelo exercício de uma vontade juridicamente respaldada, depende-se sempre da força do dinheiro para que exista o direito. E, nessa nova lógica, a posse das novas terras, a expansão para novos mercados, não se justifica mais unicamente pela tese da defesa do melhor interesse do príncipe - a otimização das riquezas como princípio natural a ser perseguido pelos governos é que viabiliza a emergência de novos poderes imperiais. É assim que se inicia uma nova forma de gestão sobre o mundo, “um novo tipo de cálculo planetário na prática governamental europeia" (FOUCAULT, 2008a, p. 77), em que importam antes os mecanismos naturais de adequação e acomodação de mercados que as virtudes autônomas de um direito de liberdade.

Com isso, quer-se dizer: em que pese todo o esforço das codificações ou de certo positivismo científico então nascente, o que o século XVIII e o século XIX trouxeram, em termos jurídicos, foi a percepção do direito como um discurso de afirmação de algo tido por natural - a busca de um quadro institucional que viabilizasse a maior eficiência econômica dos mercados autônomos a partir dos equilíbrios forjados nas normatividades econômicas clássicas.

Essa governamentalidade, articulada por intermédio de categorias jurídicas que deslocam ou difundem o poder soberano - separação dos poderes e adjudicação constitucional são alguns exemplos - somente pode funcionar em um ambiente de determinadas liberdades, ainda que, para garanti-las, seja necessário ativar controles disciplinares específicos.

Com isso, embora esse liberalismo não seja tanto o imperativo da liberdade, mas a gestão e a organização das condições graças às quais podemos ser livres, vocês veem que se instaura, no cerne dessa prática liberal, uma relação problemática, sempre diferente, sempre móvel, entre a produção da liberdade e aquilo que, produzindo-a, pode vir a limitá-la e a destruí-la. O liberalismo (...), esse liberalismo que podemos caracterizar como a nova arte de governar formada no século XVIII, implica em seu cerne uma relação de produção/destruição [com a] liberdade. É necessário, de um lado, produzir a liberdade, mas esse gesto mesmo implica que, de outro lado, se estabeleçam limitações, controles, coerções, obrigações apoiadas em ameaças. (FOUCAULT, 2008a, p. 87) 
Nenhum jogo seria mais propício a essa alternância contínua entre liberdade e repressão que o jogo articulado pelo constitucionalismo. Funcionando como aparelho repressor da arena política, é a petrificação constitucional, nas suas bem definidas estruturas com viés de eternidade, que impede a ampla discricionariedade política, que castra o uso - por assim dizer - abusivo das liberdades em detrimento dos interesses que articulam a projeção dessas estruturas normativas. O natural - agora ditado por meia dúzia de regras econômicas - mantém-se, dessa forma, como o único limite do poder político - este, não mais ditado pela vontade absoluta e perpétua de um soberano, mas pelas expressões individuais das liberdades civilmente garantidas e dos equilíbrios de mercado expressos nos preços justos das trocas sociais.

O liberalismo, afinal, trouxe ao constitucionalismo a noção de que o poder do governo deve experimentar limites estritos. Se coube ao constitucionalismo desenvolver o operacional conceito de poder constituinte para legitimar a eternização de suas formas e também de certa substância constitucional, é o liberalismo que lhe impõe o encerramento temporal e a limitação espacial do poder constituinte. "O poder constituinte é absorvido pela máquina da representação" (NEGRI, 2002, p. 11), impedindo o território político de encontrar plena expansão. A expressão primeira disso pôde ser verificada, como já referido, no tratamento dado pelas potências constitucionais e liberais a certas conformações étnicas diretamente atingidas pela sanha imperial então instalada. Nisso, é particularmente reveladora a experiência das colônias britânicas na América:

Uma vez que o campo da hagiografia tenha sido evacuado, a reconstrução da história do
liberalismo é mais bem contada se iniciarmos com o slogan adotado pelos colonos rebeldes
americanos: "Nós não seremos os seus negros!". De um lado, a rebelião se iniciou demandando
igualdade; mas, por outro lado, ela reafirmou a desigualdade e até mesmo a acentuou. As duas
demandas estavam irremediavelmente ligadas: precisamente porque elas estabeleciam uma
superioridade assinalada sobre os negros e indígenas, os colonos se sentiam completamente iguais
aos nobres e proprietários que residiam em Londres, e demandavam que essa igualdade fosse
reconhecida e consagrada em todos os níveis. A dialética que brotou na Revolução Gloriosa não
foi muito diferente. O que se viu foi um expoente do protoliberalismo inglês demandando, em
face da interferência do poder monárquico, a fruição pacífica de suas próprias posses e de seus
próprios servos. Longe de questionar isso, a "verdadeira liberdade" consagrou as relações de
servidão então existentes (e, nas colônias, a escravidão) como pertencentes à esfera privada
inviolável. A igualdade que os proprietários demandavam perante o soberano, que agora não era
mais que um primus inter pares, seguia passo a passo com a reificação dos servos, que tendiam
a ser relacionados a outros objetos de posse. É por isso que o liberalismo e a escravidão racial
pautada pelas relações de posse [chattel slavery] emergiram juntos, como gêmeos em um
nascimento. (LOSURDO, 2014, p. $301-302$, tradução livre)

Não é difícil perceber que, em tal contexto, aparecem com alguma facilidade certas fraturas característica da modernidade, expressas por meio de pares conceituais antagônicos, mas 
inevitavelmente complementares: direito público/direito privado; esfera pública/economia doméstica; Estado/sociedade civil. Todas essas relações de antagonismo e, ao mesmo tempo, de complementação, estavam bem traçadas na formulação constitucionalista. Elas garantiam que o poder soberano deixasse de intervir nas microssoberanias do mercado, em que os proprietários ditam as regras do equilíbrio natural voltado ao estabelecimento da justiça dos preços. Contudo, ao mesmo tempo, impunham a força do império contra os interesses que, numericamente maiores ou não, pudessem agir contrariamente a essas liberdades certamente seletivas, mas cuja seletividade era vista como indispensável para os fins objetivados pelos teóricos liberais.

\subsection{A nova governança - razão técnica e o vazio constitucional da economia política contemporânea}

A articulação crescente entre o constitucionalismo e o liberalismo, pautada pela tese segundo a qual sempre se governa demais, acabou por levar a um enfraquecimento contínuo da tese da soberania ilimitada na teoria jurídica hegemônica. Deve parecer evidente, a essa altura, que o que se pretende assim dizer é que o liberalismo inaugurou um novo regime de verdade, o que implica dizer que se construíram diversas práticas sociais capazes de "engendrar domínios de saber que não somente fazem aparecer novos objetos, novos conceitos, novas técnicas, mas também fazem nascer formas totalmente novas de sujeitos e de sujeitos de conhecimento" (FOUCAULT, 2008c, p. 8).

No processo de subjetivação decorrente da imposição de certa hegemonia liberal, foi indispensável a concessão de um atributo de racionalidade ao discurso em torno da legitimação dos princípios morais caros à nova vertente predominante da filosofia política. Assim é que, a todo tempo, busca-se obter o convencimento dos indivíduos a respeito do modo como as formas emergentes de conceber a sociedade civil teriam um embasamento científico bem demonstrado. Não por acaso, esses modos de compreensão de áreas como a economia e o direito se desenvolvem de maneira conjunta com a prevalência, na filosofia, do que passou à história como o período do Esclarecimento, a implicar uma busca contínua pela emancipação humana por meio da substituição das explicações míticas do mundo pelo raciocínio científico voltado a fins específicos (ADORNO; HORKHEIMER, 1985). 
Tratava-se de uma tentativa de romper com a metafísica clássica, impondo-se o inexorável progresso da ciência como um novo modo de acesso aos fundamentos da matéria. A técnica - essa técnica moderna dotada de um método científico de apreensão dos objetos da natureza - passa a ser o vetor de desenvolvimento de um modo específico de produção das verdades, de modo que a própria filosofia, em sua tarefa especulativa, passa a ter seu papel secundarizado em nome do "triunfo das organizações programáveis dum modo científico-técnico e da ordenação social conforme a esse modelo" (NEVES, 2003, p. 10). Uma dimensão pragmática do conhecimento passa a ascender, em relevância e autoridade, em detrimento das pretensões de explicação mítica da fundação da autoridade. No entanto, como bem ilustra Castanheira Neves ao expor a tese kantiana da superação da metafísica,

a metafísica superada por Kant foi tão-só a metafísica tradicional ("o conceito tradicional da
metafísica": "metaphysica est sciencia prima cognitionis humanae principia continens"), o que
por isso mesmo não exclui que o próprio Kant tivesse reconstruído, decerto com outro modo e
com outro sentido, a filosofia como o "juiz supremo", posto que agora chamado a explicitar as
condições transcendentais da possibilidade e validade do conhecimento em geral, o conhecimento
do próprio conhecimento, e através desse transcendentalismo convocado o problema do
fundamento e assim a filosofia de novo à universal instância fundamentante, embora sob a forma
de uma crítica da razão pura. (...) Ou seja, através da "impossibilidade" kantiana não tardou que
a problemática metafísica regressasse, posto que decerto outra. (NEVES, 2003, p. 14)

O monstro da razão, criatura mesma da filosofia esclarecida da modernidade ocidental, terminou por se autonomizar de forma absolutamente fragmentada, levando à construção de métodos em cada seara do entendimento humano e reservando-se à filosofia o papel de elemento de legitimação dessa nova forma de raciocínio. É nesse contexto que campos como o direito e a economia passam a reivindicar sua forma autônoma de expressão, a carregar em comum, basicamente, o método científico de lidar com os problemas postos a cada uma dessas áreas.

Se, no direito, esse fenômeno se expressa sobretudo pela emergência de um sistema de pensamento pautado pela prevalência do rule of law, na economia, é a busca contínua por eficiência dos mercados que irá pautar o modo de compreensão das matérias de sua competência. Obviamente, em cada um dos campos, as expressões concretas de uma e outra característica marcante irá variar. No entanto, está lá presente, tanto no direito, como na economia, o aparato que é central e ao qual se referem os distintos modos do pensamento hegemônico.

No sistema do rule of law, importa especialmente o modelo de legitimação das normas jurídicas gerais e abstratas. Desde que emitidas por autoridades competentes para tal, essas normas encontram igual dignidade, não cabendo ao cientista do direito apreciar qual das possibilidades de aplicação encontra-se qualitativamente mais respaldada. Nos termos usados por Hans Kelsen: 
Do ponto de vista orientado para o Direito positivo, não há qualquer critério com base no qual uma das possibilidades inscritas na moldura do Direito a aplicar possa ser preferida à outra. Não há absolutamente qualquer método - capaz de ser classificado como Direito positivo - segundo o qual, das várias significações verbais de uma norma, apenas uma possa ser destacada como "correta" - desde que, naturalmente, se trate de várias significações possíveis: possíveis no confronte de todas as outras normas da lei ou da ordem jurídica. (KELSEN, 2006, p. 391)

Esse modo específico de se compreender o direito enquadrava-se naquilo que Martii Koskenniemi indica como um mindset kantiano, assim descrito pelo autor:

No entanto, se as regras do direito não dizem as suas condições de aplicação, então sua virtude
moral (ou seu aspecto político) não pode repousar nas formulações de leis positivas ou naquilo
que elas buscam alcançar na prática, e qualquer fórmula moral, como, por exemplo, a sua
possibilidade de promover a liberdade, dependerá exclusivamente do seu caráter de regras
jurídicas, do seu proprium jurídico. O mérito do direito seria, então, não propriamente aquilo que
ele contém dos contornos de relações sociais ideais adequáveis a cada contexto ou a cada período.
Isso será sempre deixado para a imaginação da auctoritas interpositivo, cujo julgamento na
aplicação do direito se torna a face visível, como direito público, da liberdade. (...) o rule of law,
nessa imagem kantiana, relaciona-se com o modo como o aplicador do direito (administrador,
agente público, advogado) cumpre o papel, de um lado, de julgar no interior do espaço bastante
restrito de compreensões textuais (positivismo) e, de outro lado, de julgar no interior de objetivos
funcionais predeterminados (naturalismo), sem endossar a proposição de que as decisões
emergem de um "nada jurídico" (decisionismo). (KOSKENNIEMI, 2007, p. 11-12)

O rule of law, verdadeiro motor das posições que, de um lado e de outro do espectro político, sempre lhe fazem referência, passa a ter um verdadeiro caráter de dispositivo, no sentido que foi emprestado à palavra por Giorgio Agamben, ancorado em categorias desenvolvidas por Foucault e Hegel. Partindo de uma perspectiva ontológica da política, Agamben identifica o dispositivo como "aquilo que e por meio do qual se realiza uma pura atividade de governo sem nenhum fundamento no ser" (AGAMBEN, 2013, p. 38). Qualitativamente, importa menos um conteúdo específico de uma ou outra lei e torna-se mais relevante o processo de deliberação, aprovação e subsunção de regras específicas a regras gerais.

De algum modo, é possível dizer que esse processo, no interior do direito, levou a processos de despolitização caracterizados pela dessubjetivação mediadora do "eclipse da política, que pressupunha sujeitos e identidades reais (o movimento operário, a burguesia etc.), e o triunfo da oikonomia, isto é, de uma pura atividade de governo que visa somente à sua própria reprodução" (AGAMBEN, 2013, p. 48-49). Importa ao direito referir-se sempre a si mesmo, no interior dos processos geradores de normatividade - geradores, afinal, de verdades jurídicas, as quais somente podem ser encontradas no interior do método da subsunção.

A tese do constitucionalismo realiza esse mindset kantiano e, nesse movimento, deixa evidente o aspecto nitidamente dispositivo da mediação por si promovida. Ao prever as regras de organização da produção normativa, a Constituição reforça a si mesma e reforça também suas 
fundações por intermédio da ideia de poder constituinte. Promove, dessa maneira, uma tentativa de reunificação do poder em torno de um texto específico que tenta insistentemente fazer-se prevalecer pelos seus limites textuais (no caso da leitura positivista) ou pelo seu conteúdo emancipatório - sempre seletivo (na leitura naturalista). É sempre uma tentativa, limitada pela própria incapacidade decorrente do processo de despersonalização do soberano, de reavivar a tese da soberania, mas agora com a roupagem da limitação que o poder confere a si mesmo. Isso faz com que a perspectiva relacional do poder seja velada pelo discurso recorrente da unidade fundante. Nas palavras de Michel Foucault,

A teoria da soberania se confere, no início, uma multiplicidade de poderes que não são poderes no sentido político do termo, mas são capacidades, possibilidades, potências, e (...) ela só pode constituí-los como poderes, no sentido político do termo, com a condição de ter, entrementes, estabelecido, entre as possibilidades e os poderes, um momento de unidade fundamental e fundadora, que é a unidade do poder. (FOUCAULT, 1999, p. 49-50)

Ao mesmo tempo em que no direito se buscava o reforço da técnica da subsunção para a afirmação de sua autonomia, o discurso econômico passou a adotar por base a tese da maximização da eficiência de recursos escassos para impor sua própria normatividade, vindo essa racionalidade a se expandir de tal modo que passou a pautar as políticas públicas de intervenção sobre a organização econômica dos domínios de um Estado, em um fenômeno que tornou cada vez mais frequentes. Especialmente a segunda metade do século XX assistiu à construção de um relevante e inovador discurso a respeito do que seria um bom governo nas sociedades ocidentais. Ao lado de um esforço contínuo de racionalização dos processos estatais, verificou-se uma crescente influência dos enunciados de verdade científica sobre a conformação da ação estatal. Trata-se de uma potencialização da articulação histórica, iniciada no século XVIII e aperfeiçoada no século XIX, entre o iluminismo filosófico e o cientificismo sociológico. Como identificou Hans Peter Dreitzel, em ensaio inaugural sobre a questão do empreendimento científico da ação estatal, "a racionalização da ação sócio-política sempre foi a consequência prática que a sociologia esperava de seus esforços científicos” (DREITZEL, 1975, p. 11). Referida modalidade do agir humano se caracteriza, em primeiro lugar, por uma "vinculação primária da ação sensata [racional] à experiência prática do ambiente imediato de vida, mas também, às normas específicas dos grupos" e, em segundo lugar, pelo "conhecimento claro sobre os objetivos, os meios e os efeitos secundários da ação" (DREITZEL, 1975, p. 14) por parte do ator que a empreende.

Curiosamente, essa nova visão de mundo passou a encontrar lugar no interior dos sistemas de pensamento jurídico, os quais passaram a se sensibilizar pelos conhecimentos provenientes das 
áreas técnicas do conhecimento humano. O direito, nesse sentido, além de conhecer uma autonomia técnica que lhe era própria, tornou-se, ele mesmo, correia de transmissão da tecnificação social a cuja emergência se assistiu desde meados do século XX, e alguns dos fenômenos que recentemente têm chamado a atenção da teoria do direito são indícios do modo a juridicidade incrementou seus parâmetros de racionalidade por meio da incorporação desses novos elementos.

Na virada do milênio, três fenômenos pareceram ofuscar esses desenvolvimentos [do processo
de constitucionalização]: "desformalização", "fragmentação" e "império". Por desformalização,
eu quero dizer o processo por meio do qual o direito recua até o ponto de se tornar unicamente
uma previsão de procedimentos ou um conjunto de diretivas a experts e administradores
[decision-makers], formuladas de modo bastante aberto, com o propósito de se gerenciarem
problemas internacionais por meio de soluções efetivas e "balanceamento de interesses". Por
fragmentação, compreendo a divisão do direito em "regimes" definidos funcionalmente, como
"direito comercial", "direitos humanos", "direito criminal", "direito ambiental", "direito do mar",
até mesmo "direito desportivo", cada um movido por tipos de interesses bastante particulares e
gerenciados pela competência bem definida de experts. Por império, eu quero dizer a emergência
de padrões de coação deliberadamente voltados a fazer avançarem os objetivos de um só ator
dominante, seja por meio do direito ou à margem dele. (KOSKENNIEMI, 2007, p. 13, tradução
livre)

A conjunção dos fenômenos, na concepção de Koskenniemi, faz o autor reconhecer a ascensão de uma nova forma de percepção dos problemas postos em termos de decisões jurídicas - trata-se de um mindset gerencial, construído a partir da percepção de que o direito, em suas formas tradicionais, falhou na "administração dos problemas do mundo globalizado devido ao seu formalismo e à sua rigidez excessivos, bem como devido à sua incapacidade de 'adaptar-se' às novas necessidades regulatórias” (KOSKENNIEMI, 2007, p. 13, tradução livre).

Em virtude desse fato, verifica-se o surgimento de um novo pluralismo jurídico, dessa vez desvinculado das propostas que ainda repousam sob o manto do Estado-nação e submetidas aos ritos da supremacia constitucional. A fonte dessa nova formulação do direito encontra-se propriamente "no 'proto-direito' de redes especializadas, formalmente organizadas e funcionais, que criam uma identidade global, porém estritamente social", de modo que esse novo direito "não se nutre de estoques de tradições, e sim da auto-reprodução contínua de redes globais especializadas, muitas vezes formalmente organizadas e definidas de modo relativamente estreito" (TEUBNER, 2003, p. 14).

Em alguma medida, é a aceleração das repostas requeridas pelos tempos contemporâneos que faz escapar ao direito político tradicional, sempre mediado por procedimentos parlamentares de representação e elaboração normativa. Nos mercados globalizados, a agilidade das operações 
econômicas não pode aguardar as disputas de interesses visto como menores da política democrática.

No contexto específico da União Europeia, o fenômeno é diagnosticado por Hauke Brunkhorst, para quem o mindset gerencial encontrou amplo espaço de difusão em razão do fato de que o momento constitucional dos países europeus no pós-guerra seguiu-se de um "incrementalismo evolucionário medíocre" e de um "processo silencioso, mas contínuo e gradual, de uma integração cada vez mais densa" (BRUNKHORST, 2014, p. 97). Na esteira de uma Zweckrationalität em nível político, a Europa se consolidou institucionalmente mais a partir dos resultados tecnológicos de sua conformação estrutural do que em razão da verificação de uma congregação de vontades políticas (HABERMAS, 2014), o que contribui para evidenciar os termos do processo político em que se viu imersa a modernidade política ocidental.

Nesse processo,

A assunção do mindset gerencial é refletida na transformação dos vocabulários do poder. A
linguagem do direito é substituída por um idioleto dos regimes transnacionais que aplicam os
mais variados tipos de diretrizes, diretivas, padrões de facto e expectativas, de modo a garantir
efeitos otimizados. As regras formais sucumbem à "regulação" amorfa emergente de uma
variedade emergente de fontes e atores. O "governo" se torna "governança" e a linguagem da
"responsabilidade" jurídica é transformada em análises de "compliance". "Disputas" se tornam
"problemas gerenciais" e a questão da legalidade é deslocada para os temas relacionados com a
"legitimidade", instavelmente situada entre a formalidade legal e a justiça política - mas não
redutível a nenhuma delas - e revelada principalmente por meio de um feeling de legitimidade,
um sentimento forte de contentamento que não precisa de maior justificação. (KOSKENNIEMI,
2007, p. 13-14)

Diante dessa constatação, particularmente no que tange à matéria econômica, verifica-se que a autonomia cognitiva dos sistemas é mitigada por uma interação cada vez mais forte e articulada entre ambos. O direito deixa de representar, para a economia, simplesmente a pesada mão do Estado, a reprimir as liberdades privatísticas, na medida em que o próprio caráter públicodemocrático do direito é desnaturado. Por outro lado, tampouco se pode dizer que o direito pertence, nessa visão de mundo, à ordem da superestrutura. Como diagnostica Foucault em sua exposição sobre o ordoliberalismo alemão, “o jurídico não é concebido, por eles, como estando numa relação de pura e simples expressão ou instrumentalidade em relação à economia" (FOUCAULT, 2008a, p. 225). Isso porque a tese de que a economia é um sistema regulado que deve favorecer determinados fins (seja a eficiência de mercado, seja o favorecimento da concorrência), e não meramente um conjunto de assunções naturalísticas, ganha bastante força no interior do mindset gerencial. 
De todo modo, o econômico não é um processo mecânico ou natural, não é um processo que se possa separar, a não ser por abstração a posteriori, por abstração formalizante. O econômico não pode jamais ser considerado senão como um conjunto de atividades, e quem diz atividades diz necessariamente atividades reguladas. É esse conjunto econômico-jurídico, é esse conjunto de atividades reguladas que Eucken chama - mas aqui numa perspectiva mais fenomenológica que weberiana - de "sistema". O que é o sistema? Pois bem, é um conjunto complexo que compreende processos econômicos cuja análise propriamente econômica decorre, de fato, de uma teoria pura e de uma formalização que pode ser, por exemplo, a formalização dos mecanismos de concorrência, mas esses processo econômicos só existem realmente na história na medida em que uma moldura institucional e regras positivas lhe proporcionaram suas condições de possibilidade. (FOUCAULT, 2008a, p. 226)

Face a esse contexto, não é incomum a percepção de que a política moderna teria verdadeiramente perdido seu lugar de protagonismo, em favor das assunções genéricas de uma economia globalizada, desenvolvida no interior de quadros institucionais bastante restritos, mas profundamente tecnificados, acessível não mais ao público em geral, mas somente a um conjunto restrito de experts.

O que podemos observar hoje em dia, em matéria de globalização, não é a sociedade mundial paulatinamente configurada pela política internacional, mas um processo extremamente contraditório, integralmente fragmentado de globalização, impulsionado pelos sistemas parciais individuais da sociedade em velocidades distintas. Em tais processos, a política não apenas perdeu o seu papel de liderança, mas regrediu nitidamente em comparação com outras áreas parciais da sociedade. Em que pesem toda a internacionalidade da política e todo o direito internacional, a ênfase da política e do direito ainda nos dias de hoje recai no Estado-nação. E mais: fazem-se sentir tendências nítidas, até dramáticas, a uma maior regionalização e localização da política. Na via da globalização, a política foi claramente ultrapassada pelos outros sistemas sociais. Já há muito tempo ela está a caminho das suas global villages respectivamente próprias. E essas global villages se preparam para defender tenazmente a sua autonomia diante das pretensões hegemônicas da política. (TEUBNER, 2003, p. 12)

Perante um tão desalentador quadro da política democrática deliberativa, não demora a aparecer quem levante, desde já, uma forte crítica a essa reformulação dos processos políticos. Jürgen Habermas, por exemplo, após uma forte defesa da formulação de uma constituição europeia como alternativa aos nacionalismos identitários ${ }^{27}$, de modo já desiludido, diagnosticou que “os

\footnotetext{
${ }^{27}$ A forte esperança de Habermas na constitucionalização europeia - sublimando as pretensões imperiais que poderiam decorrer da formação de uma federação plural de Estados nacionais e que de fato se verificaram posteriormente com a crise econômica de 2008 e 2009 - pode ser verificada no seguinte trecho do seu ensaio A Europa precisa de uma Constituição?: "Dessa perspectiva, a autocompreensão ético-política do cidadão de uma coletividade democrática não surge como elemento histórico-cultural primário que possibilita a formação democrática da vontade, mas como grandeza de fluxo em um processo circular que só se põe em movimento por meio de uma institucionalização jurídica de uma comunicação entre cidadãos de um mesmo Estado. Foi exatamente assim que se formaram as identidades nacionais na Europa moderna. E por isso seria de esperar que as instituições políticas que viessem a ser criadas por uma Constituição Europeia tivessem um efeito indutivo. No entanto - enquanto houver vontade política para isso nada depõe a fortiori contra a possibilidade de se criar o contexto comunicacional politicamente necessário em uma Europa que cresce unida (econômica, social e administrativamente) e na qual se dispõe de uma base cultural comum e uma experiência histórica conjunta de bem-sucedida superação do nacionalismo. Na verdade, para que esse contexto de comunicação se estabeleça parece faltar apenas um desencadeamento por via jurídica constitucional" (HABERMAS, 2007, p. 189-190).
} 
espaços realmente determinantes da política europeia são formados nos círculos que decidem sobre policies, de acordo com diagnósticos estritos da crise" (HABERMAS, 2014, p. 13), para então lançar uma renovada aposta na lógica de uma solidariedade mediada pelos procedimentos democráticos de criação de direitos. Em seu entender, "apenas a política de um legislador que é sensível às exigências normativas de uma sociedade civil democrática pode tornar as demandas por solidariedade dos marginalizados ou de seus defensores em direitos sociais" (HABERMAS, 2014, p. 27).

Essa concepção, porém, passa ao largo de uma diferenciação epistemológica suscitada pelos novos problemas emergentes na ordem econômica globalizada. Com a ascensão do neoliberalismo - especialmente aquele de base austríaca e norte-americana de que são expoentes figuras como Friedrich von Hayek e Milton Friedman -, a forma empresarial se difundiu de tal modo que todas as dimensões da vida social nas sociedades capitalistas passaram a ser integradas a partir de um viés empresarial. Os indivíduos, em suas relações com outros indivíduos, com os bens que possuem, com os contratos que assinam, com os seguros em que se investe, com sua aposentadoria, enfim, com todas essas formas características de mercados e vidas altamente financeirizados, passaram a, eles próprios, serem tomados como micro-organizações empresariais $^{28}$.

Não se demora para compreender que essa radicalização da forma empresarial se revela em discursos cotidianos sobre investimentos em "capital humano" ou na substituição contínua de trabalhadores por microempreendedores individuais, sobre os quais se debruça não mais a antiga solidariedade de classe, mas antes a lógica concorrencial do capitalismo global. E mesmo aqueles que se poderiam diagnosticar como vítimas do processo de mercantilização da vida, por assim dizer, passam a reproduzir, em suas relações, a lógica dos poderes sociais disciplinares emergentes. Trata-se de um mecanismo, por excelência, de exercício de poderes difusos, de micropoderes sociais que se reproduzem transversalmente, a partir de distintos centros de comando. Por analogia,

\footnotetext{
28 “Ora, que função tem essa generalização da forma 'empresa'? Por um lado, claro, trata-se de desdobrar o modelo econômico, o modelo oferta e procura, o modelo investimento-custo-lucro, para dele fazer um modelo da existência, uma forma de relação do indivíduo consigo mesmo, com o tempo, com seu círculo, com o futuro, com o grupo, com a família. (...) com esse modelo da empresa, o que se trata de fazer é que o indivíduo (...) já não seja alienado em relação ao seu meio de trabalho, ao tempo da sua vida, ao seu casamento, à sua família, a seu meio natural. Trata-se de reconstituir pontos de ancoragem concretos em torno do indivíduo (...). O retorno à empresa é, ao mesmo tempo, portanto, uma política econômica ou uma política de economização de todo o campo social, de guinada de todo o campo social para a economia" (FOUCAULT, 2008a, p. 332).
} 
poderíamos aqui recordar a lição de Michel Foucault no que tange ao exercício do poder punitivo pela justiça criminal, como um poder que se exerce mais do que se possui:

\begin{abstract}
Ora, o estudo desta microfísica supõe que o poder nela exercido não seja concebido como uma propriedade, mas como uma estratégia, que seus efeitos de dominação não sejam atribuídos a uma "apropriação", mas a disposições, a manobras, a táticas, a técnicas, a funcionamentos; que se desvende nele antes uma rede de relações sempre tensas, sempre em atividade, que um privilégio que se pudesse deter; que lhe seja dado como modelo antes a batalha perpétua que $o$ contrato que faz uma cessão ou a conquista que se apodera de um domínio. Temos em suma que admitir que esse poder se exerce mais que se possui, que não é o "privilégio" adquirido ou conservado da classe dominante, mas o efeito de conjunto de suas posições estratégicas - efeito manifestado e às vezes reconduzido pela posição dos que são dominados. Esse poder, por outro lado, não se aplica pura e simplesmente como uma obrigação ou uma proibição, aos que "não têm"; ele os investe, passa por eles e através deles; apóia-se neles, do mesmo que eles, em sua luta contra esse poder, apoiam-se no ponto em que ele os alcança. (FOUCAULT, 1987, p. 24)
\end{abstract}

É dizer: o enfrentamento de uma forma tão múltipla e plural de expressão de poderes sociais exercido pelas formas econômicas atuais mediante o apelo a uma perspectiva racional unitária da ação política parece, para dizer o mínimo, uma tentativa ingênua e infrutífera de pretender ressuscitar o fundamento perdido do constitucionalismo democrático ${ }^{29}$. Na verdade, parece-nos que seria mais interessante verificar o modo como o constitucionalismo democrático, não tendo perdido por completo sua vocação de mobilizador político, atua também de modo estratégico como um legitimador do mindset gerencial predominante na economia política contemporânea. Isso porque,

Na dinâmica da sociedade capitalista, a natureza do poder e o caráter do direito não são atributos exclusivos de qualquer forma política social, institucional ou jurídica específica, mas resultantes de suas distintas possibilidades de articulação. Interagindo e interseccionando-se de modo permanente ou contínuo, esses espaços tendem a criar complexas, dinâmicas e inéditas relações entre si, resultando assim numa mescla ou numa combinação de várias concepções de legalidade e distintas gerações de normas, algumas mais antigas e outras mais recentes; ou seja, numa mistura desigual de ordens jurídicas com diferentes regras, procedimentos, linguagens, escalas, áreas de competência e mecanismos adjudicatórios. (FARIA, 2004)

Nesse sentido, é importante relembrar que, ao menos no contexto do direito europeu, o mindset gerencial "não apenas desalojou e reprimiu o mindset kantiano da fundação revolucionária, como - em um movimento paradoxal - também o estabilizou e o realizou legalmente, pouco a pouco" (BRUNKHORST, 2014, p. 97). O indício mais forte disso encontra-

\footnotetext{
${ }^{29}$ Nesse particular, parece relevante a recomendação de Michel Foucault, na sua Introdução à vida não fascista: "Libere a ação política de toda a forma de paranoia unitária e totalizante. Faça crescer a ação, o pensamento e os desejos por proliferação, justaposição e disjunção, antes que por submissão e hierarquização piramidal. Libere-se das velhas categorias do Negativo (a lei, o limite, a castração, a falta, a lacuna) que o pensamento ocidental por tanto tempo manteve sagrado enquanto forma de poder e modo de acesso à realidade. Prefira o que é positivo e múltiplo, a diferença à uniformidade, os fluxos às unidades, os agenciamentos móveis aos sistemas, considere que o que é produtivo não é sedentário, mas nômade" (FOUCAULT in DELEUZE; GUATTARI, 1977).
} 
se justamente nas regulações decorrentes da implantação da moeda única. Ao se estabelecer uma união monetária sem que houvesse a correspondente elaboração de um governo político comum, finalizou-se o projeto constitucional e implementou-se "o currículo secreto de uma governamentalidade europeia por meio de uma 'imunização dos mercados contra correções democráticas"” (BRUNKHORST, 2014, p. 101). Por outro lado, as liberdades privadas que precisavam ser exercidas para a garantia dos desenvolvimentos econômicos pretendidos por ordo e neoliberais precisaram recorrer à estrutura de uma cidadania europeia que somente encontrava respaldo nas prerrogativas constitucionais dos sujeitos de direito.

Uma vez mais, o que se tem é uma seletividade dos argumentos constitucionais. Estes somente são mobilizados no sentido de garantir um rol restrito de prerrogativas dos indivíduos, compatíveis com o desenvolvimento da governamentalidade regulatória que não deriva senão de um complexo jurídico-econômico de normalização social. É esse complexo, sempre justificado pelas assunções da razão econômica ou do regramento jurídico sustentado pela estrutura das cortes constitucionais, que viabiliza que não apenas os mercados funcionem sob uma perspectiva de oferta e demanda e de busca por máxima eficiência. A situação presente, fortemente influenciada pelas conformações de poder contemporâneas que se difundem no âmbito das microrrelações cotidianas, termina por implicar uma ampliação da racionalidade do mercado, de modo que seus esquemas analíticos e seus critérios de decisão passam a informar o funcionamento social de campos não propriamente econômicos (FOUCAULT, 2008a, p. 439).

O que se tem, portanto, é uma vez mais a mútua interação entre política, direito e economia hegemônicas. Em que pesem os esforços de distanciamento de certa teoria constitucional-social dos esquemas de análise próprios dos mercados liberais, uma modalidade de ação política pautada por esquemas de gestão pré-definidos não se distancia muito da visão segundo a qual "não podemos explicar a pretensão de validade das normas sem recorrer ao acordo motivado racionalmente ou, no mínimo, à convicção que o consenso sobre uma determinada norma possa efetuar-se com razões" (HABERMAS, 1980, p. 133). Parte-se do pressuposto de compartilhamento linguístico para, então, legitimar-se a tomada de decisões no campo propriamente político, concebendo-se uma vinculação e uma interdependência circular - as quais ganham contornos de inevitabilidade - entre a universalização da filosofia prática e a formulação de enunciados de verdade:

A problemática, que surge com a introdução de um princípio moral, está disposta assim que alguém veja que a expectativa da redenção discursiva das pretensões normativas de validade esteja contida já na estrutura da intersubjetividade e torne especialmente introduzidas as máximas de supérflua universalização. Ao assumirmos um discurso prático, supomos inevitavelmente uma 
situação ideal de discurso que, baseado na força das suas propriedades formais, só permita consenso através de interesses generalizáveis. Uma ética cognitiva linguística não tem necessidade de princípios. Está baseada apenas em normas fundamentais do discurso racional que precisamos sempre pressupor, se usamos de algum modo o discurso (HABERMAS, 1980, p. 139).

Uma tal visão, com amplos reflexos sobre a compreensão das ciências sociais na contemporaneidade, não pode ser percebida de modo distanciado de um contexto histórico mais amplo no qual se insere, e que se estende já há vários séculos da modernidade ocidental, embasado em uma premissa nem sempre aparente que implica que "somos forçados a produzir a verdade pelo poder que exige essa verdade e que necessita dela para funcionar; temos de dizer a verdade, somos coagidos, somos condenados a confessar a verdade ou a encontrá-la" (FOUCAULT, 1999, p. 29).

A gestão, afinal, em sua governamentalidade sistêmica estruturada nas intersecções entre as lógicas internas dos sistemas jurídico e econômico, acaba por não se distanciar de uma teoria da soberania limitada de caráter formal-procedimental, gestada ao longo da modernidade ocidental.

Em primeiro lugar, sua noção de "interesse" ou "objetivo", que presume atores homogêneos com
total conhecimento do seu ambiente e uma estabilidade das preferências análoga à teoria legalista
da vontade, vacila entre uma visão psicológica cega aos condicionamentos sociais da formação
de interesses e uma teoria naturalística (e autoritária) de "interesses objetivos". Em segundo lugar,
a tradução de interesses ou objetivos ("brutos") em preferências políticas é tão indeterminada
quanto a tradução da "vontade" em "regras" na legislação formalista. (...) Em terceiro lugar, a
aplicação de uma política às instâncias individuais da prática dificilmente se dá de maneira
distinta da aplicação de regras. Tal qual as regras, as políticas vêm com exceções ou
contramedidas e são aplicadas em "contextos" que podem ser descritos em um sem-número de
formas. A questão interessante, portanto, não é mais "que política", mas quis judicabit ${ }^{30}$. E em
quartolugar, a busca por compliance pressupõe o completo conhecimento de que compromissos
devem ser seguidos, é dizer, qual seria o padrão comportamental (i.e. "regra"). (...)
Paradoxalmente, o mindset gerencial pressupõe a determinabilidade absoluta das diretivas que
ele utiliza para perseguir os objetivos dos regimes especializados, os quais devem ser não somente
determinados semanticamente, mas também devem formar um todo estável e harmônico,
imediatamente traduzível em uma política [policy] para casos futuros. Isso é mais que
formalismo, é a caricatura da Begriffjurisprudenz ${ }^{31}$ do século XIX. (KOSKENNIEMI, 2007, p.
16)

No regime de verdade posto em discussão quando se trata da articulação entre o pleito de unidade do constitucionalismo e as multiplicidades provenientes de uma governamentalidade tecnocrática, chamam mais atenção as semelhanças e as contiguidades que as pretensas rupturas. Podemos começar a contar a história da verdade que é objeto desse trabalho a partir da percepção de um fato histórico que é o desenvolvimento da teoria da soberania, gestada a partir de uma inegável articulação entre mecanismos jurídicos e políticos que se voltaram, sucessivamente, a: (a)

\footnotetext{
${ }^{30}$ [N.T.] Quem deve julgar?.

${ }^{31}$ [N.T.] Jurisprudência dos conceitos.
} 
fundamentar o poder régio nas monarquias feudais; (b) justificar a edificação das monarquias administrativas; (c) articular as disputas entre o campo político-administrativo e o campo religioso entre os séculos XVI e XVII; e (d) legitimar a construção de democracias parlamentares a partir do século XVIII (FOUCAULT, 1999, p. 42-43). E, mesmo quando ela parece próxima de uma superação, pela multiplicidade das formas de normalização na sociedade contemporânea, é que se revela que, já há bastante tempo, há certa governamentalidade que se articula, a todo instante, com a força (seletiva, não custa lembrar) que pode ser imposta pela via da unidade soberana. 


\section{ANÁLISE DAS DECISÕES JUDICIAIS}

\subsection{A questão da soberania e a divisão entre atos de império e atos de gestão}

O problema da soberania aparece, nas decisões judiciais analisadas, sob distintas - porém congruentes - perspectivas. Merece destaque, inicialmente, a distinção realizada pela Corte de Cassação Italiana, entre atos de império e atos de gestão. Como referido anteriormente, compreendeu-se, naquela ocasião, que a emissão e o lançamento no mercado financeiro de títulos da dívida pública argentina compreendiam atos de gestão. Por outro lado, os atos legislativos emergenciais, por meio dos quais se levou a cabo a moratória daquele país, foi reconhecida como ato de soberania.

Conforme se expôs, a corte italiana assim procedeu porque, de um lado, as leis tratavam de matéria orçamentária - cujo controle encontra limites rígidos mesmo no âmbito do direito interno - e, de outro lado, tinham finalidade de ordem pública, vez que objetivavam manter garantias sociais em um contexto de grave crise econômica. Julgou-se que o que se discutia naquela ocasião eram precisamente os atos emergenciais cuja legitimidade era atacada pelo credor Luca Borri. Para a corte, disso deveria decorrer que o ato argentino gozava de imunidade de jurisdição.

De modo não tão direto, a divisão também transparece na decisão da corte alemã. Ali, decidiu-se que o regime de direito internacional não era aplicável à situação em questão, pois a relação jurídica estabelecida entre a Argentina e seus credores era de direito privado. Já no caso da decisão da Suprema Corte dos Estados Unidos da América, a cisão entre atos de império e atos de gestão não foi imprescindível para a decisão, pois admitiu-se que, ainda que se considere a imunidade decorrente da soberania, ela não implica uma previsão de proibição ou limitação da garantia da execução pelos credores de um Estado devedor que havia renunciado às prerrogativas de soberania no tocante à constituição da dívida.

A divisão entre atos de império e atos de gestão não é uma inovação. Ela se tornou possível a partir do momento que o próprio Estado passou a agir como um importante player de mercado. Conforme se buscou elaborar no Capítulo 1, a análise econômica hegemônica na contemporaneidade, fortemente influenciada pelo neoliberalismo de matriz norte-americana, caracteriza-se por uma generalização ilimitada da forma econômica forjada por essa vertente teórica (FOUCAULT, 2008a). A expansão do comportamento do homo aeconomicus a campos antes não apreendidos pela disciplina econômica acabou por atingir, em grande medida, as próprias 
estruturas de Estado em razão das quais se desenvolveu o liberalismo. Obviamente, isso se deu para que se promovesse o favorecimento de propósitos políticos bem definidos.

Se é verdade que o neoliberalismo deu continuidade à forte desconfiança em relação ao poder soberano dos Estados, é igualmente certo que, sob suas diretrizes, o que restou do Estado passou a se dedicar à tarefa de organizar suas atribuições de modo a que se atingisse a máxima racionalidade de mercado. As estruturas públicas passam, então, a atuar de modo a favorecer o funcionamento eficiente das trocas sociais, em suas mais distintas dimensões. Nesse contexto, ganham corpo reformas administrativas que se voltam a incorporar a estrutura estatal à dinâmica empresarial contemporânea.

Ocorre aí um encaixe entre a emergente estrutura tecnocrática de base racional-moderna, o hegemon econômico neoliberal e as estruturas políticas que determinam o funcionamento da Administração Pública nos Estados ocidentais. Trata-se da concretização daquilo que já havia sido diagnosticado por Max Weber, para quem o Estado racional moderno, apoiado em uma burocracia especializada e em um direito racional, é o "único terreno em que o capitalismo moderno pode prosperar" (WEBER, 1980, p. 158). Analisando as bases romanísticas do Estado racional, Weber deixa claro que a especialização burocrática e a estrutura lógico-formal dos sistemas jurídicos voltam-se, sobretudo, a um "esmagamento" do direito material em prol de um aparato formal calculável, capaz de retirar o monopólio da previsibilidade dos resultados jurídicos das mãos do soberano e distribuí-los aos agentes econômicos capitalistas (WEBER, 1980, p. 160).

Como se extrai desses desenvolvimentos, se o liberalismo buscou, em nível teorético, o desacoplamento entre Estado e regulamentos autônomos dos mercados no interior da sociedade civil, na prática, a manutenção de estruturas institucionalizadas que previssem uma regulação jurídica da intervenção nos domínios econômicos (sobretudo pela via da proteção à propriedade) foi uma das expressões do sucesso da empreitada capitalista. Para os fins deste trabalho, considerase intervenção tanto o agir quanto o não-agir estatal. Isso porque é justamente no exercício dessa seletividade, nessa atuação fragmentária e mediadora do Estado, que repousa a força da coligação entre os interesses em jogo nos mercados capitalistas e o aparato político-institucional, elementos reveladores das relações de poder ora em discussão. No dizer de Daniel Bin:

A intervenção estatal na economia assume assim um caráter de classe, o que nem sempre é perceptível devido ao universalismo formal inscrito, por exemplo na concepção de Estado como promotor de bem-estar. Tal caráter refere-se não à arbitragem tampouco à neutralidade estatais, mas ao exercício do poder de classe por meio do Estado, o qual "medeia relações sociais entre dominantes e dominados" (Therborn, [1978] 2008, p. 169, grifo no original). (BIN, 2010, p. 65) 
Durante o período de ascensão teórico-burocrática do neoliberalismo, verifica-se, para além dos elementos já mencionados, um movimento mais forte de financeirização da economia pública, perfeitamente encaixado aos desenvolvimentos do capitalismo durante a segunda metade do século XX. O próprio aparato de Estado, seu patrimônio e suas ações, tornaram-se ativos disponíveis à nova realidade do capitalismo global. Os movimentos de mercado, dessa forma, passaram a espelhar a própria atuação do Estado e é nessa particularidade que repousam as bases da primazia da dívida pública nas discussões contemporâneas sobre política econômica, consolidada ao longo das últimas três décadas.

O processo foi facilitado e, em grande medida, viabilizado pela ampla difusão de mecanismos financeiros no interior da sociedade. Ao fim e ao cabo, cada indivíduo, tornado empreendedor, passou a lidar, em sua vida cotidiana, com a naturalização dos ativos financeiros e com sua influência sobre a organização das finanças, sejam elas locais ou globais. Tratou-se de um verdadeiro processo de subjetivação, indispensável à reestruturação de forças sociais que viabilizasse as formas de dominação emergentes em um capitalismo altamente financeirizado. Afinal, compartilha-se, aqui, do ensinamento de Claus Offe:

O princípio de qualquer relação de dominação é o entrelaçamento complementar de instrumentos objetivos de poder e de coerção, com sistemas subjetivos de motivação, que a confirmam e reproduzem. A dominação não é imaginável como uma formação histórica duradoura, se não for considerada a consciência afirmativa daqueles que, mesmo não dominando, a aprovam e apoiam, ou pelo menos toleram (OFFE, 1975, p. 72).

No meio social difuso, o movimento de financeirização pode ser caracterizado da seguinte

forma:

\begin{abstract}
Nos anos 90, generalizou-se a consciência a respeito do peso e da influência dos ativos financeiros nas economias modernas. Isto não é surpreendente. Em pouco mais de uma década, desde o início dos anos 80 , a composição da riqueza social sofreu uma importante mutação. Cresceu velozmente a participação dos haveres financeiros na composição da riqueza privada. Nos países desenvolvidos as classes médias passaram a deter - diretamente ou através de fundos de investimentos ou de fundos de pensão e de seguro - importantes carteiras de títulos e ações. O patrimônio típico de uma família de renda média passou a incluir ativos financeiros em proporção crescente, além dos imóveis e bens duráveis. As empresas em geral também ampliaram expressivamente a posse dos ativos financeiros e não apenas como reserva de capital para efetuar futuros investimentos fixos. A "acumulação" de ativos financeiros ganhou na maioria dos casos status permanente na gestão da riqueza capitalista. (COUTINHO; BELLUZZO, 1998, p. 137)
\end{abstract}

Os efeitos macroeconômicos da forte injeção de crédito na economia foram evidentes: experimentou-se, em distintos lugares, um crescimento econômico baseado na conjugação entre déficits privados e forte expansão do crédito. A forma jurídica aparece, nesse processo, como um meio de consolidação dos elementos socioeconômicos que foram se estruturando ao longo das 
últimas décadas. Se, em um sentido negativo, o Estado recolheu seu papel regulador ao derrubar restrições legais à criação de novas figuras de crédito, ao mesmo tempo, foram evidentes os reforços positivos à economia creditícia. Como expõe Daniel Bin:

Não se nega que a presença estatal na economia diminuiu em certas atividades que tradicionalmente desempenhava, contudo, não se pode dizer o mesmo em relação à economia como um todo. Conforme destaca Biersteker (1990) ao analisar reflexos dos principais componentes dos programas de ajuste prescritos pelo FMI e pelo Banco Mundial, isso não se deu em todas as atividades e nem com a mesma intensidade em cada uma delas: i) a atuação no câmbio, no controle do estoque de moeda, ajuste fiscal e mesmo a liberalização comercial e financeira eram questões tendentes ao aumento ou, no mínimo, manutenção da influência estatal na macroeconomia; ii) da mesma forma, acreditava-se na manutenção de um Estado ativo na mediação dos conflitos entre capital e trabalho; (iii) funções como produção e planejamento foram sim reduzidas, e a regulação que se dava por essas vias foi convertida em apoio ao investimento privado, isso tudo materializado pela privatização; e iv) a função de redistribuição dos frutos da produção tenderia à redução via fim dos subsídios, dos controles de preços e de eventuais indexações salariais ou tenderia ainda a um redirecionamento causado por alterações no contexto econômico. (BIN, 2010, p. 72)

Os próprios Estados passaram a reproduzir o contexto competitivo empresarial, em busca da formação de hegemonias regionais, em movimentos neoimperialistas e subimperialistas. Assim, transmitiam para o âmbito nacional as pulsões próprias da realidade oligopolista ou competitiva do capitalismo.

Mas a virada para a financialização envolveu muitos custos internos [para os Estados Unidos], como a desindustrialização, as fases de rápida inflação seguida pelo esmagamento do crédito e o desemprego estrutural crônico, exceto em setores como a defesa, a energia e o agronegócio. A abertura dos mercados globais de mercadorias e de capital criou ranhuras por onde outros Estados se inseriram na economia global, primeiro para absorver mas depois para produzir capitais excedentes. Esses Estados tornaram-se então competidores no cenário mundial. Surgiu aquilo que se pode denominar "subimperialismos", não só na Europa mas também no Leste da Ásia e no Sudeste Asiático, à medida que cada centro em desenvolvimento de acumulação do capital buscava ordenações espaçotemporais sistemáticas para seus próprios capitais excedentes mediante a definição de esferas territoriais de influência. Porém, estas últimas eram antes sobrepostas e interpenetrantes do que exclusivas, refletindo a facilidade e a fluidez da mobilidade do capital no espaço e as redes de interdependência espacial que ignoravam cada vez mais as fronteiras do Estados. (HARVEY, 2013, p. 151)

Nesse contexto, a segregação entre atos de império e atos de gestão ganha contornos especialmente curiosos. É por assumirem a lógica empresarial, em grande medida, que os Estados passam a diferenciar suas ações entre as de nível soberano - aquelas heterônomas, que implicam uma atuação direta, normativa, geral e abstrata, que para o discurso do senso comum aparece como uma continuação do exercício da soberania - e as de nível gerencial - definidas conforme as metas burocraticamente definidas de crescimento econômico e distribuição de rendimentos.

O endividamento público ocupa lugar de destaque nessa sistemática. É esse o modo principal, ao menos nos mercados latino-americanos - como a Argentina e também o Brasil -, de 
inserção do aparato estatal de governo nos mercados financeiros, tornando a população afetada pelas políticas sociais diretamente afetada pelos ciclos de expansão ou retração financeira. No interior dessa sistemática, a política de juros - elemento típico dos controles macroeconômicos que caracterizam a governamentalidade neoliberal - desempenha um papel especialmente relevante: os juros são a forma como nossa sociedade naturalizou, em grande medida, o crescimento do rendimento em decorrência do passar do tempo. Passou, assim, a ser um instrumento "legitimado por uma lógica de remuneração 'natural' do capital-dinheiro” (BIN, 2010, p. 112).

No interior da teoria econômica de viés crítico, os juros têm sido compreendidos como fundamento de "transferência de mais-valia entre classes", uma "noção abstrata que naturaliza a existência de explorados e exploradores que, numa palavra, vivem no mesmo momento histórico" (BIN, 2010, p. 113). Na economia contemporânea, a centralidade dos mercados financeiros globalizados, deslocados espaço-temporalmente das estruturas nacionais, e nos quais os juros constituem o próprio fundamento de manutenção dessa estrutura, não é difícil perceber que “crises da dívida podiam abalar o Brasil e o México, crises de liquidez podiam destruir as economias da Tailândia e da Indonésia, mas elementos rentistas desses países puderam não só preservar seu capital como na verdade melhorar sua posição de classe” (HARVEY, 2013, p. 151). Partindo-se desse pressuposto de estruturação econômica da economia da dívida, verifica-se com igual simplicidade que o Estado, na medida em que ocupa o papel de emissor de títulos posteriormente comercializados em mercados primários e secundários torna-se um dos gestores dessa organização. E mais que isso: uma vez que congrega atribuições de gestão e império, suas políticas terminam por afetar um universo bastante extenso de sujeitos.

O Estado argentino, como visto no Capítulo 2, adotou, ao longo de três décadas, uma ativa postura neoliberal, articulando desregulamentação dos mercados de capitais com uma vigorosa expansão do crédito público. Ainda: com a transmutação de dívida externa em dívida interna especialmente promovida pelo chamado Plano Brady - tornou-se mais dependente de taxas de juros vinculadas a flutuações de mercado. Nesse contexto, o papel dos poderes públicos - ao menos no nível da discussão pública - passa a ser o de gerenciar juros de modo a manter certo nível dito "sustentável" de endividamento, capaz de assegurar, a um só tempo, a continuidade dos ganhos 
privados de credores da dívida e certo padrão social de investimento público ${ }^{32}$. Não raramente, esse esforço conjugado leva a contradições e crises, como aquela que ocorreu no caso da Argentina.

Trata-se de característica típica do capitalismo, no qual "as formas de sociabilidade se estruturam em relações de exploração, dominação, concorrência, antagonismo de indivíduos, grupos, classes e Estados", constituindo-se um pano de fundo sobre o qual "se assentam eventuais ciclos de estabilidade e continuidade no campo da reprodução social, política e econômica capitalista (MASCARO, 2013, p. 111). Essas contradições se acentuam no campo do endividamento público, em que se lida com a política orçamentária a ser adotada para a obtenção de um crescimento econômico sólido e equilibrado (BENAKOUCHE, 2013). No caso específico da Argentina, as crises desencadeadas pelo alto endividamento contraído ao longo da euforia neoliberal no país, especialmente quando sob a batuta de Carlos Menem, tornaram as contradições ainda mais visíveis aos olhos comuns.

De fato, principalmente a partir dos anos 1990, a gerência do endividamento argentino se deu mediante a redução do déficit público, operacionalizada por meio de uma política de desfazimento dos ativos públicos e da privatização de parcela relevante do aparato estatal (DAMILL; FRENKEL; RAPETTI, 2005). Esse modo específico de gestão das finanças do Estado busca seu respaldo na tese dos economistas clássicos, para os quais "se o caixa do Estado está vazio, então o Estado está falido - ou seja, ele não dispõe de uma poupança suficiente para financiar sua política econômica" (BENAKOUCHE, 2013, p. 145). Trata-se de uma crença em que a poupança pública é geradora do investimento, uma visão que desafia a própria existência de um sistema monetário nacional. Isso porque é a economia monetária que viabiliza o crédito bancário e este, por sua vez, torna possível a formação de poupanças que, investidas no mercado financeiro, viabilizam o empréstimo ao Estado sob a forma de títulos da dívida pública (BENAKOUCHE, 2013).

O comportamento do Estado argentino, insistindo no receituário da austeridade para conter os níveis de endividamento e estimular a poupança, mostrou seus limites. A dívida não parou de crescer e, pior, cresceu muito mais aceleradamente que o produto nacional, forçando a realização de uma escolha política entre a manutenção dos pagamentos aos credores e a preservação do

\footnotetext{
${ }^{32} \mathrm{Na}$ Europa e na América Latina democráticas, esse foi um discurso que, ao longo do tempo, teve ao menos um respaldo público relevante (embora, na prática da América Latina, o favorecimento das finanças sempre tenha sido prevalecente). Trata-se de um discurso que encontrou força no respaldo da tese do Estado social, que "fez sua a herança dos movimentos burgueses de emancipação - o Estado constitucional democrático" (HABERMAS, 1987, p. 106).
} 
investimento social, criando uma situação crítica de contradição social, à qual o sistema capitalista vigente pôde se adaptar com alguma facilidade, passando ao largo de qualquer ruptura mais relevante.

Aqui, a questão óbvia emerge: como é possível que algo inerentemente contraditório exista na realidade histórica? Como ela pode se tornar operativa como um modo de produção? A sua existência (e sua duração ao longo do tempo) invalida o conceito de contradição, como aplicado a um modo de produção? Essas conclusões paradoxais somente podem ser evitadas se nós partimos dos seguintes pontos:

1. as contradições estruturais de um modo de produção capitalista não são uniformes ao longo da história de um desenvolvimento capitalista, mas se tornam maiores e mais profundas conforme a acumulação se desenvolve;

2. o conceito de "contradição não implica uma "ruptura" ou uma "crise" automática do modo de produção capitalista.

Em outras palavras, as tendências autodestrutivas do modo de produção capitalista se desenvolvem em um processo histórico, e seu potencial destrutivo e revolucionário pode ser bem controlado e mantido em latência por meio de vários mecanismos adaptativos do sistema, ao menos temporariamente. A expectativa de que a habilidade para reconciliar contradições emergentes por meio dessas medidas adaptativas seja limitada, e de que as contradições finalmente resultarão em uma crise do modo de produção capitalista, não é baseada em esperanças utópicas, mas na consideração de que nenhum ator ou agência no interior do modo de produção capitalista é suficientemente desafetado por essas contradições que precisam ser reconciliadas para ser capaz de agir de tal forma que as neutralize (OFFE, 1984, p. 133, tradução livre).

A adaptação à situação que desembocou na crise de 2001-2002 envolveu, já no primeiro momento de enfrentamento mais forte à crise e, em seguida, no governo de Néstor Kirchner, um redirecionamento dos pagamentos do país que envolvia um reposicionamento governamental que objetivava reconciliar a eficiência de Estado à legitimidade pública que havia sido severamente abalada com as perdas econômicas decorrentes do elevadíssimo padrão de endividamento. É certo que, em alguma medida, a renegociação da dívida argentina representou uma alteração em relação ao que esperavam entidades como o FMI, o Banco Mundial e as agências internacionais de classificação de risco. No entanto, é relevante recordar que o processo foi negociado e, se a Argentina se aproveitou de condições econômicas específicas que lhe foram benéficas, atuou justamente nos limites daquilo que qualquer agente privado no interior de uma economia capitalista também faria - não nos parece estranha, afinal, a fórmula da renegociação, a qual pode ser preferível a credores e devedores mesmo em situações que não envolvam pagamentos efetuados por um Tesouro Público.

A reestruturação da dívida, mediante descontos que incidiram sobre os juros devidos pelo Estado argentino, foi verdadeiro ato de gestão em face de uma situação para a qual o receituário neoliberal não atingira solução politicamente respaldável. Referido receituário malfadado representou a aplicação institucional de premissas caras a um segmento acadêmico que ascendeu a 
cargos burocráticos, formado por representantes de um mainstream econômico (NEIBURG, 2005) que eram a corporificação da articulação entre exercício do poder político e formulação de verdades a respeito dos fatos da vida econômica.

A questão, no entanto, fica um tanto mais sensível ao se refletir a respeito do significado do ato de preterimento dos credores que recusaram a negociação realizada entre a Argentina e a maior parcela de seus devedores. As decisões judiciais analisadas apreciaram a questão sob distintas perspectivas. Na Itália, entendeu-se que a decretação do estado de emergência nacional pela Argentina era um ato soberano com finalidade de ordem pública, chegando-se até mesmo a falar em uma "proeminência absoluta dos interesses da coletividade organizada sob a forma de Estado" (CORTE SUPREMA DI CASSAZIONE, 2005, tradução livre) - para se reorganizarem as finanças do país, justificava-se a imposição de critérios específicos de pagamentos aos credores, os quais não poderiam ser reapreciados por uma corte estrangeira. Por outro lado, na Alemanha, compreendeu-se que não havia, na hipótese, um regime de direito público que pudesse incidir de modo a excluir, por livre determinação estatal, a imperatividade do pagamento integral devido aos credores privados. Nos Estados Unidos, foi propriamente um discurso de igualdade de tratamento que prosperou: os credores que não aceitaram a reestruturação da dívida deveriam ser pagos quando do vencimento dos seus títulos, ainda que isso pusesse em xeque a integridade da negociação estabelecida com a larga maioria. Mais que isso: o Poder Judiciário dos Estados Unidos da América sequer garantiria a imunidade de execução que protegeria os bens da República Argentina qualquer tentativa de preterimento dos chamados fundos abutres implicaria o bloqueio dos bens do Estado devedor nos bancos de Nova Iorque, onde se realizavam os pagamentos, por disposição contratual.

Em nenhum dos casos a emissão de títulos da dívida pública foi compreendida como um ato de império. Portanto, à luz da compreensão da conformação constitucional vislumbrada por aquelas cortes, a existência de uma obrigação financeira cujo devedor é um Estado não representa uma concretização da soberania, mas a efetiva inserção de poderes públicos na lógica de mercado, implicando, ainda que indiretamente, na relação creditícia, aqueles indivíduos e grupos que se encontram sob o manto desse mesmo Estado. Nesse ponto, é necessário enfatizar que isso implica que os cidadãos, especialmente aqueles dependentes de políticas sociais e serviços e utilidades públicos, restam à mercê dos juros e das apostas que credores realizam sobre o comportamento econômico do Estado. Isso porque, embora emitidos com certo valor de face, os títulos públicos 
têm taxa de remuneração (juros) variável, dependente das oscilações de mercado operadas pelos próprios credores, podendo chegar a valores estratosféricos, como aqueles alcançados pelos títulos detidos por credores que acionaram as cortes norte-americanas.

O Estado acaba por ter um papel relevante na dinâmica das trocas de capital da contemporaneidade, não exatamente por meio do investimento público preconizado pelos teóricos keynesianos, tampouco pelos intervencionismos dito "populistas" que tiveram algum reforço recente nas políticas dos países subdesenvolvidos para promover alguns níveis de inclusão socioeconômica. No contexto global do capitalismo financeiro, é propriamente por meio de sua intervenção nos sistemas de crédito, lançando títulos financeiros nos mercados, que os Estados se tornam operadores dessa dinâmica. As políticas sociais globais, assim como os ajustes econômicos das disparidades e a consecução de metas sociais tornam-se possíveis, no nível do discurso, mas sobretudo nas práticas políticas, na medida em que garantida a estabilidade dos sistemas financeiros em que se inclui determinado aparato estatal. A emergência de um tal contexto foi possível por conta da convergência de fatores ligados à hegemonia financeira de determinadas instituições, mas também e principalmente, devido à ampla difusão dos mecanismos de mercado nas vidas das pessoas. Assim, são esses mecanismos que acabam articulando os instrumentos de gestão pública da economia fortemente financeirizada que caracteriza a realidade capitalista atual.

\begin{abstract}
A perda de confiança nos símbolos do dinheiro (o poder do Estado para garantir estabilidade monetária) ou na qualidade de dinheiro (inflação) leva à possibilidade de escassez monetária e ao congelamento dos meios de pagamento, do tipo que ocorreu no outono de 2008. No coração do sistema de crédito, existe uma gama de aspectos técnicos e jurídicos (muitos dos quais podem falhar ou ser distorcidos, simplesmente por suas regras de funcionamento), aliada a expectativas e antecipações subjetivas. Na medida em que o capitalismo continua a se expandir, o papel do sistema de crédito se torna mais proeminente, como uma espécie de sistema nervoso central para dirigir e controlar a dinâmica global da acumulação do capital. A implicação é que o controle sobre os meios de crédito torna-se crítica para o funcionamento do capitalismo - uma situação que Marx e Engels reconheceram no Manifesto Comunista, fazendo com que a centralização dos meios de crédito nas mãos do Estado fosse uma de suas demandas essenciais (presumindo, é claro, o controle da classe trabalhadora sobre o Estado). Quando isso é adicionado ao papel fundamental do Estado no que diz respeito à qualidade da cunhagem e, mais importante, das moedas simbólicas, então uma maior fusão de poderes estatais e financeiros no nexo Estadofinanças parece inevitável. (HARVEY, 2011, p. 98)
\end{abstract}

Nesse contexto, operacionalizar o aparato jurídico que dá suporte às modernas constituições torna-se algo facilitado mais pela emergência dos poderes articulados por meio da tríade Estado - finanças - vida financeirizada do que pela força de uma normatividade dos direitos prescritos em documentos jurídicos, eles próprios expressões cristalizadas de certas hegemonias sociais cujo estabelecimento foi possível nas origens do liberalismo clássico. 
A ampliação da lógica financeira para diversas esferas da vida em sociedade, com destaque para o Estado, aparentemente teria confirmado o desejo liberal e a prescrição neoliberal de que ao Estado não caberia intervir na economia. Mas os Estados se mantiveram presentes e a crise do liberalismo keynesiano, nesse sentido, não fez mais do que ser substituída por um novo liberalismo. Como o liberalismo anterior, o neoliberalismo não prescindiu do Estado, ainda que fosse ele o destinatário de seus discursos mais agressivos. Discursos esses apoiados ainda pela teoria econômica que finalmente conquistava o espaço tomado pelo sucesso prático de sua adversária keynesiana. (BIN, 2010, p. 250-251)

Nesse contexto, uma distinção como aquela lançada pelas decisões judiciais, entre atos de império e atos de gestão, acaba por omitir - ou por velar sob o manto do direito - os aspectos mais relevantes à compreensão política do problema, que não depende tanto da determinação da natureza ou da potência de uma decisão estatal, mas exatamente dos limites em que pode ser tomada essa mesma decisão. É que o direito, cumprindo de modo disciplinado o papel que lhe foi desenhado pela modernidade ocidental, não vai além da reprodução da linguagem que por ele se expressa: uma articulação de arranjos institucionais e administrativos que, independentemente do nome que recebem, são dotadas de significações sociais ampliadas, expressões consolidadas e conservadas pela forma jurídica.

Todas essas "esferas de atividade" estão incorporadas em um conjunto de arranjos institucionais (como os direitos de propriedade privada e os contratos de mercado) e estruturas administrativas (o Estado e outros arranjos locais e multinacionais). Essas instituições também evoluem por conta própria, até mesmo quando são forçadas a adaptar-se a condições de crise (como acontece agora) e a mudanças nas relações sociais. As pessoas agem, além disso, de acordo com suas expectativas, suas crenças e sua compreensão do mundo. Os sistemas sociais dependem da confiança em especialistas, do conhecimento e da informação adequados daqueles que tomam decisões e da aceitação razoável dos arranjos sociais (hierárquicos ou igualitários), bem como da construção de padrões éticos e morais (...). As normas culturais e os sistemas de crenças (ou seja, ideologias religiosas e políticas) são muito presentes, mas não existem independentemente das relações sociais de produção, das possibilidades de produção e consumo e das tecnologias dominantes. As inter-relações em conflito entre as necessidades de evolução técnica e social para a acumulação do capital e as estruturas de conhecimento e normas e crenças culturais compatíveis com a acumulação infinita têm desempenhado um papel fundamental na evolução do capitalismo. (HARVEY, 2011, p. 103-104)

É nesse aspecto que a forma constitucional se torna particularmente relevante aos desenvolvimentos dos direitos de crédito. Conforme já se expôs, o constitucionalismo, expresso pela tese de proteção a direitos de indivíduos por instituições com poderes limitados, conquanto tenha se esforçado por associar-se ao discurso democrático (especialmente por meio da tese do poder constituinte popular), terminou por se tornar, na contemporaneidade, expressão preponderante da tese liberal do rule of law (COSTA, 2011). E precisou, para tanto, desnaturar por completo a tese da soberania, até porque, após a promulgação de uma constituição que consolide e 
conserve determinada ordem social, fruto das expressões de uma violência fundante, é a esse texto original que se faz remissão a cada decisão política relevante.

Apoiada na potência do momento original, a qual se encerra após a sua promulgação, a constituição não apenas possibilita que um povo dê a si mesmo um nome próprio. Ela, em seu momento fundante, torna a si mesma "o fundamento de validade da ordem jurídica, pois é feita com a intenção de resguardar, tanto em seu texto quanto em sua vigência como decisão política, a violência mística do ato que instituiu o direito" (THEODORO FILHO, 2011, p. 68). É com referência à sua assinatura e em seu nome que, em substituição às ordens valorativas que antes da modernidade imperavam como referência do pensamento e da prática hegemônicas ocidentais, a constituição consolida a substância das relações jurídicas encetadas pela modernidade. Esse conteúdo ganha contornos de definitividade, especialmente porque a manutenção da referência ao momento constituinte esvazia a potência instauradora do direito (AGAMBEN, 2014). No dizer de Walter Benjamin:

Um olhar dirigido apenas para as coisas mais próximas perceberá, quando muito, um movimento dialético de altos e baixos nas configurações da violência enquanto instauradora e mantenedora do direito. A lei dessas oscilações repousa no fato de que toda violência mantenedora do direito acaba, por si mesma, através da repressão das contraviolências inimigas, enfraquecendo indiretamente, no decorrer do tempo, a violência instauradora do direito, por ela representada. (BENJAMIN, 2013, p. 155)

O modo como o direito impõe a sua força - e, aqui, falamos dos elementos conformadores do constitucionalismo contemporâneo, em especial a separação dos poderes e a supremacia constitucional - precisa ser apreciado para que se tenha uma compreensão sólida a respeito do modo como a forma jurídica representa, para além das abstrações jurídicas que são evidentes, relações sociais complexas, fluxos de poder que são imprescindíveis para o estabelecimento de dominações sociais (PACHUKANIS, 1988). A forma do constitucionalismo foi o modo ideal para que, a partir da emergência de uma impessoalidade que absorve os poderes da soberania e que reproduz a dinâmica específica de mercado, o conteúdo dos direitos repercutisse menos pelos seus efeitos e pelas noções comunitariamente compartilhadas de justiça, enfatizando-se a consolidação histórica e a projeção para o futuro dos mecanismos de poder bem sucedidos por meio da potência constituinte. Lúcida, nesse sentido, a análise de Pachukanis, para quem a construção das formas jurídicas segue, em grande medida, a conformação das forças que efetuam trocas no interior da sociedade burguesa.

Na medida em que a sociedade representa um mercado, a máquina do Estado estabelece-se, com efeito, como vontade geral, impessoal, como a autoridade do direito etc. No mercado, como já 
foi visto, cada consumidor e cada vendedor é um sujeito jurídico por excelência. Nesse momento, quando entram em cena as categorias do valor e do valor de troca, a vontade autônoma dos que trocam impõe-se como condição indispensável. $\mathrm{O}$ valor de troca deixa de ser valor de troca, a mercadoria deixa de ser mercadoria quando as proporções da troca são determinadas por uma autoridade situada fora das leis inerentes ao mercado. (PACHUKANIS, 1988, p. 97-98)

O primado das teses contratualistas, que estão na base do constitucionalismo liberal, evidencia que a filosofia política moderna privilegia as concepções privatísticas das relações sociais. A sociedade deixa de ser pensada como uma entidade à qual as pessoas estão vinculadas por relações naturais, e passa a ser concebida como o resultado de uma decisão estratégica de indivíduos motivados por seus interesses pessoais, constituindo uma unidade artificial cujo fundamento é a própria autonomia contratual. Não é por acaso que, para Hobbes, a autonomia para contratar (lida juridicamente pelo brocardo do pacta sunt servanda) é um dos principais mandamentos do direito natural: "sem esta lei os pactos seriam vãos, e não passariam de palavras vazias; como o direito de todos os homes a todas as coisas continuaria em vigor, permaneceríamos na condição de guerra" (HOBBES, p. 123). Esse tipo de posicionamento justifica plenamente a percepção de Benjamin Constant de que, enquanto os antigos chamavam de liberdade a "partilha do poder social entre todos os cidadãos de uma mesma pátria", o objetivo dos cidadãos modernos "é a segurança dos privilégios privados; e eles chamam liberdade as garantias concedidas pelas instituições a esses privilégios" (CONSTANT, 1819). Não se trata da instituição de um poder público que governe a coletividade em nome do bem comum, mas de uma estrutura política que proteja os indivíduos do próprio governo, blindando o direito tradicional (ou seja, uma peculiar combinação de direito costumeiro e direito romano) contra a intervenção dos governantes e permitindo que, nos quadros da tradição herdada, cada indivíduo busque o seu próprio bem.

A modernidade do direito (europeu) tem esvaziou o conteúdo político das normatividades, compatibilizando a centralização política (que viabilizou a superação das guerras civis de caráter religioso) com a segurança das relações privadas (cuja regulação foi excluída do campo de ação dos governantes). O direito público deveria ser fruto da decisão política dos governantes (incumbidos de efetuar a guerra e manter a paz), mas o direito privado deveria encontrar suas fontes em outros espaços: na racionalidade implícita no direito romano, nos costumes da lex mercatória, na estabilidade das tradições, do common law, do law of the land. A razão de Estado existia para as questões públicas, que transcendiam a competência de instituições judiciais cujo papel era o de julgar as pessoas privadas, nos seus delitos criminais ou nas suas relações civis. No âmbito do 
direito civil, a missão fundamental dos magistrados era preservar a segurança no acesso a direitos (curiosamente denominados "privilégios" por Benjamin Constant) gozados privadamente.

No discurso constitucionalista, a própria lei - expressão teórica da soberania nas raízes do direito ocidental - se torna instrumento do modo como deve ser regida toda uma sociedade. A lei deixa de ser a expressão de um poder soberano, tornando-se, por excelência um instrumento de um governo entendido em termos rouseaunianos: um governo que não é soberano, mas que é simples magistrado. Um governo que tem por função gerir, e não legislar, ao menos sobre os temas básicos da organização social, que são definidos de uma vez por todas por um texto constitucional miticamente referido ao exercício direto do poder legislativo do povo (relido como poder constituinte, na estrutura conceitual proposta por Sieyès). Esse governo moderno assume a forma de uma estrutura de gestão, composta por aparatos administrativos e jurídicos bem compartimentados, não totalizáveis, modelados em um sistema de pesos e contrapesos que impede qualquer ação rumo a objetivos que não sejam unânimes. O objetivo explícito dessa conformação não é a de garantir o bem comum e a vontade geral, mas de garantir a liberdade individual (ou seja, os direitos tradicionais) contra exercícios de poder que se pretendam soberanos.

A operacionalização do discurso em torno da pirâmide normativa se dá a partir dos padrões de um aparato tecnológico de construção de um senso comum teórico, o qual, conforme ensinamento de Luis Alberto Warat, resulta do "emprego estratégico dos conceitos na práxis jurídica", resultante do processo de purificação de hábitos significativos (doxa) que reincorpora os conceitos nesses hábitos. Segregados das teorias das quais emergem, esses conceitos permitem a constituição de um sistema de verdades, "o qual não está vinculado a conteúdos, mas sim, a procedimentos legitimadores, determinantes para o consenso social” (WARAT, 1982, p. 55). Assim é que, por meio de um procedimento referenciado em normas que sejam imediatamente superiores e pela imposição da autoridade final de quem decide, afasta-se toda possibilidade, na modernidade de direito, de um ato que efetivamente seja de império. No discurso constitucionalista, somente o povo tem o direito de praticar atos de império, e o único ato de império verdadeiramente aceito é a instituição do texto constitucional. Todos os outros atos legislativos, ainda que tenham uma grande margem criativa, precisam ser compreendidos como aplicadores daquelas normas basilares contidas na constituição. Os elementos conformadores do direito, a separação e a limitação de poderes por ele engendradas, tornam-se o velo necessário à emergência da governamentalidade liberal nas sociedades ocidentais em que esse paradigma se fez hegemônico. 
$\mathrm{Na}$ visão clássica, o poder soberano tinha a possibilidade de praticar atos de império, efetivados em termos de uma razão de Estado que os excluía de qualquer controle, visto que eram legibus solutus. Na visão constitucionalista, o exercício do governo é reduzido a um ato de gestão, mas é um ato de gestão peculiar, que pode atuar em nome do povo para criar direitos e obrigações, que seriam atividades percebidas como exercício de soberania, e não de uma simples magistratura. A criação desses atos de gestores investidos de poder de império conduziu a necessidade de distinguir, nos atos do governo, aqueles que são de império ou gestão. Ocorre, porém, que essa divisão binária é corroída pelo fato de que todo ato de um governo constitucional é parcialmente criador, parcialmente aplicador. Como aponta Kelsen, a distinção entre a sentença judicial e a legislação não é de natureza, mas de grau: o poder criador do legislativo é mais amplo que o dos juízes, mas não é ontologicamente diverso.

Essa impureza essencial dos atos de governos constitucionais torna opaca a velha distinção entre império e gestão, e reduz essa distinção a um problema dogmático. Atribuir uma dessas classificações a um ato não significa falar nada sobre ele, mas apenas definir quais são as consequências jurídicas que atribuímos a ele. A resposta constitucionalista parece apontar no sentido de esvaziar o conteúdo de império (que só não é anulado porque ainda é preciso tomar decisões), fenômeno que se tem radicalizado na medida em que o controle judicial de constitucionalidade trata as leis como atos de gestão, vinculados estritamente à leitura correta do conteúdo das leis. Não deve causar espanto que cortes constitucionais ativas tenham pouco apreço pela noção de ato de império, categoria cujo esvaziamento está na base da afirmação do seu próprio poder. Não se trata apenas de desconsiderar a validade de atos praticados por outros Estados, mas de afirmar uma racionalidade comprometida com uma postura política que percebe nos governos, fundamentalmente, gestores de estruturas normativas estabelecidas por atos de império.

Na temática do endividamento público, essa perspectiva conduz a resultados paradoxais. A divida soberana só pode ser uma contradição, pois os atos soberanos de império não podem abrir mão do caráter legibus solutus do poder soberano, e não pode haver uma dívida sem obrigação de solvê-la. A constituição de uma dívida soberana somente pode ser um ato de gestão, pois se assim não fosse o vínculo obrigacional restaria inexistente, mas o ato de gestão somente pode ocorrer dentro dos quadros de um direito maior. A validade da dívida soberana exige que se considere que devedor e credor façam parte de um mesmo sistema jurídico, com normas heterônomas que 
regulam os seus direitos e deveres, especialmente a possibilidade de execução. Portanto, a dívida soberana somente pode ser uma dívida não soberana.

O dever de cumprimento de tais contratos insere-se na lógica de reprodução social do capital e o direito, reproduzindo a dinâmica da teoria do valor que explica o funcionamento das economias capitalistas, torna-se elemento legitimador, justamente por retirar sua legitimidade do momento fundante de sua própria autoridade. Daí decorre a grande dificuldade que mesmo decisões favoráveis aos interesses da Argentina, como é o caso da decisão italiana, enfrentam de assumir, numa perspectiva jurídica, a possibilidade das remodelagens das dívidas, em sentido contrário ao melhor interesse de credores. A lógica inversa representaria uma desestruturação do modo como pensado o sistema do direito - a favorecer a implicação dos devedores em juros determinados

segundo a justiça do mercado - e poderia até mesmo servir de "perigoso" precedente para outros programas de reestruturação.

\subsection{Que exceção como alternativa? Os limites do argumento do estado de emergência.}

Diante desses elementos, a única resposta plausível que as cortes cujas decisões foram analisadas puderam buscar no sentido de eventualmente favorecer os interesses da Argentina residia na suscitação de um estado de emergência, a justificar a excepcional possibilidade de se sustarem parcialmente os pagamentos aos credores. Essa é uma categoria interessante, pois não aponta para o caráter soberano da moratória, mas busca estabelecer um princípio geral de direito que poderia ser utilizado para justificar a licitude de um ato excepcional. Afirmar a validade da dívida soberana implica afirmar a validade de um sistema jurídico que regula os direitos e obrigações assumidos, e discutir a licitude da moratória com base no estado de emergência significa desenvolver hermeneuticamente os limites desse meta-direito. Nesse contexto, o topos retórico da emergência aparece como um argumento que prima facie poderia ser admitido por todos os participantes como candidato potencial a um dos princípios gerais. A ideia de que as obrigações podem ser descumpridas em situações excepcionais parece um complemento "natural" do pacta sunt servanda, e todos os ordenamentos jurídicos envolvidos nos casos citados têm regras de excepcionalidade para situações emergenciais.

$\mathrm{O}$ argumento do estado de emergência aparece tanto na decisão alemã quanto na decisão italiana. De fato, do que se extrai das decisões, mesmo no caso dos Estados Unidos da América, 
foi nesse aspecto, sobretudo, que a Argentina se arvorou para sustentar que as medidas eram justificáveis diante situação fática de caos econômico verificada no país. Tal argumento foi parcialmente acolhido na decisão italiana e, no caso da corte alemã, foi extensamente considerado, ainda que para se mencionar que não seria aplicável a uma relação jurídica de índole creditícia. Somente na exceção, fora de um contexto constitucional, é que se poderia pensar uma suspensão temporária dos direitos de crédito.

A questão que se punha às cortes que apreciaram a questão do endividamento argentino dizia respeito a dois problemas elementares. Em primeiro lugar, cuidava-se de enunciar até que ponto os Estados podem promover reestruturações de suas dívidas públicas em razão de uma situação econômica tida por excepcional. Em segundo lugar, e talvez com mais precisão, demandava-se uma resposta judicial a respeito da possibilidade de essa situação excepcional abranger uma suspensão dos direitos dos credores da dívida argentina.

O problema da emergência surge sempre como um grande desafio ao constitucionalismo liberal hegemônico, baseado no estabelecimento de uma ordem política que suprime o conflito político e as situações excepcionais em nome da realização de uma ordem pacífica e de um Estado neutro. Carl Schmitt, revisitando a história do pensamento racional europeu entre os séculos XVII e XX, descreve um movimento forte de neutralização e despolitização que atinge distintos domínios do conhecimento, o que leva a uma supressão das dicotomias que marcariam, na visão do autor, a progressão desses próprios regimes de conhecimento.

Como mudança, a mais forte e a mais carregada de consequências de todas as mudanças espirituais da história europeia, considero o passo dado pelo século XVII partindo da tradicional teologia cristã até o sistema de um cientificismo "natural", o que, até os dias atuais, determinou a direção a ser tomada por todo desenvolvimento posterior. Sob a grande impressão causada por esse processo se encontram todas as "leis" generalizantes da história da humanidade, como a lei dos três estágios de Comte, a construção de Spencer sobre a evolução da era militar rumo à industrial e semelhantes construções histórico-filosóficas. No cerne dessa admirável mudança reside um motivo fundamental, elementarmente simples e determinante para séculos: a aspiração por uma esfera neutra. Após os inúteis debates e contendas teológicos do século XVI, a humanidade europeia procurou uma área neutra, na qual havia cessado a disputa e onde era possível se entender, se chegar a um acordo e a se convencer mutuamente. Destarte, foram deixados de lado os controvertidos conceitos e argumentações da tradicional teologia cristã e foi construído um sistema "natural" da teologia, da metafísica, da moral e do Direito. (SCHMITT, 2008, p. 96)

A forma da constituição foi exatamente o modo como o Estado liberal buscou infundir a tecnicidade no âmbito jurídico, por meio de uma pretendida associação necessária entre liberalismo e democracia - ou mediante a operação de "acoplamento estrutural" a que Luhmann faz menção (LUHMANN, 1990). Com isso, a liberdade termina por ganhar um viés essencialmente de negação 
das influências da esfera do político sobre a construção de um regime de legalidade, sufocando até mesmo a ideia de uma igualdade substancial (não universal) que, radicalizada a tese clássica da democracia, deveria ser assim adotada (FERREIRA, 2004). Uma vez mais, trata-se exatamente da completa colonização da democracia pelo liberalismo, a implicar, em nome da democracia, sua própria negação.

Em uma situação democrática ideal - e aqui usamos a expressão ideal menos em um sentido valorativo positivo, e mais em um sentido de realização plena da tese democrática -, tornase possível, de modo permanente, a lida com as situações de conflito extremo, porquanto viabilizadas as condições para a emergência do conflito político fundamental. Em contextos como esses, nos quais emerge a completa confusão entre direito público (ou direito político, nos termos oitocentistas mais precisos) e o fato político, entre a ordem política e as pulsões de vida e morte nutridas nas relações políticas mais radicais, é que se torna possível a constatação da emergência (AGAMBEN, 2011).

A emergência, por se encontrar em um estado de indeterminação entre o regime da legalidade e o regime dos fatos políticos, não pode ser apreendida por uma estrutura como a do constitucionalismo liberal. Isso porque, na emergência, a força se torna o critério do político, e não mais o consentimento - este último, sustentáculo de uma constituição liberal. Em razão disso, a situação de emergência pode ser lida à luz da tese do estado de exceção, uma vez que, não sendo um direito especial, torna-se uma suspensão de relevantes fundamentos da ordem jurídica, do modo como compreendida na racionalidade moderna hegemônica (AGAMBEN, 2011). No caso da Argentina, foi invocada uma modalidade especial de emergência, que transmite para os domínios do campo econômico a disputa de poder social. A emergência econômica está umbilicalmente ligada ao modo como se estrutura o regime flexível de acumulação do capital e às suas implicações sobre a dinâmica do direito contemporâneo.

Ao ativar sua memória constitucional, um jurista inserido no mindset hegemônico contemporâneo poderia facilmente descrevê-lo a partir da articulação constante entre direitos individuais de igualdade e liberdade e a prática institucional democrática. E, de fato, não é difícil encontrar quem o faça, a partir de uma leitura que, afirmando a autonomia sistêmica do direito e da política, busque na constituição a possibilidade de articulação desses campos a partir de uma leitura liberal do primeiro e democrático da segunda (CARVALHO NETTO, 2004; COSTA, 2006; HABERMAS, 2003; NEVES, 2009). 
Especialmente em países que passaram, ao longo do século XX, por processos de ruptura com ditaduras e autoritarismos, a construção de constituições que enunciavam a democracia pareceu conduzir a tempos em que a luta por implementação dos ditames constitucionais consistia no máximo que se poderia exigir da luta política. Tudo isso se fez a partir de alguns elementos essenciais, comuns a esses processos: (i) alteração das lideranças políticas que substituíssem as classes que dominavam a política institucional autoritária; (ii) afirmação do sufrágio universal de todos os indivíduos; (iii) afirmação da possibilidade de controle político de qualquer demanda social; (iv) ênfase nos direitos humanos individuais; (v) compromissos com projetos de universalização do acesso a direitos (BRUNKHORST, 2014).

Esses elementos se vincularam entre si mediante a figura do poder constituinte, que permitia que um significante vazio do povo permanecesse não ocupado ${ }^{33}$ (LACLAU, 2007), mas sempre pudesse ser invocado a fim de inaugurar novos direitos e novas prerrogativas, a partir da força das mobilizações políticas em torno de causas específicas (COSTA, 2006; QUEIROZ, 2013). Entretanto, os desenvolvimentos das teses neoliberais ocasionou, como já antes dito, a emergência de um mindset gerencial, que não apenas desalojou e reprimiu a articulação universalista antes denominada mindset kantiano, como também apropriou-se desse corpo conceituou para afirmar-se de modo ainda mais expressivo.

Se as constituições do século $\mathrm{XX}$ pretenderam conceder ao público em geral a possibilidade de controlar as decisões nos distintos aspectos do social - inclusive aquelas tomadas no campo econômico -, a assunção hegemônica de teses neoliberais e ordoliberais ocasionou a inversão dessa relação, deixando as constituições e outros ordenamentos jurídico-políticos à mercê das determinações econômicas, o que se fez, sobretudo, pelo fato de se forjar uma tese tecnicista, desmobilizadora da política, decorrente da emergência de regimes altamente especializados na economia e no direito contemporâneos (TEUBNER, 2003).

\footnotetext{
${ }^{33}$ Como retrata Marcos Vinicius Queiroz, a assunção de uma tese do povo como significante vazio no interior da tese de Laclau advém da percepção de limites internos do marxismo. "As formas jurídicas, políticas, artísticas e ideológicas são apenas maneiras pelas quais os homens e as mulheres tomam consciência do conflito fundamental residente na estrutura econômica. Por trás dessa argumentação, encontra-se o pressuposto de certa progressividade dos modos de produção, em que relações novas superiores substituem as antigas, já defasadas" (QUEIROZ, 2013, p. 20). Por outro lado, na tese de Laclau, "o sujeito surge (...) como a distância entre a indecidibilidade da estrutura e a decisão, em que o momento da decisão não reconhece um princípio de fundamentação exterior a si mesmo. No entanto, essa decisão (elemento ôntico) é uma decisão, é a tentativa de sempre fechar aquilo que estava aberto (elemento ontológico)" (QUEIROZ, 2013, p. 44).
} 
Essa inversão não poderia se dar sem que algumas condições fáticas estivessem postas. A constituição do estado social se deu mediante uma conciliação de interesses de classes sociais distintas, mediadas por um Estado em permanente disputa (HABERMAS, 1987), que viabilizava suas políticas por meio de dois mecanismos essenciais, sujeitos ao controle constitucional do público: a moeda (externamente) e a tributação (internamente). Assim, o Estado poderia impor maior taxação a pessoas com maiores posses ou desvalorizar sua moeda para viabilizar a concomitância do crescimento econômico e da distribuição de renda. No entanto, o movimento já descrito de ampliação do uso de instrumentos de crédito pelo Estado o tornou refém de medidas que favorecessem a utilização privada desses mesmos instrumentos de crédito. Moeda e tributação se tornaram verdadeiros acessórios, ou, no máximo, termômetros da segurança que poderia ser concedida a investidores privados em títulos públicos (BRUNKHORST, 2014).

Nesse novo contexto, a constituição econômica que, originalmente, movia-se no sentido de viabilizar um controle público das instituições capitalistas, terminou por se transformar na viabilização concreta de exercício do poder técnico da economia neoliberal sobre as instituições constitucionais. Não é possível, no entanto, enxergar essas duas posições em um conflito constante. $\mathrm{Na}$ verdade, não raramente, elas afirmam uma à outra, consolidando, de maneira estratégica e simultânea, direitos com respaldo constitucional e preceitos econômicos da acumulação capitalista.

É por conta disso que situações como aquela vivenciada pela Argentina no início dos anos 2000 aguardam o mesmo receituário utilizado nos momentos de crise aguda do capitalismo financeiro. Soluções vistas como constitucionalmente respaldadas são justamente aquelas que garantem a parcela de direitos textualmente previstos nas constituições interessantes a detentores do poder gerencial capaz de mover capitais apesar das fronteiras, especialmente no contexto de elevada financeirização atualmente vivenciado. É nesses direitos e nessa pretensa estabilização constitucional que atores como os grandes credores internacionais apoiam-se para sustentar seus interesses. Tais interesses, ao fim e ao cabo, restam ocultados pela própria figura da proteção constitucional a direitos como a propriedade, que acaba contribuindo para uma despolitização das decisões envolvidas na discussão.

O direito contemporâneo, afinal, tecnificou-se em torno da tese constitucionalista. Se é verdade que os construtos jurídicos da modernidade surgiram "da imputação da validade do direito a certas decisões (legislativas, judiciárias, administrativas)" (FERRAZ JR., 1980), é igualmente certo que a difusão da tese dogmática decisionista implicou a criação de um senso comum teórico 
que, afirmando e reafirmando uma doxa específica, "serve para reivindicar, miticamente, um lugar neutralizado para a própria atividade profissional" (WARAT, 1982, p. 52). O constitucionalismo, originalmente revolucionário, acabou por sucumbir, em grande e relevante medida, à tentação do hegemon - para que mantivesse sua força, cedeu espaço às circunstâncias do poder social dominante e, em articulação estratégica com este, foi bastante útil na despolitização dos discursos sobre a economia política.

Em face desse quadro, uma decisão como aquela que tomou o governo argentino, de não absolutizar os direitos dos credores, é facilmente tachada como uma medida de exceção. Aqui reside o absurdo da situação: enquanto que as exclusões ocasionadas pelo cumprimento rigoroso dos direitos de crédito (inclusive dos juros marcados pelo próprio mercado a quem interessam) não seriam uma exceção ao direito vigente, a decisão governamental que momentaneamente suspende pagamentos ou que os escalona ao longo do tempo torna-se a panaceia de ativação do aparato constitucional.

Os atos que constituíram a emergência econômica argentina, assim, seriam expressões de "um espaço anômico onde o que está em jogo é uma força de lei sem lei (que deveria, portanto, ser escrita: força de lei). Tal força de lei, em que potência e ato estão separados de modo radical, é certamente algo como um elemento místico, ou melhor, uma fictio por meio da qual o direito busca se atribuir sua própria anomia" (AGAMBEN, 2011, p. 61). Não é difícil, em face do hegemon erguido em torno do conceito de constituição e do conteúdo de direitos ali presente, mover instituições que resistam à imposição da força suspensiva da pretensa exceção.

A construção conceitual é engenhosa: interessa aos poderes dominantes que a situação que contraria suas pretensões de estabilização econômica não esteja regulada pelo direito. Assim, fora de qualquer regulação, ela se torna antijurídica e, invocados direitos fundamentais, tais como a propriedade ou as garantias do devido processo, reverte-se uma decisão estatal, independentemente do eventual respaldo público que possua. Outra não é a pretensão da redução dos poderes soberanos à tese liberal do poder constituinte. Tudo aquilo que escapa do esquema conceitual torna-se, assim, marginal, excepcional. Na melhor das hipóteses, afirma-se nas franjas dessa sistemática da tecnologia constitucional - como um exercício de um direito de império em decadência, como é o caso da decisão na corte italiana sobre o endividamento argentino. De resto, o que se tem é a afirmação de prerrogativas individuais contra o Estado - como se tornou explícito na decisão alemã. 
A questão, assim, reduz-se a saber se a emergência suscitada é ou não é apreciável à luz dos direitos constitucionais tutelados dos credores, os quais despertam preocupações sobretudo relativas à pretensa estabilidade do sistema econômico, dependente que este seria do preceito pacta sunt servanda. Nesse particular, os silenciamentos impressionam. Nenhuma consideração adicional é traçada sequer sobre um princípio basilar do direito dos contratos, complementar ao dever de cumprir o pactuado, qual seja, o equilíbrio econômico dos contratos (na formulação medieval, contractus qui habent tractum successivum et dependentiam de futuro, rebus sic stantibus intelliguntur). A motivação parece ser evidente: aqui, a exceção à aplicação do princípio de manutenção das condições fáticas sob as quais foram celebrados os pactos se deve à naturalização dos juros na economia contemporânea. Essa exceção ganha especial relevo quando se trata do Estado, que se tornou o garante supremo do risco empresarial, aventurando-se, ele próprio, na perspectiva empreendedora e se tornando a correia de transmissão dos prejuízos financeiros privados, socializados por toda a coletividade dependente de políticas sociais.

O esvaziamento político do teor decisório do direito, aliás, é ainda mais claro na decisão proferida pela Suprema Corte dos Estados Unidos da América. Ali, a operação adotada foi a seguinte: primeiramente, reconheceu-se que os títulos da dívida argentina eram exigíveis em sua plenitude - e não com os descontos do plano de reestruturação da dívida. Em segundo lugar, admitiu-se que não eram, no entanto, executáveis os ativos argentinos nos Estados Unidos. No entanto, na terceira etapa da operação racional-dedutiva daquela decisão, concluiu-se que tais ativos eram exigíveis fora dos Estados Unidos. Uma vez mais, nenhuma palavra é dedicada às prováveis consequências da insegurança provocada pela decisão a outros planos de reestruturação de dívidas públicas, tampouco quanto ao respaldo jurídico dos chamados fundos abutres, cujos ganhos são devidos justamente à bancarrota dos países endividados.

Na verdade, a decisão da Suprema Corte terminou por se mover progressivamente à discussão sobre a exigibilidade da obrigação, desvinculando-se da temática da validade da obrigação em si, esta garantida pelo fato de, nessa hipótese, o direito norte-americano substituir os instrumentos internacionais e se tornar uma verdadeira meta-norma da dívida.

Diante desses elementos, impõe-se questionar a quem interessa a caracterização, como atos de emergência, das medidas presidenciais que deram norte à Argentina no pós-crise. Embora tenha sido o principal elemento aduzido pelo Estado Argentino para defender a viabilidade do seu plano, o delineamento dos decretos emergenciais como atos de excepcionalidade econômica é 
facilmente contraposto pelo discurso hegemônico mediante a articulação da linguagem dos direitos liberais, a esvaziar por completo o sentido da soberania - seja ela aquela detida por um chefe de governo, seja a de respaldo popular que deu as bases da construção das modernas democracias constitucionais. Não por acaso, é o Poder Judiciário a instância de legitimação das garantias individuais econômicas em face das pretensões estatais de organização da economia. Nesse particular, convém mencionar a conclusão de Hauke Brunkhorst a respeito da operação promovida por ordoliberais e neoliberais para decapitar o legislador democráticos:

A terceira (e em termos de direito constitucional a mais crucial) ideia básica do ordoliberalismo é livrar-se do controle legislativo democrático. Aqui, ordo- e neoliberais coincidem novamente na aplicação de imperativos categóricos: Dê aos juízes o que você retirou do legislador democrático e do governo controlado pelo parlamento! Promova os juízes a guardiões funcionais de um direito meramente regulatório (Ordnungsrecht)! Nas palavras de Ernst Joachim Mestmäcker: "Die wichtigsten Aufgaben obliegen nicht der Legislative oder der Regierung, sondern der Rechtsprechung." ("As decisões mais importantes devem ser tomadas não pelo legislador ou pelo governo, mas pelos juízes'). A decapitação do legislador é o verdadeiro final da Revolução Francesa e da era política kantiana. Se isso realmente se torna verdade, esse seria o triunfo final da contra-revolução que, nesse caso, é uma contra-revolução à experiência de 1789 . Nunca mais um legislador poderá estar apto a realizar uma revolução novamente. Essa era a verdadeira mensagem de Margaret Thatcher. Em 2002, Alex Stone-Sweet pode formular somente que "na atual organização política plurinivelada da Europa, a soberania do legislador e o primado dos executivos nacionais estão mortos. Em concertação ou em disputa, os legisladores europeus governam com os juízes." Deve-se acrescentar que a combinação entre jurisdição nacional e transnacional foi reforçada reciprocamente, e, em certo sentido, a associação europeia de cortes constitucionais - Verfassungsgerichtsverbund (Udo Di Fabio) - reservou para si as funções mais básicas de todos os três poderes clássicos - ao menos nos tempos normais de constitucionalização evolucionária incremental e gerencial. (BRUNKHORST, 2014, p. 101)

Relegar à posição de exceção as medidas de organização econômica do governo argentino é torna-las externas às orientações do direito, como se o suspendessem, quando, na verdade, o que está em jogo é qual o regime de direito se torna aplicável.

A não ser que se excluam as circunstâncias fáticas da possibilidade formal de apreciação, como fez a corte italiana - e, ainda assim, reconhecendo a viabilidade da suspensão apenas enquanto durar a emergência mencionada -, a resposta do sistema jurídico provavelmente será aquela que responde aos poderes sociais dominantes. Em um tal cenário de seletividade, os meios de ação de um Estado planificador da economia se tornam severamente reduzidos em razão da prevalência de direitos privados respaldados sistemas normativos nacionais hegemônicos, os quais se tornam os únicos marcos da definição jurídica a respeito dos direitos de crédito. Isso emerge inclusive do fato de o foro no qual se exerce a jurisdição em disputas sobre os investimentos poder ser externo ao país que emite os títulos. Dessa maneira, as determinações do direito público 
democraticamente estabelecido restam esvaziadas em nome dos regimes jurídicos de proteção aos indivíduos nacionais dos países em que se processam as ações.

\subsection{Os direitos humanos entram na arena - as críticas à exigibilidade da dívida por um novo pleito de unidade em face da fragmentação dos regimes jurídicos autônomos.}

Diante desses elementos, não demora a surgir a questão: à luz do constitucionalismo das cortes, seriam, então, soberanas as dívidas assim denominadas? Aparentemente, a leitura das decisões judiciais que deram margem à construção deste trabalho induz uma resposta negativa. Ao menos nas decisões de Alemanha e Estados Unidos, nem mesmo por determinações formuladas por governos democraticamente eleitos ou por corpos legislativos que funcionem pela lógica numericamente majoritária, poderiam os países se abster de efetuar os pagamentos na forma requerida pelos mercados financeiros.

Se a alegação da emergência econômica parece pouco convincente à luz de um sistema jurídico racionalizado com pretensões de universalização, a oposição crítica à imperatividade dos pagamentos também conduziu a formulações teóricas construídas no interior dessa mesma racionalidade jurídica. Assim, foram diversas as vozes que, no interior de um corpo de significações da lógica dos direitos, buscaram articular respostas à univocidade das prerrogativas de crédito, especialmente por meio da linguagem dos direitos humanos. Trata-se de uma resposta que faz com que entrem em disputa dois regimes jurídicos especializados que, mesmo que no interior de um mesmo ordenamento jurídico, contendem para buscar fazer prevalecer um ou outro modo de compreensão jurídica dos problemas práticos postos aos tribunais.

O desencadeamento do processo de fragmentação dos distintos domínios do direito fez com que diversos campos criados para a regulação das relações especializadas entre sujeitos de direito cerrassem os olhos para os demais campos de construção de regramentos específicos. Como é de se esperar, multiplicam-se os conflitos decorrentes desse modelo operacional, em virtude da produção de normas contraditórias ou da interpretação contraditória das mesmas normas, a depender dos interesses que se objetiva tutelar. Esse fato tem conduzido a pleitos de unificação ou de construção de modelos conciliatórios entre as distintas áreas, em especial vindos de quem busca inspiração no modelo constitucional para o estabelecimento de hegemonias específicas no direito internacional. 
O discurso da fragmentação vem sendo utilizado, pelo menos, ao longo dos últimos dois séculos, das mais distintas formas, “ora como um pluralismo saudável ('diversificação'), ora como uma perigosa segregação ('fragmentação')" (MARTINEAU, 2009, p. 2, tradução livre). Mais recentemente, porém, as pesquisas na área têm se dedicado a abordagens que problematizem as disputas de poder que levam às polarizações em torno do tema. Detida sobre o problema, a Comissão de Direito Internacional (CDI) identificou o fenômeno como algo decorrente das transformações sociais recentes, que conduziram a uma especialização funcional dos sistemas sociais, a qual incrementou a diferenciação e a autonomização de segmentos distintos:

A fragmentação do mundo social internacional obteve especial atenção do direito em virtude do fato de se fazer acompanhar pela emergência de regras ou complexos de regras, instituições jurídicas e esferas da prática jurídica especializadas e (relativamente) autônomas. O que antes parecia governado pelo "direito internacional geral" se tornou o campo de operação de sistemas especializados como "direito do comércio", "direito dos direitos humanos", "direito ambiental", "direito do mar", "direito comunitário europeu" e mesmo outras áreas exóticas e altamente especializadas, como "direito dos investimentos" ou "direito internacional dos refugiados" etc. - cada uma possuindo seus próprios princípios e instituições (COMISSÃO DE DIREITO INTERNACIONAL, 2006, p. 11, tradução livre).

Do trecho anterior, pode-se diagnosticar uma identificação da fragmentação como o processo de recorte dos sistemas jurídicos “em regimes funcionais ou regionais voltados a públicos específicos, com interesses e um ethos singulares" (MARTINEAU, 2009, p. 4, tradução livre). Outras leituras similares indicam as raízes sociológicas do processo de fragmentação, fortemente vinculadas a uma despolitização de campos altamente especializados, que emergem umbilicalmente ligados a técnicas de decisão. Exemplo disso é o desenvolvimento traçado por Gunther Teubner:

O que podemos observar hoje em dia, em matéria de globalização, não é a sociedade mundial paulatinamente configurada pela política internacional, mas um processo extremamente contraditório, integralmente fragmentado de globalização, impulsionado pelos sistemas parciais individuais da sociedade em velocidades distintas. Em tais processos, a política não apenas perdeu o seu papel de liderança, mas regrediu nitidamente em comparação com outras áreas parciais da sociedade. Em que pesem toda a internacionalidade da política e todo o direito internacional, a ênfase da política e do direito ainda nos dias de hoje recai no Estado-nação (TEUBNER, 2003, p. 12).

Como se pode depreender dessa interpretação, os dilemas advindos da fragmentação estão relacionados com as mudanças do conceito de soberania pelas quais passaram as relações entre os agentes dos mais variados sistemas sociais de índole global. Assim, enquanto que a política e o direito tradicionais continuariam a se debruçar sobre a categoria do Estado-nação, os novos regimes especializados vão adquirindo independência suficiente para criarem seus códigos próprios de regulação sistêmica. Trata-se, portanto, de uma recolocação do problema da unidade no direito, de 
modo que este se revela não mais como o médium do confronto entre distintos corpos de interesse, cada qual com sua conformação e sua dinâmica interna, mas propriamente como uma colcha retalhada em distintos campos do conhecimento jurídico, que disputam a prevalência quando seus regimes particulares entram em conflito.

\subsubsection{A crítica de Sabine Schlemmer-Schulte ao abandono da retórica dos direitos humanos.}

Os defensores da mencionada tese inserem-se na dinâmica de uma ideia universal de direitos humanos, segundo a qual se deveria sobrepor o interesse público relativo a um corpo fundamental de regras e princípios em relação a interesses de ordem econômica vindos de particulares. Referido apelo é bem sintetizado por Sabine Schlemmer-Schulte, para quem as discussões movidas no âmbito da Suprema Corte dos Estados Unidos da América e do Tribunal Federal Constitucional alemão teriam passado ao largo de elementos centrais que poderiam ter ensejado uma melhor compreensão das posições adotadas pela Argentina.

A autora sistematiza algumas sugestões para, nas suas palavras, "remediar o problema específico da fragmentação resultante das crises financeiras de países em desenvolvimento e as tensões, daí decorrentes, entre os direitos de investidores estrangeiros e os direitos humanos dos cidadãos dos países que recebem os investimentos" (SCHLEMMER-SCHULTE, 2012, p. 419, tradução livre). As sugestões são de duas naturezas: de lege lata e de lege ferenda. As sugestões de lege lata, que importam mais no presente momento, consistem em: (a) harmonizar a proteção dos investimentos e o direito internacional dos direitos humanos com base no princípio da integração sistêmica; (b) reafirmar o caráter jus cogens ou erga omnes dos direitos humanos; (c) considerar a mudança fundamental das circunstâncias nas quais as obrigações foram assumidas; (d) aplicar princípios de direito internacional geral baseados na ideia de cláusulas abusivas.

(a) Inicialmente, reivindica-se a aplicação do artigo 31(3)(c) da Convenção de Viena sobre Direito dos Tratados, conhecido por enunciar o assim chamado princípio da integração sistêmica. É dizer: as normas de direito dos investimentos internacionais devem ser interpretadas levando em conta um escopo normativo ampliado, considerando normas que não pertencem a esse campo específico da normatividade internacional. De acordo com o dispositivo invocado, "serão levados em consideração, juntamente com o contexto[,] (...) quaisquer regras pertinentes de Direito Internacional aplicáveis às relações entre as partes". 
A norma tem a pretensão primeira de possibilitar ao intérprete a utilização do direito costumeiro para complementar a aplicação de regimes jurídicos específicos, mas encontra uma grande limitação nos seus usos pretéritos no âmbito internacional, como se pode deduzir do seguinte extrato da decisão do caso MOX Plant (Irlanda v. Reino Unido - disputa sobre o artigo 9 da Convenção de Proteção do Meio Ambiente Marinho do Nordeste Atlântico), no qual fícou definido que não pode a Convenção de Viena sobre Direito dos Tratados servir para estabelecer a prevalência de um regime jurídico em detrimento de outros: "O objetivo primeiro do emprego de uma linguagem similar é criar parâmetros jurídicos uniformes e consistentes no campo da proteção do meio ambiente marinho, e não criar precedência de um corpo de remédios jurídicos sobre o outro" (ORGANIZAÇÃO DAS NAÇÕES UNIDAS, 2004, p. 100, tradução livre). Ainda assim, o trecho de nenhuma maneira nega a ideia de uniformidade; em vez disso, vem reafirmá-la, estabelecendo como missão do intérprete a conciliação dos procedimentos em matérias de direito internacional abrangidas por mais de um regime.

(b) Além disso, registra-se um apelo ao recorrente argumento de que as normas de direitos humanos comporiam um quadro de normas de seguimento obrigatório pelos Estados e pelos demais atores internacionais, inclusive tribunais arbitrais. De maneira genérica e pouco precisa, Schlemmer-Schulte afirma que

na qualidade de obrigações erga omnes ou de obrigações devidas pela comunidade internacional como um todo, determinadas obrigações de direitos humanos merecem precedência sobre outras obrigações internacionais, como o dever de proteção aos investidores, por conta do caráter de interesse público presente nas normas de direitos humanos (SCHLEMMER-SCHULTE, 2012, p. 420, tradução livre).

A defesa da prevalência de normas de direitos humanos em virtude de ocuparem um status hierárquico superior no sistema de direito internacional adviria, para a autora, da aplicação do artigo 103 da Carta das Nações Unidas, segundo o qual, "no caso de conflito entre as obrigações dos Membros das Nações Unidas, em virtude da presente Carta, e as obrigações resultantes de qualquer outro acordo internacional, prevalecerão as obrigações assumidas em virtude da presente Carta”. Com o passar do tempo, alguns autores passaram a enxergar um efeito amplo desse dispositivo, defendendo a possibilidade de invalidação, em tese, de tratados que se encontrassem em conflito com a Carta da ONU, com base em uma visão desse documento como uma espécie de Constituição internacional (COMISSÃO DE DIREITO INTERNACIONAL, 2006, p. 170, tradução livre). 
A preocupação com a centralidade dos direitos humanos tem sido, de fato, o principal motivo do apelo cada vez mais recorrente a uma constitucionalização de nível internacional, feito mesmo por acadêmicos que não costumavam colocar sob seus holofotes esse campo jurídico. Exemplo disso é recente publicação de Jürgen Habermas sobre o tema, na qual o autor defende que a tendência contemporânea de fragmentação tem conduzido a uma crescente regressão em conquistas democráticas, eufemizada por meio da ênfase corrente, no atual estado de proliferação de organizações internacionais, na ideia de governança global, em detrimento de direitos formalizados à maneira clássica:

O incremento nas funções organizacionais, que se pode perceber no nível supranacional por meio da cooperação entre estados, pode ser descrito como uma tendência rumo à racionalização do exercício do poder político na arena internacional; mas nós não podemos qualificar essa tendência como um processo civilizatório, uma vez que as organizações internacionais somente exercem seus mandatos com base em tratados internacionais, e, portanto, sob a forma de direito, mas ainda não em conformidade com o direito democraticamente formulado - isto é, legitimamente. Governança global é um termo eufemístico para o caráter antidemocrático da institucionalização das relações internacionais que presenciamos até hoje (HABERMAS, 2013, p. 5, tradução livre).

(c) Também se aventou a possibilidade de aplicação da regra de exceção ao princípio elementar do pacta sunt servanda, qual seja, a regra interpretativa segundo a qual a mudança fundamental das circunstâncias originalmente pactuadas poderia gerar o direito à repactuação, conforme já antes referido neste trabalho. Grosso modo, trata-se da aplicação do princípio, bastante frequente na legislação doméstica, do rebus sic stantibus. Schlemmer-Schulte incorpora ao seu argumento o fato de que tanto as disposições do tratado bilateral sobre investimentos ArgentinaEstados Unidos como os Artigos da Comissão de Direito Internacional sobre Responsabilidade dos Estados preveem exceções de emergência, que seriam, para a autora, expressões da regra costumeira do câmbio de circunstâncias.

(d) Por fim, Schlemmer-Schulte aponta que "outro argumento forte que pode inclinar a balança em favor dos direitos humanos pode ser encontrado no conceito de cláusulas contratuais abusivas, acolhido por diversos âmbitos da legislação doméstica" (SCHLEMMER-SCHULTE, 2012, p. 421, tradução livre). Nesse caso, a constante aplicação do princípio no direito interno de diversos países o elevaria ao status de um princípio geral de direito internacional. Subjaz a essa construção a ideia de que são identificáveis regras costumeiras construídas a partir da tradição do direito interno. O relatório da CDI sobre a fragmentação no direito internacional identifica com precisão a busca dessa modalidade argumentativa:

Tais regras e princípios gerais são aplicáveis em função da sua mera "generalidade" e sua validade é baseada em nada mais que o teste denominado por Thomas Franck de "teste do mas é claro" - 
um senso comum mais ou menos instável da comunidade internacional (governos, juízes, acadêmicos). Nenhuma referências especial foi necessária à Corte Permanente de Justiça Internacional, por exemplo, quando no caso Chorzów pontuou que: “...é um princípio do direito internacional, e mesmo um princípio geral de direito, que qualquer violação de um compromisso envolve uma obrigação de reparar". O mesmo se percebe no caso dos diversos princípios identificados pela Corte Internacional de Justiça, como a liberdade de comunicação marítima, "boa fé", "embargo", ex injuria non jus oritur, e assim por diante. Outros exemplos incluem o critério de soberania (Loizidou); o direito da responsabilidade estatal (que influenciou tanto a abordagem das obrigações de direitos humanos como o direito das contramedidas econômicas no âmbito da OMC); o direito das imunidades; o uso da força; o princípio da boa-fé (COMISSÃO DE DIREITO INTERNACIONAL, 2006, p. 235-236, tradução livre).

\subsubsection{A construção da doutrina das dividas odiosas e sua aplicabilidade ao caso argentino.}

Além dos aspectos da construção argumentativa de Sabine Schlemmer-Schulte, acima sintetizados, são possíveis outras abordagens a respeito da resolução de conflitos normativos derivados da crise econômica argentina. Merece especial destaque a aplicação da chamada doutrina das dívidas odiosas, que no caso específico em discussão foi aventada como uma saída possível para a defesa das medidas do governo argentino por Andreas Fischer-Lescano. Para o autor,

o problema da crise de endividamento argentino pode ser compreendido como um exemplo do domínio exercido pelo código econômico na sociedade mundial, o qual manifesta que a prevalência desse código causou danos não somente concernentes à existência de seres humanos passando fome, e cuja autoconstituição como indivíduos se vê atingida, mas também afetou as perspectivas de futuro do sistema político argentino... (FISCHER-LESCANO, 2005, p. 25, tradução livre).

Resgatando exemplos históricos de casos em que a impossibilidade de pagamento levou a reajustes contratuais ${ }^{34}$, Fischer-Lescano reivindica uma apropriação da dogmática jurídica com "consequências mais amplas" que as usuais. Para tanto, apropria-se do conceito de dívida odiosa, cuja história se passa a relatar brevemente para se aferir a sua aplicabilidade ao caso da crise argentina, especialmente no que tange aos debates desenvolvidos no âmbito do Tribunal Constitucional Federal alemão.

Alguns autores ${ }^{35}$ buscam as origens desse debate na década de 1920, quando o publicista russo Alexander Sack publicou o estudo Les effets des transformations des Etats sur leurs dettes publiques et autres obligations financières ${ }^{36}$, no qual defende que nos casos de sucessão de Estado,

\footnotetext{
${ }^{34}$ O autor destaca a remissão da dívida alemã em 1953, os acordos que sucederam à Primeira Guerra Mundial, o Tratado Franco-Austríaco de 1797, o Tratado de Tilsit de 1807 (França e Prússia), entre outros, além de instrumentos específicos de instituições financeiras multilaterais (FMI, Banco Mundial, Clube de Paris, UNCTAD, G8 etc.). Cf. (FISCHER-LESCANO, 2005, p. 26).

${ }^{35}$ Cf. MICHALOWSKI, 2008.

${ }^{36}$ Cf. SACK, 1927.
} 
um novo governo soberano poderia renegar a dívida anterior, por se tratar de uma dívida odiosa. Para Sack, "se um poder despótico contrai uma dívida não para as necessidades e interesses do Estado, mas para fortalecer seu regime despótico, para reprimir a população que luta contra ele, (...) então esta dívida é odiosa", e seu pagamento "não é obrigatório para a nação; é uma dívida de regime, dívida pessoal do poder que a contratou" (SACK, 1927, p. 97).

Assim, em seu formato tradicional, a teoria das dívidas odiosas caracterizou-se por defender a anulabilidade de dívidas públicas quando acumuladas três condições: (i) que tenha sido contraída sem o consentimento da população do país devedor; (ii) que não tenha sido contraída em benefício das pessoas do país; e (iii) que os credores pudessem ter ciência da natureza odiosa da dívida (MICHALOWSKI, 2007, p. 93). Alguns eventos históricos são costumeiramente mencionados para embasar a validade e a aplicabilidade dessa teoria no direito internacional, dentre os quais se destaca a anulação da dívida cubana pelo Tratado de Paris, de 1898, quando os Estados Unidos teriam reconhecido que a dívida herdada do período em que Cuba era colônia espanhola seria odiosa, por ter sido imposta pela Espanha para reprimir o movimento cubano de independência (WEBER, 2003, p. 47). Naquela ocasião, o comissário norte-americano pronunciouse da seguinte forma:

Nenhum ponto de vista permite descrever as dívidas acima mencionadas como dívidas locais de Cuba ou como dívidas contraídas em benefício de Cuba. Em nenhum sentido elas são obrigações corretamente imputáveis a essa ilha. Eles são dívidas criadas pelo governo da Espanha, para seus próprios fins e através dos seus próprios agentes, em cuja criação Cuba não teve voz. Do ponto de vista moral, a proposta de impor essas dívidas a Cuba é igualmente insustentável ... O ônus da chamada 'dívida cubana', imposta ao povo de Cuba sem o seu consentimento e pela força das armas, foi uma das principais injustiças que justificaram a luta de Cuba por sua independência... A dívida foi contratada pela Espanha para fins nacionais, que em alguns casos eram estranhas e em outros realmente adversas ao interesse de Cuba (MICHALOWSKI, 2007, pp. 34-35).

Como afirma Sabine Michalowski, as considerações do comissário norte-americano apresentam poucas contribuições a uma formulação jurídica do conceito de dívida odiosa, atendose mais a aspectos de índole moral. Ademais, os próprios pressupostos para a declaração de uma dívida como odiosa mostram-se frágeis em seu aspecto jurídico, devido à abertura conceitual que proporciona, fazendo com que o tema da legitimidade das dívidas contraídas por regimes autoritários assemelhe-se a diretrizes de soft law. Michalowski aponta as principais deficiências da teoria:

A doutrina das dívidas odiosas é desenhada para encontrar um equilíbrio equitativo entre os interesses das pessoas sob os mandos da ditadura e de uma dívida que não lhes provia benefícios, e mesmo as prejudicava, de um lado, e os interesses dos credores que queriam ser ressarcidos pelos empréstimos que realizaram, de outro. O ponto de partida dessa doutrina é a regra segundo a qual os contratos são vinculantes e precisam ser honrados (pacta sunt servanda); que os direitos 
dos credores deveriam normalmente prevalecer e mesmo permanecer ainda que em caso de sucessão de Estado; e que as pessoas de um país somente podem repudiar dívidas que não lhes trouxeram benefícios se constatadas circunstâncias excepcionais, aferidas pela comunidade internacional. A doutrina, se levada a cabo dessa forma, não questiona a validade geral de empréstimos que foram realizados por regimes ditatoriais (MICHALOWSKI, 2007, p. 64).

Para a autora, mostra-se muito mais significativa uma alteração de foco na doutrina das dívidas odiosas. Seria necessário que ele se deslocasse de uma visão que enfatiza o consentimento e o benefício para o povo para outra em que seja atribuída maior importância às violações de normas imperativas (jus cogens) e de princípios gerais do direito internacional (MICHALOWSKI, 2007, p. 95). Para tanto, parte-se da análise do art. 53 da Convenção de Viena sobre Direito dos Tratados, segundo o qual "é nulo um tratado que, no momento de sua conclusão, conflite com uma norma imperativa de Direito Internacional geral".

O âmbito específico de incidência do jus cogens é bastante restrito, havendo consenso generalizado sobre sua incidência apenas sobre alguns campos específicos, como a ilegalidade das guerras de agressão e dos crimes contra a humanidade, a proibição da tortura e o direito de autodeterminação dos povos (MICHALOWSKI, 2007, p. 73). A solução do problema dessa restrição poderia, então, ser encontrada ao se considerar que há uma ligação direta entre o contrato de empréstimo e uma violação ao jus cogens. Se o ato de endividamento não gera, em si, uma violação do jus cogens, as razões pelas quais ele é promovido podem estar diretamente vinculadas a práticas violadoras, como a realização de torturas ou a prática de outros crimes contra a humanidade resultantes do financiamento de determinados regimes políticos.

Mas não seria apenas sobre o jus cogens que repousaria a possibilidade de contestação de dívidas contraídas por regimes ditatoriais. Também seria possível verificar tal possibilidade por meio da aplicação dos princípios do direito internacional, tais como o direito ao desenvolvimento dos povos (MICHALOWSKI, 2007, p. 89), a vedação da lesão ${ }^{37}$, além da proibição do enriquecimento sem causa e do abuso de direito. Não se poderia estabelecer, a priori, que o princípio do pacta sunt servanda devesse prevalecer sobre o restante do ordenamento jurídico, principalmente em face da constatação de que os tratados se dirigem ao regramento da vida de indivíduos e coletividades por eles afetados.

\footnotetext{
${ }^{37}$ A lesão, instituto clássico do direito civil, é entendida como a situação na qual "uma das partes aproveita-se da situação de debilidade ou de instabilidade da outra para obter uma vantagem econômica importante" (FATTORELLI, 2006, p. 77).
} 
Partindo dessa concepção, tanto Michalowski quanto Fischer-Lescano vislumbraram as ligações entre as obrigações financeiras assumidas pela Argentina e a herança de endividamento provinda da ditadura militar ocorrida naquele país entre 1976 e 1983 (relação esta já referida anteriormente neste trabalho), interpretando em sentido mais amplo a ideia de dívida odiosa, tradicionalmente concebida sob os marcos da sucessão de estado, para compreendê-la como aplicável aos casos de sucessão de regime, quando quer que tenha ocorrido violação a marcos especiais de proteção a determinados direitos, tais como os direitos humanos. É o que se deduz da construção teórica de Fischer-Lescano:

No entanto, no exemplo argentino se trata, justa e principalmente, de uma dívida desse tipo, de uma "dívida de regime". Pois esta problemática começou no ano de 1976, quando teve início a última ditadura militar, um regime político que se caracterizou por ter cometido sistemáticas violações de direitos humanos. Antes dessa data, a Argentina era um país da periferia moderna relativamente rico. Desde então, sua dívida externa começou a incrementar-se, passando de um montante inferior aos 8 bilhões de dólares a um patamar que, no presente, ultrapassa os 160 bilhões de dólares. Seria muito fácil atribuir a causa somente à evasão de capitais das elites sociais. O sistema financeiro internacional é uma maquinaria algo mais complexa (...). Quaisquer que sejam as cotas de causalidade que se queira conferir às medidas de política econômica da Argentina pós-ditatorial, considerando a situação da dívida na atualidade, a causa decisiva da crise da dívida externa, seu ponto de partida e sua condição sine qua non, é o endividamento da Argentina no período militar (FISCHER-LESCANO, 2005, p. 27-28).

Realizando um apelo à necessidade de se estabelecerem hierarquias normativas - as quais, segundo o autor, consistem não em um sistema vertical kelseniano, mas em "strange loops" -, continua ele:

Esta é exatamente a função do art. 53 da Convenção de Viena sobre Direito dos Tratados: a de facilitar uma reticulação retroativa de resoluções com o já resolvido. A que se refere esse já resolvido? (...) a norma que interessa no exemplo argentino não é do tipo que diz: acordos de direito internacional que conduzem a dividas odiosa são nulos. Pelo contrário, uma norma que se veja violada através da dívida odiosa é mais que suficiente. A nulidade do acordo a que se faz referência é consequência do próprio artigo 53 dessa Convenção. Assim, não existe dificuldade em reconhecer que, para justificar uma norma tal - as "dividas odiosas são nulas" -, pode-se prescindir de novas conclusões convencionais, e que, do contrário, é possível por em consideração a validade do direito decorrente do jus cogens; dessa maneira, já não se trata de encontrar provas para uma norma de direito internacional consuetudinário - as "dividas odiosas são nulas" - ou para uma regra determinada pelos princípios gerais de direito, mas de avaliar os direitos fundamentais em colisão, eventualmente também em acumulação. Cabe adicionar que este não é um fenômeno novo; veja-se, por exemplo, a decisão tomada pelo Tribunal Iugoslavo no caso Furudziya, para poder observar essa técnica em sua aplicação (FISCHER-LESCANO, 2005, p. 30-31).

A partir do diagnóstico de que ocorreram graves violações aos direitos humanos associadas à contração de dívidas ditatoriais, seria possível, portanto, enfrentar a crise que se sucedeu - ainda que com um afastamento temporal de vinte anos. Isso seria devido, segundo

Fischer-Lescano, ao fato de que os direitos vinculados ao jus cogens não são prescritíveis, 
constituindo verdadeira lei de ordem pública internacional ${ }^{38}$, com regime próprio de responsabilidades, o qual transferiria aos credores o ônus de se servirem ao abastecimento, à conversão e à novação das dívidas herdadas da ditadura.

Com tudo isso, é possível assegurar que a dívida externa argentina repousa sobre contratos obrigacionais que remontam às dividas odiosas da junta militar, cuja mácula não perdem por ter sido submetida reiteradamente a conversões swap. Para além de como se tenham comportado os governos seguintes, democraticamente eleitos, a obrigação de direito internacional da República Argentina, de restituir os créditos remontáveis à ditadura militar e os custos consecutivos resultantes são nulos, sempre e quando esses créditos tenham sido postos à disposição para o financiamento do conflito armado mencionado, ou para o financiamento dos seus projetos nepotistas. (...) São nulos, independentemente de se tratarem de contratos com outros Estados, com organizações internacionais ou com agentes privados (FISCHER-LESCANO, 2005, p. 32).

Alguns outros estudos abordam o tratamento do problema atual de endividamento a partir de sua perspectiva histórica, apreciando-os sob o regime constitucional da justiça de transição. Tal como os demais autores mencionados neste tópico, eles associam o terror de estado à geração de dívida. Destaca-se, nesse particular, a pesquisa desenvolvida por Juan Pablo Bohoslavsky e Marcelo Torelly (BOHOSLAVSKY; TORELLY, 2012), cuja premissa assim sintetizei em trabalho anterior:

Bohoslavsky e Torelly, com fundamento na teoria da escolha racional, investigaram os procedimentos dos governos autoritários para conquista de apoio público. Concluíram que "existe, essencialmente, um trade off entre lealdade e repressão" sob ditaduras: "Os ditadores procurarão permanecer no poder, assegurando privilégios para as elites e/ou os militares, dispondo de benefícios econômicos ou restringindo liberdades políticas" (LOPES, 2013, p. 19).

A utilização da linguagem dos direitos humanos ou da tese das dívidas odiosas, no entanto, esbarra em grandes dificuldades em nosso sistema de direitos. Em primeiro lugar, seria necessário afastar o regime estipulado nos próprios contratos para que tais normas tivessem prevalência. Em segundo lugar, a afirmação dos tratados internacionais de direitos humanos como normas superiores em matéria de direito internacional implica uma utilização do mesmo aparato conceitual contra o qual se insurge essa linguagem. É dizer: ao vaticinar a necessidade absoluta de aplicação dos direitos humanos como regime específico e autônomo contra a regulação financeira, abre-se espaço para uma disputa sem verdades objetivas e predefinidas, que, no fim do processo, poderá

\footnotetext{
${ }^{38}$ Fischer-Lescano cita Walter Kälin para explicitar o significado do termo: "Este termo - ordem pública-compreende aqueles valores fundamentais da própria ordem jurídica nacional, os quais evitam, como meio de proteção do próprio ordenamento jurídico (e, assim, da própria soberania), a aplicação da ordem jurídica alienígena (...). De maneira oposta, o conceito de 'ordem pública internacional' define aquelas máximas de direito internacional com as quais - com vistas a interceptar uma ordem jurídica alheia infratora do direito internacional - o direito estrangeiro deve concordar em seu conteúdo, para que se possa fazer aplicável” (KÄLIN apud FISCHER-LESCANO, 2005, p. 32).
} 
legitimar e consolidar as posições dominantes mediante a ressignificação de direitos como a propriedade e a liberdade contratual.

Assim, o resultado de uma tal operação, caso prescinda do cuidado de precisar as relações políticas em jogo, pode acabar sendo o reafirmar os mitos fundantes do rule of law, sistematicamente utilizados para promover, desde pelo menos o século XVIII, aquilo que Ugo Mattei e Laura Nader denominam de pilhagem, em um sistema-mundo ainda maculado pelas marcas do imperialismo (MATTEI; NADER, 2008). O ideal de constitucionalização, por outro lado, continua a se arvorar no mito do poder constituinte, aquele que tudo pode, mas, na prática, somente se tem exercido, local ou globalmente, por meio de uma representação política duvidosa, que contribui para a perpetuação conservadora das estruturas sociais. Como afirma James Tully:

Em terceiro lugar, não é possível compreender o campo das relações interativas entre formas constitucionais e poderes constituintes sem enxergar um terceiro ator internamente relacionado com aqueles outros dois. Como Loughlin e Walker apontam, o constitucionalismo moderno não derivou historicamente do exercício dos poderes constituintes dos povos soberanos ou das multidões, isoladamente. Se houvesse derivado, nós não teríamos a relação antagônica entre os dois. Ainda, como mostrou Quentin Skinner, as constituições modernas são também produto da "soberania" no sentido tradicional de elemento regulador: o monarca, o imperador, a Coroa, a aristocracia, a classe dominante, a elite ou, mais comumente, o Estado soberano, em uma relação agonística com as pessoas. Essa é a forma do poder "constituinte" que é tradicionalmente mencionado como conformador das ordens política e jurídica no Ocidente desde o direito romano (TULLY, 2008, p. 471).

A formulação clássica desse poder constituinte, aliás, escapa à valoração tão necessária a uma afirmação do discurso dos direitos humanos. É que, desde suas origens hobbesianas, o conceito moderno de lei fundamental - que não significa precisamente o desenvolvimento posterior da Constituição, mas dela é discursivamente aproximado - sempre significou uma fórmula abstrata e genérica, "uma exigência normativa unitária dirigida à preservação da posição de poder do soberano" (FERREIRA, 2013, p. 438).

A constituição, no âmbito local ou em dimensão global, denomina não mais que aquilo que Giorgio Agamben, ancorado em categorias desenvolvidas por Michel Foucault e G. W. Hegel, denomina de dispositivo. Partindo de uma perspectiva ontológica da política, Agamben identifica o dispositivo como "aquilo que e por meio do qual se realiza uma pura atividade de governo sem nenhum fundamento no ser" (AGAMBEN, 2013, p. 38), o que implica processos de despolitização caracterizados pela dessubjetivação mediadora do "eclipse da política, que pressupunha sujeitos e identidades reais (o movimento operário, a burguesia etc.), e o triunfo da oikonomia, isto é, de uma pura atividade de governo que visa somente à sua própria reprodução" (AGAMBEN, 2013, p. 48-49). 
O apelo à emergência de uma constituição global sob os parâmetros de direitos humanos já acentuado é, no final das contas, um discurso dispositivo, pois, como bem pontua Michel Foucault, "se confere, no início, uma multiplicidade de poderes que não são poderes no sentido político do termo, mas são capacidades, possibilidades, potências, e (...) ela só pode constituí-los como poderes, no sentido político do termo, com a condição de ter, entrementes, estabelecido (...) um momento de unidade fundamental e fundadora, que é a unidade do poder" (FOUCAULT, 2005, p. 49-50). Isso faz com que a perspectiva relacional do poder seja velada pelo discurso recorrente da unidade fundante. Assim, talvez interesse mais, no âmbito das relações dos sujeitos envolvidos nas disputas de interesse entre matérias tradicionalmente ligadas aos direitos humanos e aquelas vinculadas ao direito internacional dos investimentos, compreender e desvelar os usos das técnicas clássicas de apreensão do direito.

Aqui, não parece haver dúvidas de que o apelo a qualquer discurso superior, a uma metaordem normativa como modo de resolução dos instrumentos propriamente políticos de dominação, implica simplesmente uma reciclagem dos dispositivos vigentes, incapaz que é de revolver as estruturas que sustentam o aparato de poder.

\subsection{O império contra-ataca - o resgate da política agonística para além das disputas epistêmicas.}

O caso da crise argentina e sua discussão nos distintos foros constitucionais, bem como as críticas que lhe sucederam, vindas dos defensores da aplicação do regime específico das finanças internacionais ou vindas dos defensores da aplicação soberana dos direitos humanos, é exemplar para acentuar os dilemas advindos da fragmentação. Grande parte deles, como bem apontam Koskenniemi e Leino, advém de uma "preocupação com a 'perda de controle' ou com a ausência de um 'plano abrangente"” (KOSKENNIEMI; LEINO, 2002, p. 575, tradução livre) para os setores específicos do direito estabelecerem suas técnicas próprias de decisão, todas recorrentes a uma unidade que implica, ao fim e ao cabo, a prevalência de interesses pontuais em torno dos quais se desenvolveu todo um corpo epistêmico.

Cada corpo epistêmico pretende promover uma pretensa universalidade de seus campos particulares, utilizada para mitigar ou ocultar, detrás de falsos consensos, as reais disputas de poder existentes, recorrendo a uma ferramenta já há muito tempo utilizada pela construção teórica da democracia liberal. Como diagnosticou, ao final do século passado, Chantal Mouffe, à direita e à 
esquerda, "a democracia liberal parece ser reconhecida como a única forma legítima de governo" (MOUFFE, 2000, p. 80), cuja pretensão principal consiste em, atendidos procedimentos formais de deliberação, "atingir formas de acordo que satisfaçam, ao mesmo tempo, a racionalidade (compreendida como defesa dos direitos liberais) e a legitimidade democrática (representada pela soberania popular” (MOUFFE, 2000, p. 83). Essa forma de proceder específica, que ganhou contornos de definitividade com o acabamento que lhe deu o constitucionalismo ocidental, foi mais recentemente encorpada e reforçada, embora não se neguem as tensões por isso ocasionadas, pela emergência de um mindset gerencial, que, como visto, buscou tecnificar as soluções jurídicas, transmudando interesses hegemônicos em posições de um irrefutável planejamento econômico.

A história do rule of law, como bem demonstram as lutas coloniais, é uma história de opressão, promovida especialmente por meio da proteção aos direitos de propriedade. $\mathrm{O}$ descompromisso histórico do rule of law com a realização material dos pleitos reivindicados pelos defensores de medidas de exceção aos direitos de propriedade - e não ao direito como um todo, em um sentido schmittiano - é, aliás, bem exposto por Hans Kelsen, para quem

\begin{abstract}
A liberdade negativa, essencial à democracia moderna, existe na proibição constitucional de qualquer ato legislativo, administrativo ou judiciário que restrinja o exercício da religião, ciência ou arte, a expressão da opinião na imprensa ou qualquer outro veículo, a associação com finalidade jurídica e coisas semelhantes. As liberdades ou direitos humanos que uma constituição deve garantir para ser considerada democrática são reflexos de uma certa limitação do poder do governo. Mas, como foi mostrado, a garantia constitucional dessas liberdades intelectuais não garante nenhuma liberdade na satisfação das necessidades intelectuais através dos meios econômicos necessários. Talvez seja correto enfatizar que, por essa razão, as liberdades humanas garantidas por uma constituição democrática não passam de liberdades "formais" ou "jurídicas" (KELSEN, 2000, p. 278).
\end{abstract}

Nas disputas sobre questões de índole econômica, qualquer análise deve ter em mente as aceleradas mudanças que ocorrem nesse subsistema social e seu forte apelo técnico na modernidade tardia. A dinâmica própria da economia, cujo ritmo é imposto pelos novos processos de acumulação capitalista, tem feito com que cada vez mais os subsistemas especializados do direito operem por uma lógica de apelo autônomo, cujas fontes transcendem os órgãos legislativos clássicos, mas são circunscritas a domínios muito restritos do conhecimento (TEUBNER, 2003, p. 24-25). Isso, obviamente, preocupa em termos de acesso democrático a campos jurídicos com importante repercussão social (veja-se, por exemplo, o impacto gerado pela crise econômica argentina), gerando apelos a reformulações nos dispositivos técnicos de que dispõe o direito com vistas a atribuir-lhe fins que se poderiam denominar mais justos. 
Entretanto, diante da consciência de que esses dispositivos operam por meio das lógicas da docilização e da dessubjetivação, que em última instância implicam despolitização, qualquer apelo teórico a uma repolitização das decisões econômicas exige novas construções, que escapem à mera reprodução das técnicas clássicas de interpretação de direitos, inclusive já apropriadas para finalidades do sistema econômico vigente (vide, por exemplo, a apropriação do discurso dos direitos humanos pela OMC, apontada no relatório da Comissão de Direito Internacional sobre fragmentação). É o que esboça Teubner, embora ainda bastante confiante em uma forma jurídica de viés universalizável:

A relativa distância à política internacional e ao direito internacional não preservará o "direito
mundial sem Estado" de uma repolitização. Muito pelo contrário: justamente a reconstrução de
(trans)ações sociais e econômicas como atos jurídicos globais solapa o caráter apolítico do direito
global e fornece dessarte o fundamento da sua repolitização. Ela, porém, ocorrerá previsivelmente
sob novas formas, pouco conhecidas até agora. Suspeito que o direito mundial não será
repolitizado por instituições políticas tradicionais, e.g. de natureza por assim dizer parlamentar,
mas justamente pela via daqueles processos nos quais o direito mundial se "acopla
estruturalmente" a discursos altamente especializados, isolados (TEUBNER, 2003, p. 11).

O medo gerado em torno da ausência de unidade leva à percepção de que "a fragmentação é uma retórica poderosa para contestar o projeto alheio" (MARTINEAU, 2009, p. 3), com base na ilustração do contexto jurídico e social contemporâneo como uma colcha de retalhos, esboço de uma realidade anárquica e de uma desordem global em proporções indescritíveis. Como afirma Martineau "invocar a fragmentação é evocar a imagem de uma explosão caótica. Como performativos, essas referências despertam uma sensibilidade particular - isto é, um medo da anarquia, um sentimento de falta de direção, um receio sobre o fim de uma 'ordem' internacional" (MARTINEAU, 2009, p. 4-5).

Nesse particular, pode ser de especial interesse aquilo que Agamben denomina de "profanação dos dispositivos - isto é, [a] restituição ao uso comum daquilo que foi capturado e separado nesses" (AGAMBEN, 2013, p. 51), oportuna que pode ser para uma adequação do discurso político às técnicas mais modernas de estabelecimento das formas de dominação. A globalização econômica, afinal, ainda que pautada por parâmetros jurídicos estabilizados por procedimentos específicos de criação normativa, deixa caladas vozes diversas, reproduzindo opressões que não se remediam pela procedimentalização.

Assim, em lugar de disputar o uso do direito para fins melhores, pode ser o caso de apostar no reforço da ação política em nível global, seja em busca de novas compreensões do significado 
do próprio direito, seja para que venham à tona outras expressões das subjetividades globais, ainda não conhecidas.

Antes disso, porém, é necessário visualizar a fragmentação não como uma "descrição inocente" dos processos globais em andamento, mas como uma expressão de enormes disputas de poder no interior do próprio direito, cujas premissas “explodem o edifício do direito (...) e limpam o terreno para uma proposta de reforma. Trata-se, ao mesmo tempo, de um conceito estético e de um projeto político" (MARTINEAU, 2009, p. 28). O propósito do debate sobre a fragmentação, nesse sentido, impõe-se menos como um diagnóstico - tão-somente - da existência e do potencial de normatividade decorrente da multiplicação de distintos regimes jurídicos especializados e mais como um elemento indiciário da perspectiva relacional de uma real e efetiva disputa sobre o regime jurídico aplicável ao problema do endividamento público argentino.

Para a adequada percepção do movimento que se percebe ao se apreciar a questão, é imprescindível notar que a regulação dos investimentos de cidadãos e empresas estrangeiros em ativos nacionais usualmente é realizada mediante tratados bilaterais de investimentos capazes de assegurar alguma garantia aos investidores. Assim, por exemplo, as relações comerciais entre investidores norte-americanos e o Estado Argentino - e vice-versa - são regidas pelo Tratado Bilateral sobre a Promoção e a Proteção Recíproca de Investimentos, assinado pelos dois países em $1992^{39}$. Do mesmo modo, também os credores alemães se encontram protegidos pelo Tratado entre a República Federal da Alemanha e a República Argentina sobre Promoção e Proteção Recíproca de Investimentos ${ }^{40}$, datado de 1991.

A leitura de ambos os tratados permite compreender que, em seus propósitos enunciados, consistem em instrumentos normativos que preveem certa igualdade formal em matéria de investimentos. Indícios dessa constatação são verificados em diversos dispositivos, como os que se destacam a seguir:

Artigo II, 1 (Estados Unidos-Argentina): “Cada parte permitirá e tratará os investimentos e suas atividades afins de maneira não menos favorável que aquela outorgada em situações similares aos investimentos ou atividades afins de seus próprios nacionais ou empresas, ou aos de nacionais ou empresas de terceiros países, seja qual for o tratamento mais favorável, sem prejuízo do direito de cada parte de fazer ou manter exceções que correspondam a alguns dos setores ou das matérias que figuram no Protocolo anexo ao presente tratado" (tradução livre).

\footnotetext{
${ }^{39}$ Disponível em http://www.wipo.int/wipolex/es/details.jsp?id=12165.

${ }^{40}$ Disponível em http://www.wipo.int/wipolex/es/details.jsp?id=12132.
} 
Artigo 2, 1 (Alemanha-Argentina): "Cada uma das partes contratantes promoverá, dentro do seu território, os investimentos dos nacionais ou das empresas da outra parte contratante e as admitirá em conformidade com suas leis e suas regulamentações. Em todo caso, tratará os investimentos justa e equitativamente" (tradução livre).

No entanto, a horizontalidade que permeia os textos dos tratados, resultantes da representação legítima de ambos os Estados que os assinaram, não tardou a ser rompida em matéria de endividamento público. Como demonstrado no item 2.3, os decretos de emissão de dívida argentina expressamente renunciavam à oposição da imunidade soberana nas disputas relativas a tal modalidade de investimentos e à possibilidade de eleição de foro pelo país devedor.

A escolha da legislação aplicável e do juízo competente para dirimir questões sobre os investimentos estrangeiros na Argentina passou a depender da opção do governo local a respeito de qual corpo de investidores se objetivava atrair. A pesquisa dos decretos - atos, portanto, insuscetíveis de controle das representações legislativas - que, durante a década de 1990, possibilitaram a emissão de diversas modalidades de títulos da dívida pública indica justamente que, para viabilizar o financiamento no Estado nos mercados internacionais, tornou-se constante a abdicação da condição de exercício da soberania consagrada pela forma estatal moderna - qual seja, a equiparação de forças dos distintos poderes soberanos sobre os seus próprios territórios e suas próprias jurisdições.

No quadro a seguir, há uma amostra dos documentos de expedição de dívida da Argentina durante os anos que precederam a crise de 2001 (com destaques atuais):

\begin{tabular}{|c|c|c|}
\hline Decreto & Títulos emitidos & Cláusula de renúncia \\
\hline $2455 / 1993$ & $\begin{array}{l}\text { Bonos externos globales } \\
\text { de la República Argentina }\end{array}$ & $\begin{array}{l}\text { Art. } 3^{\circ} \text { - Autorízase la inclusión en las condiciones de } \\
\text { emisión de los Bonos, de cláusulas que establezcan la } \\
\text { prórroga de jurisdicción a favor de los tribunales } \\
\text { ubicados en la ciudad de New York, ESTADOS } \\
\text { UNIDOS DE AMERICA; y la renuncia a oponer la } \\
\text { defensa de inmunidad soberana, debiendo } \\
\text { preservarse la inembargabilidad con respecto a: } \\
\text { a) Los activos que constituyen reservas de libre } \\
\text { disponibilidad, dentro del marco de la Ley de } \\
\text { Convertibilidad, cuyo monto, composición e inversión } \\
\text { se reflejen en el Balance General y estado contable del } \\
\text { BANCO CENTRAL DE LA REPUBLICA } \\
\text { ARGENTINA elaborado de conformidad con el } \\
\text { artículo } 5^{\circ} \text { de la Ley } N^{\circ} 23.982 \text {. }\end{array}$ \\
\hline
\end{tabular}




\begin{tabular}{|c|c|c|}
\hline & & $\begin{array}{l}\text { b) Los bienes del dominio público ubicados en el } \\
\text { territorio de la REPUBLICA ARGENTINA o bienes } \\
\text { que le pertenezcan a la REPUBLICA ARGENTINA y } \\
\text { que estén ubicados en su territorio y estén destinados a } \\
\text { los fines de un servicio público esencial. }\end{array}$ \\
\hline $1386 / 1994$ & Todos & $\begin{array}{l}\text { Artículo } 1^{\circ} \text { - Autorízase, en los contratos que suscriba } \\
\text { la REPUBLICA ARGENTINA por operaciones } \\
\text { definidas por el artículo } 12 \text { de la Ley No } 24.307 \text {, la } \\
\text { inclusión de cláusulas que establezcan la prórroga de } \\
\text { jurisdicción a favor de los tribunales estaduales y } \\
\text { federales de la ciudad de NUEVA YORK, ESTADOS } \\
\text { UNIDOS DE AMERICA, y la renuncia a oponer la } \\
\text { defensa de la inmunidad soberana, debiendo } \\
\text { preservarse la inembargabilidad con respecto a: } \\
\text { a) Los activos que constituyen reservas de libre } \\
\text { disponibilidad, dentro del marco de la Ley de } \\
\text { Convertibilidad, cuyo monto, composición e inversión } \\
\text { se refleja en el Balance General y estado contable del } \\
\text { BANCO CENTRAL DE LA REPUBLICA } \\
\text { ARGENTINA, elaborado de conformidad con el } \\
\text { artículo } 5^{\circ} \text { de la Ley N } 23.928 \text {. } \\
\text { b) Los bienes del dominio público ubicados en el } \\
\text { territorio de la REPUBLICA ARGENTINA o bienes } \\
\text { que le pertenezcan a la misma y que están ubicados en } \\
\text { su territorio y estén destinados a los fines de un servicio } \\
\text { público esencial. }\end{array}$ \\
\hline 709/1995 & $\begin{array}{l}\text { Letras externas a mediano } \\
\text { plazo en marcos alemanes }\end{array}$ & $\begin{array}{l}\text { Art. } 3^{\circ}-\text { Autorízase la inclusión, en las operaciones } \\
\text { referidas en el artículo } 1^{\circ} \text {, de cláusulas que establezcan } \\
\text { la prórroga de jurisdicción a favor de los tribunales } \\
\text { ubicados en la Ciudad de FRANCFORT DEL MENO, } \\
\text { REPUBLICA FEDERAL DE ALEMANIA, } \\
\text { pudiéndose extender la prórroga de jurisdicción a los } \\
\text { tribunales estaduales y federales ubicados en NUEVA } \\
\text { YORK, ESTADOS UNIDOS DE AMERICA. } \\
\text { Asimismo se autoriza a aceptar la renuncia a oponer la } \\
\text { defensa de la inmunidad soberana, en la documentación } \\
\text { que suscriba el MINISTERIO DE ECONOMIA Y } \\
\text { OBRAS Y SERVICIOS PUBLICOS por las } \\
\text { operaciones financieras aprobadas por el artículo } 1^{\circ} \text { del } \\
\text { presente Decreto. }\end{array}$ \\
\hline
\end{tabular}




\begin{tabular}{|c|c|c|}
\hline $90 / 1996$ & $\begin{array}{l}\text { Letras externas a mediano } \\
\text { plazo en marcos alemanes }\end{array}$ & $\begin{array}{l}\text { Art. } 3^{\circ} \text { - Autorízase la inclusión, en las operaciones } \\
\text { referidas en el artículo } 1 \text {, de cláusulas que establezcan } \\
\text { la prórroga de jurisdicción a favor de los tribunales } \\
\text { ubicados en la Ciudad de FRANCFORT DEL MENO, } \\
\text { REPUBLICA FEDERAL DE ALEMANIA, } \\
\text { pudiéndose extender la prórroga de jurisdicción a los } \\
\text { tribunales estaduales y federales ubicados en NUEVA } \\
\text { YORK, ESTADOS UNIDOS DE AMERICA. } \\
\text { Asimismo se autoriza a aceptar la renuncia a oponer } \\
\text { la defensa de la inmunidad soberana, en la } \\
\text { documentación que suscriba el MINISTERIO DE } \\
\text { ECONOMIA Y OBRAS Y SERVICIOS PUBLICOS } \\
\text { por las operaciones financieras aprobadas por el artículo } \\
1 \text { del presente Decreto. }\end{array}$ \\
\hline $341 / 1996$ & $\begin{array}{l}\text { Letras externas a mediano } \\
\text { plazo en marcos alemanes }\end{array}$ & 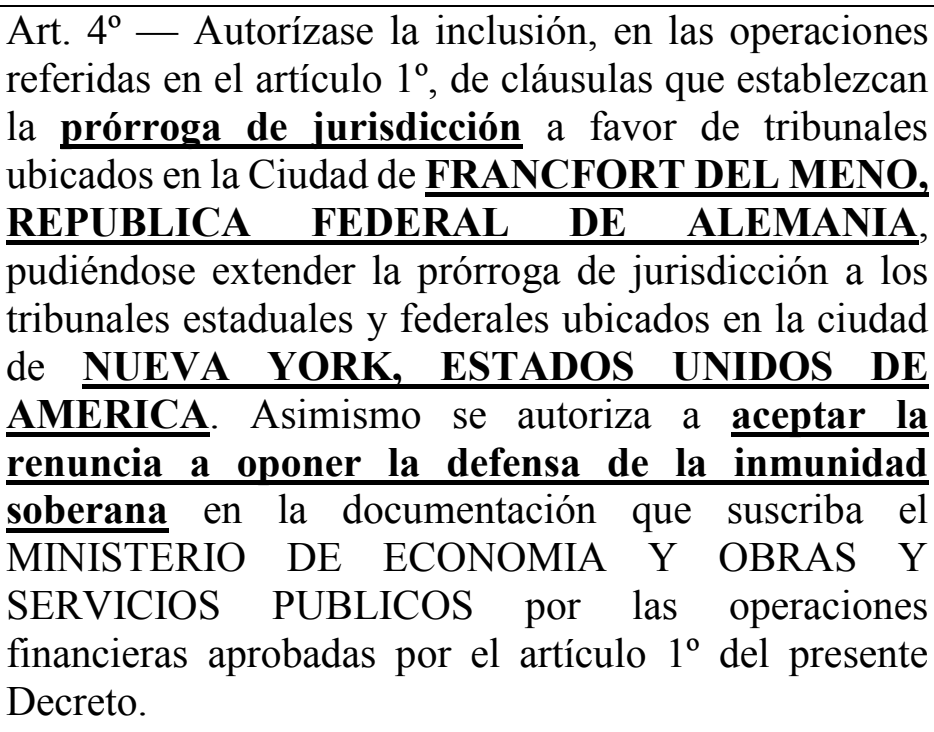 \\
\hline $518 / 1996$ & $\begin{array}{l}\text { Bonos de la República } \\
\text { Argentina en marcos } \\
\text { alemanes }\end{array}$ & $\begin{array}{l}\text { Art. } 4^{\circ} \text { - Autorízase la inclusión, en las operaciones } \\
\text { referidas en los artículos } 1 \text { y } 2 \text {, de cláusulas que } \\
\text { establezcan la prórroga de jurisdicción a favor de los } \\
\text { tribunales ubicados en la Ciudad de FRANCFORT } \\
\text { DEL MENO, REPUBLICA FEDERAL DE } \\
\text { ALEMANIA, pudiéndose extender la prórroga de } \\
\text { jurisdicción a los tribunales estaduales y federales } \\
\text { ubicados en la ciudad de NUEVA YORK, ESTADOS } \\
\text { UNIDOS DE AMERICA. Asimismo se autoriza a } \\
\text { aceptar la renuncia a oponer la defensa de la inmunidad } \\
\text { soberana en la documentación que suscriba el } \\
\text { MINISTERIO DE ECONOMIA Y OBRAS Y } \\
\text { SERVICIOS PUBLICOS por las operaciones } \\
\text { financieras aprobadas por los artículos } 1 \text { y } 2 \text { del presente } \\
\text { Decreto. }\end{array}$ \\
\hline
\end{tabular}




\begin{tabular}{|c|c|c|}
\hline $119 / 1999$ & Todos & $\begin{array}{l}\text { Artículo } 1^{\circ}-\text { Autorízase al MINISTERIO DE } \\
\text { ECONOMIA, a través de la SECRETARIA DE } \\
\text { HACIENDA conjuntamente con la SECRETARIA DE } \\
\text { FINANZAS, a incluir en los contratos por las } \\
\text { operaciones de crédito público correspondientes a la } \\
\text { Administración Central, por un monto equivalente de } \\
\text { hasta VALOR NOMINAL EUROS QUINCE MIL } \\
\text { MILLONES (V.N. EUROS 15.000.000) cláusulas que } \\
\text { establezcan la prórroga de jurisdicción a favor de los } \\
\text { tribunales de la ciudad de LONDRES, REINO } \\
\text { UNIDO DE GRAN BRETANA E IRLANDA DEL } \\
\text { NORTE, a los tribunales ubicados en la ciudad de } \\
\text { FRANCFORT DEL MENO, REPUBLICA } \\
\text { FEDERAL DE ALEMANIA, a los tribunales } \\
\text { ubicados en la ciudad de MADRID, REINO DE } \\
\text { ESPANA, a los tribunales ordinarios ubicados en la } \\
\text { ciudad de GINEBRA, CONFEDERACION SUIZA y } \\
\text { en caso de apelación en los tribunales federales } \\
\text { ubicados en la ciudad de } \underline{\text { LASSANA, }} \\
\text { CONFEDERACION SUIZA, a los tribunales } \\
\text { federales ubicados en la ciudad de MILAN, } \\
\text { REPUBLICA ITALIANA, extendiéndose todas las } \\
\text { anteriores a los tribunales estaduales y federales } \\
\text { ubicados en la ciudad de NUEVA YORK, ESTADOS } \\
\text { UNIDOS DE AMERICA, para las operaciones en } \\
\text { EURO, FRANCOS SUIZOS, y las monedas de los } \\
\text { países signatarios del TRATADO DE } \\
\text { MAASTRICHT". } \\
\text { Asimismo autorízase a aceptar la renuncia a oponer la } \\
\text { defensa de la inmunidad soberana en la } \\
\text { documentación que suscriba el MINISTERIO DE } \\
\text { ECONOMIA, a través de la SECRETARIA DE } \\
\text { HACIENDA conjuntamente con la SECRETARIA DE } \\
\text { FINANZAS, por las operaciones de crédito público } \\
\text { descriptas en el párrafo anterior del presente artículo. }\end{array}$ \\
\hline $1123 / 2000$ & Todos & $\begin{array}{l}\text { ARTICULO } 1^{\circ} . \text { - Autorízase, en los contratos que } \\
\text { suscriba la REPUBLICA ARGENTINA por } \\
\text { operaciones definidas en el párrafo primero del artículo } \\
42 \text { de la Ley } \mathrm{N}^{\circ} 11.672 \text { Complementaria Permanente de } \\
\text { Presupuesto (t.o. 1999), la inclusión de cláusulas que } \\
\text { establezcan la prórroga de jurisdicción a favor de los } \\
\text { tribunales estaduales y federales de la ciudad de } \\
\text { NUEVA YORK, ESTADOS UNIDOS DE }\end{array}$ \\
\hline
\end{tabular}




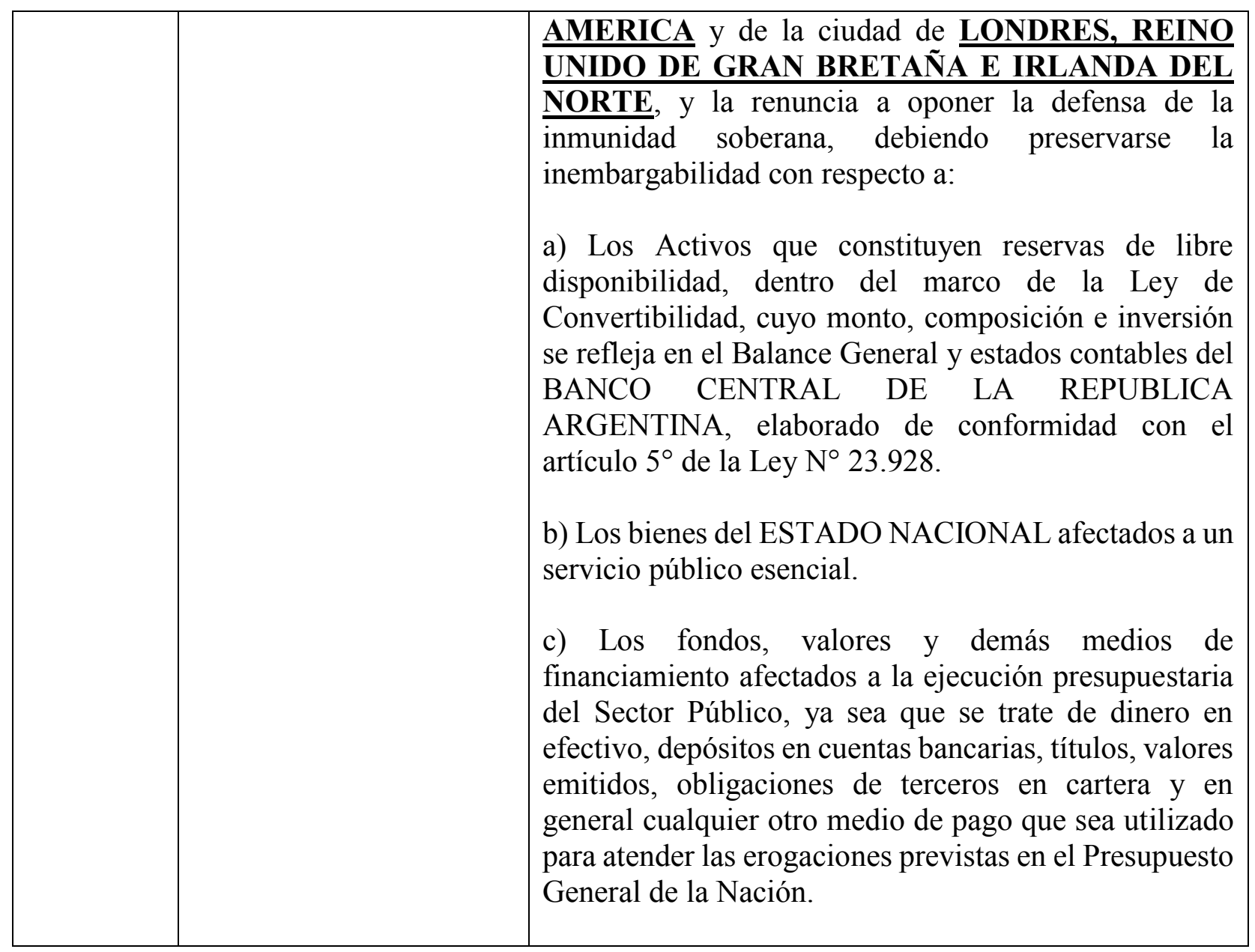

Como é possível verificar nos textos dos decretos por meio dos quais o governo argentino autorizou o lançamento em mercado de títulos da dívida pública daquele país, com o passar do tempo, tornou-se mandatório incluir-se cláusula que autoriza - e, na prática, isso se efetivamente se impunha - a renúncia da Argentina à alegação de imunidade soberana na execução das obrigações, ao mesmo tempo em que se concedia às cortes dos países de onde provinham os seus credores - e consequentemente à legislação desses mesmos países - a autoridade para decidir sobre a validade das normas.

Na prática, operava-se uma verdadeira substituição dos mecanismos bilaterais horizontais fundados no princípio par in parem non habet imperium. Em seu lugar, o que se verifica é a prevalência do direito interno do país de onde provinha o credor, de modo que a existência e a sustentabilidade de uma dívida soberana passam a ser condicionadas, de um lado - e paradoxalmente -, à abdicação da soberania e, de outro, à inaplicabilidade dos mecanismos horizontais e igualitários de conformação do direito. 
Essas duas condições são dois lados de uma mesma moeda. Afinal, não é possível haver horizontalidade se há apenas um lado capaz de fazer impor sua ordem, estendendo-a às obrigações assumidas por outro soberano. É verdade que o governo argentino continuou a expedir ordens que regulavam sua economia interna. No entanto, essas regulações não poderiam extrapolar os interesses de quem residia em outro Estado, economicamente superior e capaz de operar o direito de modo a favorecer os seus próprios interesses.

Aqui, o que se tem é uma configuração próxima àquela que, no medievo, caracterizou a vassalagem a que se submetiam senhores menos poderosos que os suseranos. Na relação estabelecida entre Estados Unidos e Argentina, ou entre Alemanha e Argentina, não há, de fato, dois soberanos em posição de igualdade que firmaram instrumentos aplicáveis de modo equânime entre si. O que de fato se diagnostica é um Estado (Argentina) carente de financiamento externo que se submete, por não conseguir tomar as rédeas da própria economia, às condições, às regulações e à força jurídica de Estados outros (especialmente Estados Unidos e Alemanha) que operam como verdadeiras correias de transmissão dos interesses dos operadores do capitalismo financeiro transnacional.

Com isso, rompe-se com a ideia de um direito internacional dos iguais e instaura-se todo um sistema de endividamento soberano que, na verdade, fundamenta-se no fim da soberania - ou, ao menos, no fim da soberania dos países devedores. A dívida argentina, afinal, deixou de ser constituída pelo direito argentino ou pelo direito internacional dos investimentos e passou a ser constituída, regida e executada pelas normas obrigacionais de países como Estados Unidos e Alemanha.

Diante de um tal contexto, aparece, a toda evidência, a questão: pode um governo abrir mão da própria soberania?

De imediato, uma constatação se impõe: a Argentina dificilmente conseguiria inserção nos mercados internacionais sem o fornecimento da garantia de que abriria mão da aplicação de suas próprias leis e do seu próprio juízo nas controvérsias sobre endividamento público. A justificativa reconhecida pelo próprio Estado Argentino para a renúncia da soberania não era inovatória. Ela já se verificava na década de 1970, quando se começou a lançar mão da mencionada estratégia a fim de se facilitar a captação de crédito externo no contexto de forte financeirização da economia a que já se fez referência no Capítulo 3. Não por acaso, em 1973 - ano de acentuada 
crise decorrente do fim da paridade dólar-ouro, por ocasião da aprovação do Orçamento do país, foi introduzida modificação legislativa que preconizava:

Ao Poder Executivo é facultado, a fim de dar a garantia da Nação, com caráter acessório ou principal, a obrigações que, com as finalidades e sob os requisitos mencionados, assumam entidades públicas ou privadas, submeter eventuais controvérsias com pessoas estrangeiras a juízes de outras jurisdições, tribunais arbitrais com dirimente imparcialmente designado ou à Corte Internacional de Justiça de Haia. (tradução livre) ${ }^{41}$

A escusa oficial para fazê-lo era justamente a facilidade maior na obtenção de crédito, que justificaria inclusive o descumprimento do preceito contido na Constituição da Argentina. O então $\begin{array}{llllll}\text { art.100 daquela norma } & - & \text { atualmente } & \text { art. } & 116^{42}\end{array}$ (http://infoleg.mecon.gov.ar/infolegInternet/anexos/0-4999/804/norma.htm) - determina que devem ser submetidos à jurisdição da Corte Suprema e dos tribunais nacionais inferiores todos os casos que versem sobre "assuntos em que a Nação seja parte”. No entanto, o governo, a partir dos anos 1970, passou a adotar a cláusula de prórroga de jurisdicción para favorecer a necessária “operatividade na captação do crédito externo” (SAMTLEBEN, 1989, p. 252).

A declaração é significativa. Como já visto anteriormente, tratava-se de um período com crédito abundante e, ao mesmo tempo, de um contexto carente de transparência na própria geração de dívida pelos países latinoamericanos. A conjunção desses fatores alçou o endividamento público à condição de um elemento essencial à determinação das relações econômicas contemporâneas, porquanto seguida da conversão de dívidas governamentais em um montante nunca antes visto. Não há dúvidas de que, nesse contexto, há sinais evidentes de uma governança neoliberal que, à luz do que já se expôs, conjuga uma perspectiva moral do crédito com uma racionalidade técnica que termina por afastar, em grande medida, a aplicação do conceito de soberania em proteção aos países devedores.

O que a análise dos decretos de emissão de dívida evidencia, no entanto, vai além disso. Ela mostra que o regime de direito aplicável aos contratos de endividamento opera uma verdadeira substituição da relação de igualdade soberana entre os países por uma relação de suserania e vassalagem que, diga-se de passagem, é imprescindível à manutenção dos mecanismos globais de reprodução do capital financeiro.

A gestão jurídica desses contratos operacionaliza a "conversão da forma autonomizada do capital a juros ou capital portador de juros" (CARCANHOLO; NAKATANI, 1999), fazendo-o

\footnotetext{
${ }^{41}$ Disponível em: http://www.infoleg.gov.ar/infolegInternet/anexos/170000-174999/174047/norma.htm.

42 Disponível em: http://infoleg.mecon.gov.ar/infolegInternet/anexos/0-4999/804/norma.htm.
} 
ultrapassar os limites do indispensável para a sustentação do sistema produtivo e viabilizando a conformação de um sistema global de gestão do endividamento dos países periféricos que transmuta sua própria soberania na submissão moral destes aos sistemas jurídicos - e, portanto, ao domínio econômico - das economias centrais.

Tal movimento foi percebido no estudo antropológico de David Graeber, que localizou os elementos da nova gestão do endividamento após 1971, com o fim do padrão dólar-ouro. A adoção do dólar como moeda de conversão universal fez com que o Federal Reserve Bank (FED) norteamericano adquirisse um poder antes restrito: é o FED que emite a moeda que, a partir de então, passa a servir de parâmetro para as economias nacionais de todo o mundo. Ao mesmo tempo, imperioso recordar que o FED é composto por representantes dos maiores bancos dos Estados Unidos - agentes privados, portanto - escolhidos pelo Presidente daquele país. A gestão do dinheiro nos Estados Unidos, portanto, pertence aos controladores do sistema privado de crédito (GRAEBER, 2011).

Assim, sempre que o governo central dos Estados Unidos necessita de injeção monetária, o FED emite moeda e constitui uma espécie de empréstimo ao governo, que, por sua vez, emite títulos da dívida pública que passam a circular no sistema financeiro, mediante a intermediação bancária - dos mesmos bancos que emitem a moeda-parâmetro de conversibilidade do sistema financeiro global e, assim, alavancam as vantagens econômicas dos Estados Unidos em relação ao restante dos países.

Ocorre que, para constituírem reservas em dólar - um imperativo do equilíbrio financeiro no mundo contemporâneo -, os países periféricos necessitam adquirir títulos da dívida pública dos Estados Unidos. Esses títulos, como quaisquer outros, são promessas de pagamento. No entanto, diferentemente dos outros, nunca são pagos, uma vez que a necessidade constante de reservas em dólares dos demais países faz com que seja sempre necessário que novos títulos sejam gerados (troca-se, assim, títulos antigos por títulos novos).

Espera-se que esses títulos, como todos os títulos, vençam e sejam pagos, eventualmente, mas
como o economista Michael Hudson - o primeiro a observar isso no início dos anos 1970 - notou,
essas obrigações nunca serão cumpridas: "uma vez que esses títulos do Tesouro estão sendo
constituídos no interior da base monetária global, eles não terão que ser pagos, pois serão rolados
indefinidamente; essa ferramenta é a essência da aventura financeira dos Estados Unidos, um
imposto aplicado às custas de todo o globo". E tem mais: com o tempo, o efeito combinado das
baixas taxas de juros [norte-americanas] e da inflação é que esses títulos na verdade têm seu valor
depreciado (...). Os economistas preferem chamar isso de seigniorage. O efeito, no entanto, é o
de que o poder imperial dos Estados Unidos é baseado em uma dívida que nunca poderá ser paga.
Sua dívida pública se tornou uma promessa, não apenas em relação ao seu próprio povo, mas 
também em relação às nações de todo o mundo, que todos sabem que não será nunca tangível. (GRAEBER, 2011, p. 366-367)

Assim, o princípio moral de que as dívidas devem ser pagas vale apenas para os outros não por acaso, a denominação econômica para tal evento remete a uma medieval senhoriagem. E aqui reside o ponto nevrálgico da regulação jurídica de tal endividamento: os títulos da dívida pública norte-americana (e também da dívida alemã, que exerce do lado europeu do Atlântico uma significativa parcela de poder imperial) não possuem - e não precisam mesmo ter - uma cláusula de renúncia de jurisdição ou de inaplicabilidade das leis locais. A dívida dos Estados Unidos é inquestionável, porque a necessidade que se impõe é a de financiamento dos países periféricos por meio da rolagem dessa dívida norte-americana, a qual não precisa ser paga. Por outro lado, à dívida da Argentina, aplica-se a teologia jurídica das obrigações: ou se paga a dívida, ou não prevalece o poder soberano.

Neste mundo, "pagar a dívida" pode muito bem parecer a perfeita definição da moralidade, justamente porque muita gente paga as suas dívidas. Por exemplo, tornou-se frequente, em muitas empresas nos Estados Unidos, que, diante de uma dívida, elas simplesmente esperassem para ver o que acontecia se não pagassem (...). Em outras palavras, o princípio da honra foi, desse modo, quase completamente removido do mercado. Como resultado, toda a matéria da dívida se tornou rodeada por uma aura de religião. Na verdade, pode-se até mesmo dizer que há uma dupla teologia, uma para os credores, e uma para os devedores (GRAEBER, 2011, p. 377).

Essa se torna uma expressão cristalina do que se pode denominar um imperialismo da dívida, a minar o jus imperii dos países periféricos, como a Argentina, bem como sua colocação na qualidade de par inter pares. A constituição da dívida - imperativa no contexto contemporâneo do capitalismo - tem como pré-condição a abdicação da soberania. E a Argentina o fez mediante atos de gestão, decretos que terminam por sobrepujar a necessidade essencialmente política de se eleger a norma aplicável a uma dada situação de fato e que são afirmados, ao fim e ao cabo, pela força eminentemente insculpida em uma percepção kantiana do constitucionalismo - do direito obrigacional de um ordenamento-suserano. 


\section{CONCLUSÃO}

De todo modo, o que é uma dívida? Uma dívida é somente a perversão de uma promessa. É uma promessa corrompida pela matemática e pela violência. Se a liberdade (a liberdade real) é a possibilidade de fazer amigos, então ela é também, necessariamente, a possibilidade de fazer promessas factíveis. Que tipos de promessas homens e mulheres genuinamente livres fazem uns para os outros? No atual momento, não podemos nem mesmo dizer. Trata-se mais de uma questão de saber como podemos chegar a um ponto que nos permita encontrar. E o primeiro passo nessa jornada, na verdade, é aceitar que, em um sentido amplo, do mesmo modo como ninguém tem o direito de nos dizer nosso real valor, ninguém tem o direito de nos dizer quanto nós realmente devemos.

— David Graeber (GRAEBER, 2011, p. 391, tradução livre)

Em 20 de junho de 2007, o então Secretário do Tesouro dos Estados Unidos da América, Henry Paulson, apresentou-se perante o Congresso daquele país para uma sessão da Comissão de Serviços Financeiros da Câmara dos Deputados estadunidense. Durante a sessão, promovida anualmente para discutir a situação das finanças nacionais, a conjuntura econômica e seus efeitos sobre o Tesouro norte-americano, um questionamento chamou a atenção. Ele foi feito pela Deputada de Wisconsin, representante do Partido Democrata na comissão, Gwen Moore.

A deputada, envolvida com pautas relativas a matérias humanitárias no continente africano, fez uma questão ao Secretário do Tesouro a respeito da atuação dos fundos abutres. Questionou o porquê de os Estados Unidos da América não fornecerem, aos países africanos, assistência técnica que permita, de algum modo, um enfrentamento da atuação de tais fundos. A resposta ríspida do Sr. Paulson, então, foi reveladora: "Nós estamos fazendo o que podemos para ajudá-los, e eu lamento o que os fundos abutres estão fazendo; nós usamos soluções morais. No entanto, os fundos abutres têm o Estado de direito ao seu lado" (PAULSON, 2007, tradução livre).

A deputada Moore insistiu no questionamento, enfatizando que os procedimentos dos fundos abutres e o incremento das dívidas públicas dos países não eram dotados da necessária transparência. A resposta foi imediata: "Não se trata de uma discussão sobre transparência. O direito basicamente diz que se você toma um empréstimo, você tem o dever de pagá-lo de volta" 
(PAULSON, 2007, tradução livre). Não satisfeita, Moore questionou se não seria o caso de se aplicar a doutrina das dívidas odiosas, tendo em vista a conversão para fins tidos como ilegítimos. Mas o tempo de sua intervenção acabou.

$\mathrm{O}$ rápido diálogo mencionado sintetizou alguns dos principais elementos que foram abordados neste trabalho. Em primeiro lugar, é preciso ter em mente que a questão do endividamento envolve, desde que existe uma organização econômica, um forte elemento moral, embora sua percepção tenha se modificado com o tempo. Se, nos tempos mais remotos, ter uma dívida implicava ter credibilidade e, portanto, disponibilidade de participação nos mercados, na atualidade, essa percepção foi radicalmente invertida. Ter uma dívida, em nossa sociedade constituída e movida pelo crédito, tornou-se, a um só tempo, um imperativo - porquanto constitui condição de acesso aos mercados pautados na centralidade do trabalho gerador de aumento dos lucros de uma pequena parcela financista - e um desabono.

Em segundo lugar, a relevância econômica adquirida pelas relações de crédito - que faz com que todos, ou quase todos, queiramos ser partes de um sistema financeiro garantidor de renda desvinculada da produção - levou à geração desmesurada de recursos financeiros, a qual resultou na conversão do produto do trabalho em papéis comercializados por um pequeno conglomerado de entidades financeiras.

Tal configuração afetou imensamente a estruturação do Estado. Se é verdade que os entes estatais, desde longa data, participaram de operações de crédito, é também certo que essas operações experimentaram giro substancial no contexto que sucedeu o fim da Segunda Guerra Mundial e se intensificou após a queda do padrão ouro. A dívida pública passou a ser o elemento fundamental de participação dos governos nos mercados financeiros. Mas essa participação não tem significado tomar parte desses mesmos mercados, mas submeter-se às condições impostas às necessidades dos monopólios financeiros globais.

Nesse novo contexto, marcado pela assunção do neoliberalismo e pelas suas tentativas de defender uma socialização das finanças - e é curioso que a sociedade somente exista como tal no momento de fazer sobre as atuais e futuras gerações o peso moral do endividamento -, direitos políticos tornam-se antivalores econômicos. Assim, enquanto o Estado emite dívida, assume taxas de juros extorsivas nos mercados globais por meio de atos de gestão financeira ou abdica da aplicação de suas próprias leis na apreciação dos instrumentos de crédito, os próceres das finanças globais não enxergam grandes problemas. No entanto, quando a força do contexto impõe uma 
gestão preocupada com direitos que escapam à construção da liberdade estrita de mercado, não tardam a aparecer as mãos pesadas da aritmética e da violência institucional para obstar os parcos mecanismos de governo existentes para controlar a voracidade da conformação global dos juros.

Integrando populações inteiras ao mercado de crédito, o mundo das finanças submeteu as primeiras aos ditames morais do segundo. A compreensão dos teóricos neoliberais consiste, como já se mencionou, em uma releitura da tese liberal clássica de acordo com a qual sempre se governa demais. Essa releitura se fez a partir da concepção de um binômio expresso por Milton Friedman e apreendido com perspicácia por Atílio Borón (BORÓN, 2003). Em uma de suas obras de maior relevância, Friedman evidenciou sua leitura sobre a liberdade, apreendida em termos estritamente econômicos, e sobre os modos como ela deve ser articulada em termos de "cooperação" social:

O problema básico da organização social é como coordenar as atividades econômicas de um grande número de pessoas. Mesmo em sociedades relativamente atrasadas, a divisão extensiva do trabalho e a especialização das funções é necessária para tornar efetivo o uso dos recursos disponíveis. Nas sociedades avançadas, a escala na qual a coordenação é necessária, para se aproveitarem inteiramente as oportunidades oferecidas pela ciência e pela tecnologia modernas, é enormemente maior. Literalmente milhões de pessoas estão envolvidas no processo de dar o pão de cada dia umas às outras, sem falar da produção dos automóveis do ano. $\mathrm{O}$ desafio para quem crê na liberdade é reconciliar a interdependência generalizada com a liberdade individual. Fundamentalmente, há dois modos de coordenar as atividades econômicas de milhões. Um é o dirigismo central envolvendo o uso da coerção - a técnica das forças armadas e do Estado totalitário moderno. A outra é a cooperação voluntária de indivíduos - a técnica do mercado. (FRIEDMAN, 1962, p. 12-13, tradução livre)

Como se depreende do trecho transcrito, Friedman entende que a articulação entre a interdependência das pessoas e a liberdade individual somente pode ser mediada de duas formas: por meio do dirigismo central estatal ou por meio da cooperação voluntária entre indivíduos considerados no interior de um mercado. A segunda via, evidentemente a opção deontológica feita por Friedman, é por ele compreendida como consequência da "elementar - embora frequentemente rejeitada - proposição segundo a qual ambas as partes em uma transação econômica se beneficiam dela, desde que seja bilateralmente informada e voluntária" (FRIEDMAN, 1962, p. 13, tradução livre). Atilio Borón bem percebeu que se trata de um modo de perceber a realidade a partir de duas opções definidas de modo estanque: ou se opta pela via política do Estado ou pela via livre, extrapolítica, do mercado (BORÓN, 2003). Em outros termos, fora do modelo de uma sociedade de empreendedores livres, o que resta é o vazio autoritário da política - política e economia tornamse domínios inconciliáveis de reprodução social.

Com esse esvaziamento do sentido político da economia e a hegemonia do pensamento neoliberal a partir da década de 1970, os mercados - em especial os mercados financeiros - 
terminam por sujeitar completamente a operatividade política, forjando um discurso de fim das soberanias a partir da ideia de que a boa governança, embasada em parâmetros técnicos dominados por uma intelligentsia do campo econômico, é o que pode conduzir as sociedades a patamares superiores de liberdade.

O discurso da horizontalidade e do esvaziamento político da economia chegou ao campo do endividamento público. A contração de dívidas é vista não como uma necessidade imposta pelas finanças globais para sustentar os Estados, mas como um ato deliberado dos agentes de governo que passam a se vincular, inexoravelmente, aos termos e às condições postas no momento da assinatura dos contratos. E aqui reside o ponto central do capital portador de juros cobrados dos Estados nacionais: a tese contratualista se torna, também no endividamento público, avalista do elemento fundante daquilo que, no futuro, garante a perpetuação de uma relação de dominação inicial. É a assinatura do contrato de endividamento que, como em qualquer documento fundante, dá o crédito a si mesma, demandando a força do direito, funda esse próprio direito - um direito de crédito, voltado ao futuro, sustentado por um jogo conceitual de bases morais segundo o qual as dívidas devem ser pagas.

Esse jogo termina por velar a assunção de uma nova modalidade de imperialismo, que guarda algumas semelhanças com a forma já diagnosticada por Lênin em seu seminal escrito $O$ imperialismo, etapa superior do capitalismo. Naquela obra, Lênin identificara, como características centrais do imperialismo: (1) a monopolização da produção; (2) a fusão entre capital financeiro especulativo e capital produtivo; (3) a sobreposição da exportação de capitais à exportação de mercadorias; (4) a consolidação de alianças capitalistas supranacionais; e (5) o fim da partilha territorial do mundo entre as potências capitalistas (LENIN, 2011, p. 218). A emergência do neoliberalismo global e a universalização das relações de crédito levou a um contexto no qual "generaliza-se a suposição de que a universalidade constitua uma ideia ou um princípio geral, com teor moralizante", que "expressaria apenas os objetivos da dominação, a qual a utilizaria como uma mitologia legitimadora" (FONTES, 2008, p. 104-105).

Especificamente a respeito do endividamento público, esse universalismo implicou que as possibilidades de controle soberano pelos países periféricos - conquanto não sejam os únicos endividados - restaram completamente esvaídas, justamente em razão do esvaziamento político do conteúdo decisório em matéria de política econômica, respaldado pela premissa moral subjacente ao mercado da dívida. E isso se deu, sobretudo, por meio da escolha dos foros de aplicação do 
direito que regula essa dívida. Ao abdicarem da atividade legiferante sobre suas relações creditícias, os Estados subdesenvolvidos não tiveram outra saída que não apelar a uma exceção. $\mathrm{O}$ estado de emergência, no entanto, somente pode ser operado se um poder soberano pode decidir sobre ele. Se o poder soberano está fora do Estado devedor, a relação que se tem estabelecida é de dominação, de suserania, de senhoriagem, jamais de independência ou de equidade.

Apontar soluções para a questão da especulação em torno das dívidas dos países subdesenvolvidos não era objetivo deste trabalho. Mas, se houver alguma, esta pesquisa parece indicar que ela passa por duas etapas essenciais. A primeira consiste no diagnóstico de que os sistemas de direito atualmente existentes foram forjados para conduzir a interpretações prejudiciais aos credores, especialmente por meio das cláusulas de renúncia de soberania presentes nos instrumentos de endividamento. A segunda aponta no sentido de que outra etapa das relações de crédito não será possível enquanto vigorar o preceito moral sintetizador do capitalismo de base financeira, segundo o qual todas as dívidas devem ser pagas. Ao fim e ao cabo, esse princípio moral somente é aplicável àqueles que ocupam a posição de sujeição jurídica em relação a quem controla o sistema de crédito - a quem é dado, no final das contas, emitir suas dívidas com a garantia de que não serão saldadas. 


\section{REFERÊNCIAS BIBLIOGRÁFICAS}

ADORNO, T.; HORKHEIMER, M. Dialética do esclarecimento. Trad. Guido Antonio de Almeida. Rio de Janeiro: Zahar, 1985.

AGAMBEN, G. Homo sacer - o poder soberano e a vida nua I. Trad. Henrique Burigo. Belo Horizonte: Editora UFMG, 2007.

AGAMBEN, G. Estado de Exceção. Trad. Iraci D. Poletti. São Paulo: Boitempo, 2011.

AGAMBEN, G. O que é o contemporâneo? E outros ensaios. Chapecó: Argos, 2013.

AGAMBEN, G. What is a destituent power? Environment and planning: society and space, $v$. 32, n. 1, p. 65-74, 2014.

ANTUNES, R. Os sentidos do trabalho: ensaios sobre a afirmação e a negação do trabalho. São Paulo: Boitempo, 2003.

BARDIN, L. Análise de Conteúdo. Lisboa: Edições 70, 1977.

BENAKOUCHE, R. Bazar da dívida externa brasileira. São Paulo: Boitempo, 2013.

BENJAMIN, W. Para uma crítica da violência. In: Escritos sobre mito e linguagem (1915-1921). São Paulo: Editora 34, 2013. p. 121-156.

BIN, D. Dívida pública, classes e democracia no Brasil pós-real. Tese de Doutorado. Departamento de Sociologia. Universidade de Brasília (UnB), 2010.

BODIN, J. Los seis libros de la República. Trad. Pedro Bravo Gala. Madrid: Editorial Tecnos, 1997.

BOHOSLAVSKY, J. P.; TORELLY, M. Cumplicidade financeira na ditadura brasileira: implicações atuais. Revista Anistia Política e Justiça de Transição, v. 6, p. 70-117, 2012.

BORÓN, A. Estado, capitalismo y democracia en America Latina. Buenos Aires: Clacso, 2003.

BRUNKHORST, H. Alguns problemas conceituais e estruturais do cosmopolitismo global. Revista Brasileira de Ciências Sociais, v. 26, p. 7-38, 2011.

BRUNKHORST, H. A decapitação do legislador: a crise europeia - paradoxos da constitucionalização do capitalismo democrático. Direito.UnB, v. 1, n. 1, p. 93-118, 2014.

BUNDESVERFASSUNGSGERICHT. 2 BvM 1-5/03, 1, 2/06. Alemanha, 2007.

BUTLER, J. Precarious life - the powers of mourning and violence. Londres: Verso, 2006. 
CARCANHOLO, R.; NAKATANI, P. O capital especulativo parasitário: uma precisão teórica sobre o capital financeiro, característico da globalização. Ensaios EFE, v. 20, n. 1, p. 284-304, 1999.

CARVALHO NETTO, M. DE. Hermenêutica constitucional spb o paradigma do Estado Democrático de Direito. In: Jurisdição e hermenêutica constitucional no Estado Democrático de Direito. Belo Horizonte: Mandamentos, 2004. p. 25-44.

CHESNAIS, F. Mundialização : o capital financeiro. Revista Outubro, p. 7-28, 2001.

COMISSÃO DE DIREITO INTERNACIONAL. Fragmentation of International Law: difficulties arising from the diversification and expansion of International Law (Report of the study group of the ILC, finalized by MartiiKoskenniemi). Disponível em: $<$ http://untreaty.un.org/ilc/documentation/english/a_cn4_1682.pdf $>$.

CONDE, R. C. La crisis argentina de 2001-2002. Disponível em: $<$ http://www.scielo.cl/scielo.php?script=sci_arttext\&pid=S0717-

68212003012100049\&lng=es\&nrm=iso>. Acesso em: 3 dez. 2014.

CONSTANT, B. Da liberdade dos antigos comparada à dos modernos.

CORTE SUPREMA DI CASSAZIONE. Ordinanza n. 6532 - Luca Borri v. Repubblica ArgentinaItália, 2005.

COSTA, A. A. O poder constituinte e o paradoxo da soberania limitada. Teoria \& Sociedade, v. 19, n. 1, p. 198-227, 2011.

COSTA, A. B. Poder constituinte no Estado Democrático de Direito. Veredas do Direito, v. 3, n. 5, p. 31-45, 2006.

COUTINHO, L.; BELLUZZO, L. G. "Financeirização" da riqueza, inflação de ativos e decisões de gasto em economias abertas. Economia e Sociedade, v. 11, p. 137-150, 1998.

DAMILL, M.; FRENKEL, R.; RAPETTI, M. The Argentinean debt: history, default and restructuring. EconomiA, v. 6, n. 3, p. 29-90, 2005.

DE ROTA, A. F. Deus ex machina. Madrid: Melusina, 2014.

DELEUZE, G. Conversações (1972-1990). Trad. Peter Pal Pelbart. São Paulo: Editora 34, 1992.

DELEUZE, G.; GUATTARI, F. Preface. In: Anti-Oedipus. Minneapolis: University of Minnesota Press, 1977. p. XI-XIV.

DORNBUSCH, R. As dívidas dos países em desenvolvimento. Revista de Economia Política, v. 8, n. 1, p. 14-49, 1988. 
DREITZEL, H. P. Ação racional e orientação política. In: DREITZEL, H. P. et al. (Eds.). . Tecnocracia e ideologia. Rio de Janeiro: Tempo Brasileiro, 1975. p. 11-47.

FARIA, J. E. O direito na economia globalizada. São Paulo: Malheiros, 2004.

FATTORELLI, M. L. Manual para realizar auditorías de la deuda del tercer mundo. Genebra: CETIM/CADTM, 2006.

FERGUSON, A. Essay on the history of civil society. Londres: T Cadell, 1787.

FERRAZ JR., T. S. A ciência do direito. São Paulo: Atlas, 1980.

FERREIRA, B. O risco do político: crítica ao liberalismo e teoria política no pensamento de Carl Schmitt. Belo Horizonte: Editora UFMG, 2004.

FERREIRA, B. O essencial e o acidental: Bodin (e Hobbes) e a invenção do conceito moderno de constituição. Lua Nova, v. 88, p. 381-426, 2013.

FISCHER-LESCANO, A. Deudas odiosas y el derecho mundial. Direito GV, v. 1, n. 11, p. $23-$ 40, 2005.

FONTES, V. O imperialismo: de Lenin aos dias atuais. Outubro, v. 17, n. 1, p. 69-108, 2008.

FONTEVECCHIA, A. The Real Story Of How A Hedge Fund Detained A Vessel In Ghana And Even Went For Argentina's “Air Force One”. Forbes, maio 2012.

FOUCAULT, M. Microfísica do Poder. Rio de Janeiro: Graal, 1979.

FOUCAULT, M. Vigiar e punir - história da violência nas prisões. Trad. Raquel Ramalhete. Petrópolis: Vozes, 1987.

FOUCAULT, M. Em defesa da sociedade. Trad. Maria Ermantina Galvão. São Paulo: Martins Fontes, 1999.

FOUCAULT, M. Estratégia, poder-saber. São Paulo: Forense, 2005.

FOUCAULT, M. Nascimento da Biopolitica. Trad. Eduardo Brandão. São Paulo: Martins Fontes, 2008a.

FOUCAULT, M. Segurança, território, população. Trad. Eduardo Brandão; Claudia Berliner. São Paulo: Martins Fontes, 2008b.

FOUCAULT, M. A verdade e as formas jurídicas. Trad. Roberto Cabral de Melo Machado; Eduardo Jardim Morais. 3. ed. Rio de Janeiro: Nau Editora, 2008c. 
FOUCAULT, M. História da sexualidade I: a vontade de saber. Trad. Maria Thereza da Costa Albuquerque. Rio de Janeiro: Paz e Terra, 2014.

FRIEDMAN, M. Capitalism and freedom. Chicago: University of Chicago Press, 1962.

FUNDO MONETÁRIO INTERNACIONAL. A Survey of Experiences with Emerging Market Sovereign Debt Restructurings. Disponível em: $<$ http://www.imf.org/external/np/pp/eng/2012/060512.pdf $>$.

GALASSO, N. De la banca Baring al FMI: historia de la deuda externa argentina. Buenos Aires: Editorial Colihue, 2003.

GRAEBER, D. Debt - the first 5,000 years. New York: Melville House Publishing, 2011.

GRIESA, T. F. NML Capital Ltd. v. Republic of Argentina, 2012.

HABERMAS, J. A crise de legitimação no capitalismo tardio. Trad. Vamireh Chacon. Rio de Janeiro: Tempo Brasileiro, 1980.

HABERMAS, J. A nova intransparência - a crise do Estado de bem-estar social e o esgotamento das energias utópicas. Novos Estudos, n. 18, p. 103-114, 1987.

HABERMAS, J. Direito e democracia: entre facticidade e validade. Trad. Flavio Beno Siebeneichler. Rio de Janeiro: Tempo Brasileiro, 2003.

HABERMAS, J. A inclusão do outro: ensaios de teoria política. Trad. George Sperber; Paulo Astor Soethe; Milton Camargo Mota. São Paulo: Loyola, 2007.

HABERMAS, J. Plea for a constitutionalization of international law. XXIII World Congress of Philosophy - Philosophy as inquiry and way of life, 2013.

HABERMAS, J. No turbilhão da tecnocracia: um apelo por solidariedade europeia. Direito.UnB, v. 1, n. 2, 2014.

HARDT, M.; NEGRI, A. Imperio. Trad. Berilo Vargas. São Paulo: Record, 2000.

HARVEY, D. O enigma do capital e as crises do capitalismo. Trad. João Alexandre Peschanski. São Paulo: Boitempo, 2011.

HARVEY, D. A condição pós-moderna. Trad. Adail Ubirajara Sobral; Maria Stela Gonçalves. São Paulo: Loyola, 2012.

HARVEY, D. O novo imperialismo. Trad. Adail Sobral; Maria Stela Gonçalves. São Paulo: Loyola, 2013. 
HOBBES, T. Leviatã ou matéria, forma e poder de uma república eclesiástica e civil. Trad. João Paulo Monteiro; Maria Beatriz Nizza Da Silva. Disponível em: http://www.dhnet.org.br/direitos/anthist/marcos/hdh_thomas_hobbes_leviatan.pdf.

KAHN, P. W. The Question of Sovereignty. Stanford Journal of International Law, v. 40, p. 259-282, 2004.

KANT, I. À paz perpétua. Trad. Marco Zingano. São Paulo: L\&PM, 2008.

KANTOROWICZ, E. H. Os dois corpos do rei - um estudo sobre a teologia política medieval. Trad. Cid Knipel Moreira. São Paulo: Companhia das Letras, 1998.

KELSEN, H. A democracia. São Paulo: Martins Fontes, 2000.

KELSEN, H. Teoria pura do direito. Trad. João Baptista Machado. São Paulo: Martins Fontes, 2006.

KOSKENNIEMI, M. Constitutionalism as mindset: reflections on Kantian themes about International Law and globalization. Theoretical inquiries in Law, v. 8, n. 1, p. 9-36, 2007.

KOSKENNIEMI, M.; LEINO, P. Fragmentation of International Law? Postmodern anxieties. Leiden Journal of International Law1, v. 15, n. 3, p. 553-579, 2002.

LACLAU, E. On populist reason. Londres: Verso, 2007.

LENIN, V. I. O imperialismo, etapa superior do capitalismo. Campinas: Unicamp, 2011.

LOPES, J. G. Auditoria da dívida pública sob a dimensão do direito à memória e à verdade contribuições a partir da (e para a) ADPF n. 59. Monografia de Conclusão de Curso. Faculdade de Direito. Universidade de Brasília, 2013.

LOSURDO, D. Liberalism: a counter-history. Trad. Gregory Eliott. Londres: Verso, 2014.

LUHMANN, N. A constituição como aquisição evolutiva. Rechthistorisches Journal, v. IX, p. 176-220, 1990.

MANKIW, N. G. Introdução à Economia. Trad. Allan Vidigal Hastings. São Paulo: Cangage Learning, 2009.

MANZO, A. G.; SALVA, C. G. La crisis del neoliberalismo en Argentina. Una mirada retrospectiva sobre las causas del default 2001: buscando razones para entender el quiebre de nuestro país y con el FMI. Passagens. Revista Internacional de História Política e Cultura Jurídica, v. 4, n. 2, p. 299-327, 2012.

MARTINEAU, A.-C. The rhetoric of fragmentation: fear and faith in International Law. Leiden Journal of International Law, v. 22, p. 1-28, 2009. 
MARX, K. Capital - a critique of political economy. Trad. Ben Fowkes. Londres: Penguin Books, 1976.

MASCARO, A. L. Estado e forma política. São Paulo: Boitempo, 2013.

MATTEI, U.; NADER, L. Plunder - when the rule of law is illegal. Malden: Blackwell, 2008.

MEZZANZANICA, M. Dai due corpi dal re al corpo assoggettato. Kantorowicz, Foucault e il corpo politico. Metabasis.it - Filosofia e comunicazione, v. VI, n. 12, p. 1-23, 2011.

MICHALOWSKI, S. Unconstitutional regimes of validity of sovereign debt. In: Hampshire: Ashgate, 2007.

MICHALOWSKI, S. Sovereign Debt and Social Rights-Legal Reflections on a Difficult Relationship. Human Rights Law Review, v. 8, n. 1, p. 35-68, 10 jan. 2008.

MOUFFE, C. The democratic paradox. Londres: Verso, 2000.

MUSE-FISHER, J. Starving the vultures: NML Capital v. Republic of Argentina and solutions to the problem of distressed-debt funds. California Law Review, v. 102, p. 1671-1725, 2014.

NEGRI, A. O poder constituinte - ensaio sobre as alternativas da modernidade. Trad. Adriano Pilatti. Rio de Janeiro: DP\&A, 2002.

NEIBURG, F. Inflación y crisis nacional. Culturas económicas y espacios públicos en Argentina y Brasil. Anuario de Estudios Americanos, v. 62, n. 1, p. 113-138, 2005.

NEVES, A. C. A crise actual da filosofia do direito no contexto da crise global da filosofia tópicos para a possibilidade de uma reflexiva reabilitação. Coimbra: Coimbra Editora, 2003.

NEVES, M. Transconstitucionalismo. São Paulo: Martins Fontes, 2009.

OFFE, C. O dilema político da tecnocracia. In: DREITZEL, H. P. et al. (Eds.). . Tecnocracia e ideologia. Rio de Janeiro: Tempo Brasileiro, 1975. p. 70-84.

OFFE, C. Contradictions of the welfare state. Londres: Hutchinson, 1984.

ORGANIZAÇÃO DAS NAÇÕES UNIDAS. Reports of international arbitral awards - recueil des sentences arbitrales, v. XXIII. New York: ONU, 2004.

ORGANIZAÇÃO DAS NAÇÕES UNIDAS. Argentina v. Ghana - The ARA Libertad Case, 2012.

PACHUKANIS, E. Teoria geral do direito e do marxismo. São Paulo: Editora Acadêmica, 1988. 
PAULSON, H. The state of the international financial systemWashington, D.C.National Congress, , 2007. Disponível em: <http://www.gpo.gov/fdsys/pkg/CHRG110hhrg37558/html/CHRG-110hhrg37558.htm>

QUEIROZ, M. V. L. Ernesto Laclau e teoria do discurso: aproximações entre direito e estratégia política. [s.l.] Universidade de Brasília, 2013.

REPÚBLICA ARGENTINA. Prospectus. Washington, D.C.: Supreme Court, 2014.

RIBEIRO, R. J. Ao leitor sem medo - Hobbes escrevendo contra o seu tempo. Belo Horizonte: Editora UFMG, 2004.

ROPOHL, G. Análise da discussão alemã sobre a tecnocracia. In: DREITZEL, H. P. et al. (Eds.). . Tecnocracia e ideologia. Rio de Janeiro: Tempo Brasileiro, 1975. p. 48-69.

ROUSSEAU, J.-J. Do contrato social. Trad. Pietro Nassetti. São Paulo: Martin Claret, 2007.

RYAN, A. Hobbes's political philosophy. In: SORELL, T. (Ed.). . The Cambridge Companion to Hobbes. Cambridge: Cambridge University Press, 1996. p. 208-245.

SACK, A. Les effets des transformations des Etats sur leurs dettes publiques et autres obligations financiers. Paris: Recueil Sirey, 1927.

SAMTLEBEN, J. Cláusulas de jurisdicción y legislación aplicable en los contratos de endeudamiento externo de los Estados Latinoamericanos. Revista de Informação Legislativa, v. 26, n. 101, 1989.

SCHLEMMER-SCHULTE, S. Fragmentation of International Law: the case of International Finance \& Investment Law versus Human Rights Law. Pacific McGeorge Global Business \& Development Law, v. 25, p. 409-424, 2012.

SCHMITT, C. Teologia política. Trad. Elisete Antoniuk. Belo Horizonte: Del Rey, 2006.

SCHMITT, C. O conceito do político - Teoria do partisan. Trad. Geraldo De Carvalho. Belo Horizonte: Del Rey, 2008.

SCHUBERT, M. F. When vultures attack - balancing the right to immunity against reckless sovereigns. Brooklyn Law Review, v. 78, n. 3, p. 1097-1129, 2013.

SIEYÈS, E. J. A constituinte burguesa: qu'est-ce que le Tiers État? Trad. Norma Azevedo. Rio de Janeiro: Lumen Juris, 2001.

STURZENEGGER, F.; ZETTELMEYER, J. Debt default and lessons of a decade of crisis. Cambridge: MIT Press, 2006. 
SUPREME COURT OF THE UNITED STATES. Republic of Argentina v. NML Capital Ltd., 2014.

TEUBNER, G. A Bukowina global sobre a emergência de um pluralismo jurídico transnacional. Impulso, v. 14, n. 33, p. 9-31, 2003.

THEODORO FILHO, W. R. O abandono da Constituição: soberania e poder judiciário no paradigma biopolítico. Tese de Doutorado. Faculdade de Direito. Universidade de Brasília, 2011.

TULLY, J. Modern constitutional democracy and imperialism. Osgood Hall Law Journal, v. 46, n. 3, p. 461-493, 2008.

WACQUANT, L. A tempestade global da lei e ordem: sobre punição e neoliberalismo. Revista de Sociologia e Política, v. 20, n. 41, p. 7-20, 2012.

WAIBEL, M. Sovereign defaults before international courts and tribunals. Cambridge: Cambridge University Press, 2011.

WARAT, L. A. Saber crítico e senso comum teórico dos juristas. Sequência, v. 3, n. 5, p. 48-57, 1982.

WEBER, G. (coord.). Sobre la deuda ilegítima - aportes al debate. Quito: Ciudad, 2003.

WEBER, M. Coleção “Os Pensadores” - História geral da economia. São Paulo: Abril Cultural, 1980.

WEISBROT, M.; SANDOVAL, L. Argentina's economic recovery - policy choices and implications. Washington, D.C.: CEPR. Disponível em: $<\mathrm{http}: / / w w w . c e p r . n e t / d o c u m e n t s /$ publications/argentina_recovery_2007_10.pdf $>$.

WILKINS, D. American Indian sovereignty and the U.S. Supreme Court: the masking justice. Austin: University of Texas Press, 1997.

WILKINS, D. American Indian politics and the American political system. Oxford: Rowman \& Littlefield Publishers, 2007. 